\title{
Palynological zonation and stratigraphy of the Jurassic section in the Gassum No. 1-borehole, Denmark.
}

BY

KAREN DYBKJAER

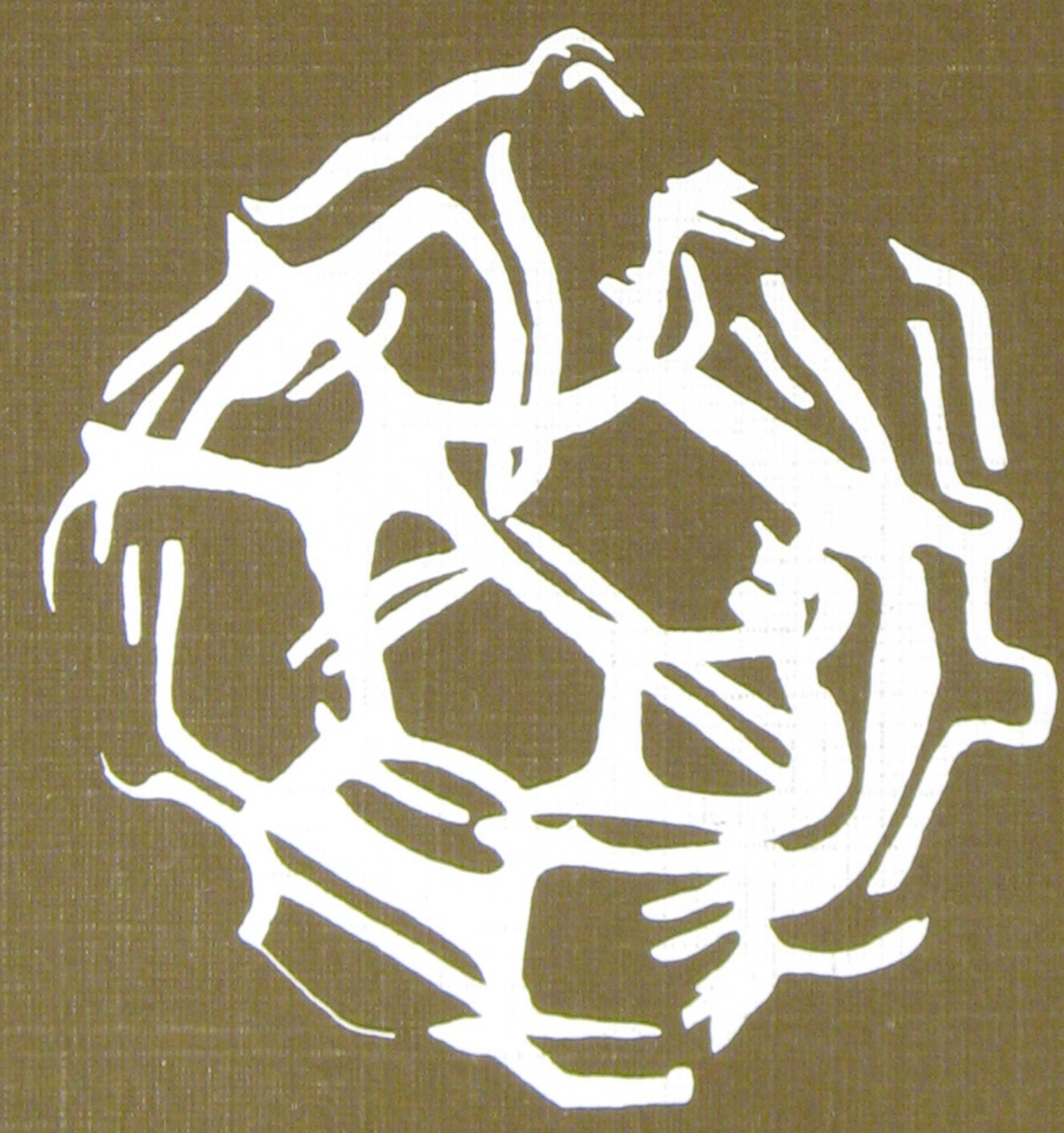

I kommission hos C. A. Reitzels forlag · København 1988 


\section{Palynological zonation and stratigraphy of the Jurassic section in the Gassum No. 1-borehole, Denmark.}

BY

KAREN DYBKJÆR

I kommission hos C. A. Reitzels forlag · København 1988 
Key words:

Biostratigraphy, palynomorphs, Jurassic, Denmark, the Danish Subbasin, sea-level changes.

With 14 plates and 1 range-chart

Vignet:

Lycopodiumsporites clavatoides

DGU Serie A nr. 21

ISBN 87-421-0755-5

ISSN 0901-0270

Oplag: 1000

Tryk: AiO Tryk as, Odense

Tegning: Lis Olesen, Lissie Jans

Dato: 1-9-1988

Karen Dybkjær,

Geological Institute, University of Aarhus,

DK-8000 Århus C, Denmark.

Redaktion: Leif Banke Rasmussen

(C) Danmarks Geologiske Undersøgelse,

Thoravej 31, DK-2400 København NV 


\section{Contents}

Abstract $\ldots \ldots \ldots \ldots \ldots \ldots \ldots \ldots \ldots \ldots \ldots$

Introduction $\ldots \ldots \ldots \ldots \ldots \ldots \ldots \ldots \ldots \ldots$

Geological setting ............... 6

Lithology and lithostratigraphy ......... 6

Bio- and chronostratigraphy ........... 7

Position of chronostratigraphical boundaries... 8

Materials and methods................ 9

Sampling .................. 9

Palynological preparation $\ldots \ldots \ldots \ldots \ldots \ldots 9$

Microscopical examination ............. 9

Palynomorph recovery ............... 10

Systematic section . . . . . . . . . . . . 11

Spores and pollen $\ldots \ldots \ldots \ldots \ldots \ldots \ldots \ldots \ldots 11$

Aquatic palynomorphs.............. 26
Palynostratigraphy ...................... 29

Definition of zones................ 29

Age of the zones................. 31

Age of the zones $\mathrm{D}$ and $\mathrm{E}$ based on

dinoflagellate cysts .............. 33

Stratigraphical conclusion ............ 35

Palaeoenvironment.................. 36

Eustatic sea-level changes reflected in the

distribution of palynomorphs . . . . . . . . 38

Acknowledgements................... 40

References ........................ 40

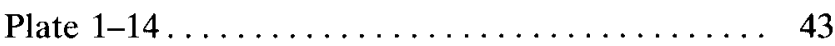

Index of species................ 72

Range-chart.............. inside back of cover 


\section{Abstract}

The Jurassic section of the Danish onshore borehole Gassum No. 1 has been investigated palynologically. 126 palynomorph-taxa have been recognized, consisting mainly of microspores and gymnosperm pollen. The palynomorphs are treated morphosystematically. 71 samples were prepared and the relative abundances determined in 32 representative samples. 5 spore- pollen zones, A to $E$, have been defined based on the stratigraphical ranges and abundances of specific taxa.
Correlating with data from Northwest Europe allows the zones to be dated as follows: Zone A: Late Rhaetian, Zone B: Hettangian, Zone C: Early Sinemurian to ?Pliensbachian/Toarcian, Zone D: Kimmeridgian/ Early Volgian, Zone E: Middle Volgian. The relative abundances of the main morphological groups of palynomorphs have been calculated and their stratigraphical variations correlated with previously proposed Early Jurassic sea-level changes. 


\section{Introduction}

The Gassum No. 1-borehole was one of the first deep borings to be drilled in the Danish area and is one of the most intensively investigated Danish on-shore boreholes. It was drilled by the Danish American Prospecting Company (DAPCo) from March 1948 to March 1951, terminating in Upper Permian strata at $3404 \mathrm{~m}$ below rotary table. The boring is situated on the flank of a deep-seated salt dome, the elevation of which was responsible for the present $5^{\circ}$ dip of the strata.
The Mesozoic sequence was cored at close, regular intervals and these cores have formed the basis for several palaeontological and lithological studies. Preliminary lithological descriptions of the core-material were carried out at the well-site and a bio-stratigraphic subdivision of the Mesozoic sediments was established on the basis of macrofossils, particularly ammonites (Frebold 1948, unpubl., Norwood, Nørvang \& von Elm 1951, unpubl., Gregersen \& Sorgenfrei 1951). A more detailed lithological study and a chronostratigraphic

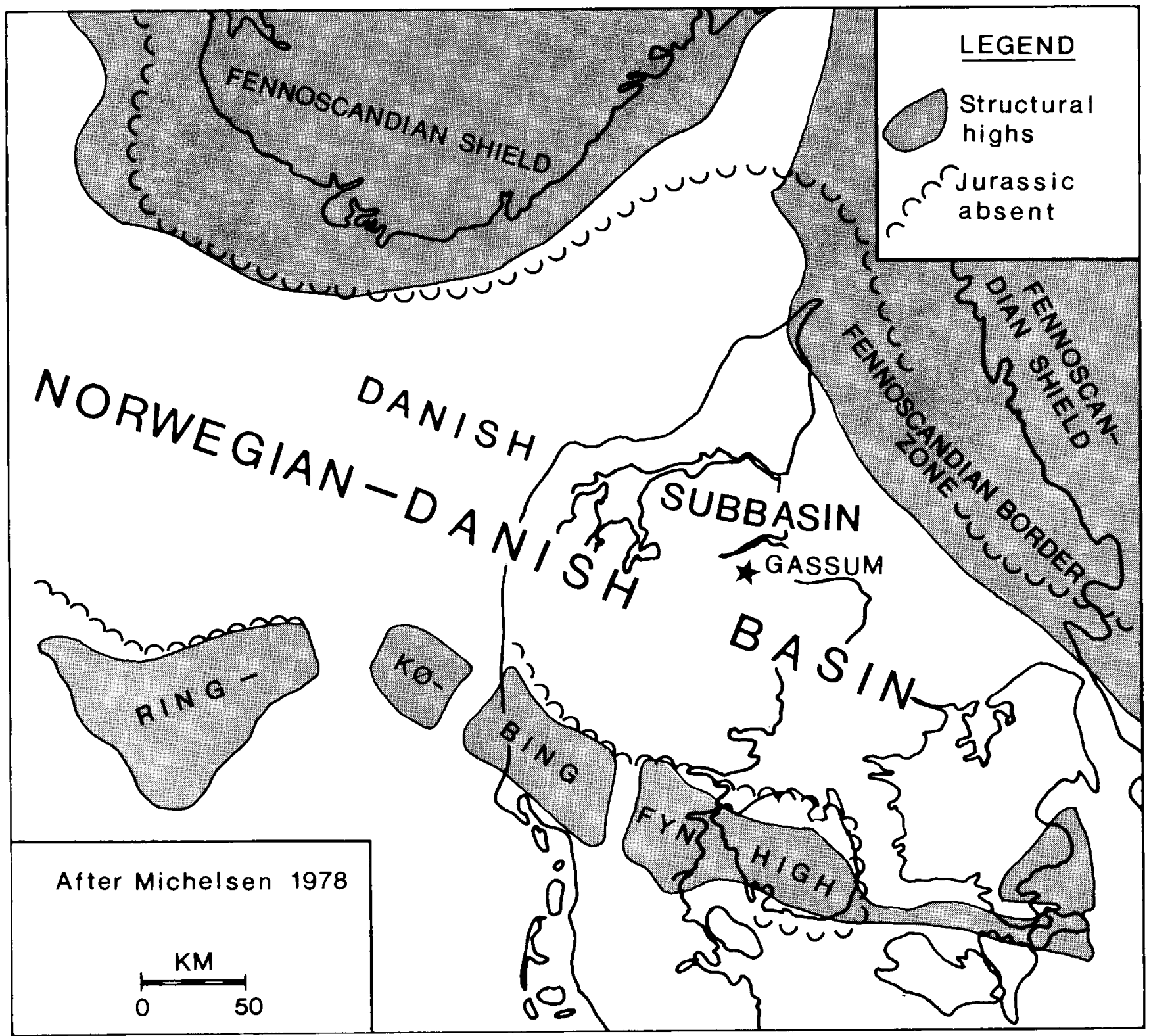

Figure 1. The main structural elements in the Danish area in the Jurassic Period and the location of the Gassum No. 1-borehole. 
subdivision was presented by Sorgenfrei \& Buch (1964). Larsen (1966) proposed a lithostratigraphic subdivision of the Jurassic sequence in the Danish Subbasin based partly on the core-material from the Gassum borehole. Biostratigraphical and palaeoecological studies of the core-material include investigations of Early Jurassic foraminiferal faunas (Nørvang 1957), Early Jurassic ostracod assemblages (Michelsen 1973, 1975), Triassic palynomorphs (Bertelsen 1978, Vasard Nielsen in prep.), and variations in the Early Jurassic bivalve fauna (Pedersen 1986).

The general objective of the present investigation has been to establish a biozonation of the Jurassic sequence from the Gassum No. 1-borehole, based on palynomorphs, and to correlate the sequence with palynologically investigated strata from north-western Europe.

\section{Geological setting}

The Gassum No. 1-borehole is situated in the central part of the Danish Subbasin (fig. 1). This subbasin comprises the eastern part of the larger NorwegianDanish Basin and persisted as a major area of subsidence from the Late Permian to the Late Cretaceous. It is separated from the North-German Basin to the south by the Ringkøbing-Fyn High and bounded to the north and east by the Fennoscandian Border Zone. The majority of the sediments deposited in the Danish Subbasin during the Triassic and Jurassic consist of clastic material (sand, silt and clay). Sediments were transported into the basin from the Fennoscandian Shield in the north and east with the result that the coarser clastics were deposited nearest the Fennoscandian Border Zone (Michelsen \& Bertelsen 1979).

The Fennoscandian Border Zone was tectonically activated during the Rhaetian (the "early Kimmerian phase"), and a renewed period of subsidence of the Danish Subbasin started. This local tectonism, combined with an eustatic sea-level rise, resulted in the deposition of a thick, deltaic to shallow marine sequence, known as the Gassum Formation (Bertelsen 1978, Ziegler 1982). During continued subsidence of the basin in the Early Jurassic a thick sequence of dark marine claystones was deposited, defined as the Fjerritslev Formation (Michelsen 1978). By the end of the Early Jurassic, and in the Middle Jurassic, the Ringkøbing-Fyn High was uplifted as a result of the "MidKimmerian tectonic phase" (Ziegler 1982). As a consequence, Upper Triassic to lower Upper Jurassic strata were eroded and are generally absent in large areas on the Ringk $ø$ bing-Fyn High and along its margins (Michelsen 1978, Michelsen \& Bertelsen 1979). During this time-interval the fluvial and deltaic sediments that comprise the Haldager Formation (Michelsen 1978) were deposited in the northern part of the basin. In the late Middle Jurassic and early Late Jurassic a second phase of subsidence was initiated which resulted in deposition of the marine claystones that comprise the Børglum Member (lower part of the Bream Formation) (Michelsen 1978). Brief uplift occurred at the JurassicCretaceous transition and the reduced water-depth resulted in deposition of the more coarse-grained Fredrikshavn Member (upper part of the Bream Formation) (Michelsen 1978). Subsidence then occurred throughout the Cretaceous, eventually including the Ringk øbing-Fyn High (Michelsen \& Bertelsen 1979).

In the Gassum No. 1-borehole the Gassum Formation is represented by $131 \mathrm{~m}$ of sediments, mainly limnic sandstones. The Mid-Kimmerian tectonic phase, combined with local salt-movements, has resulted in a hiatus comprising the uppermost Early Jurassic to the lowermost Late Jurassic (Norwood et al. 1951, unpubl., Sorgenfrei \& Buch 1964, Larsen 1966). Thus the $314 \mathrm{~m}$ of dark grey marine claystones, referred to the Fjerritslev Formation, are erosively overlain by sediments referred to the Bream Formation.

\section{Lithology and lithostratigraphy}

The lithology and general stratigraphy of the Gassum No. 1-borehole presented by Sorgenfrei \& Buch

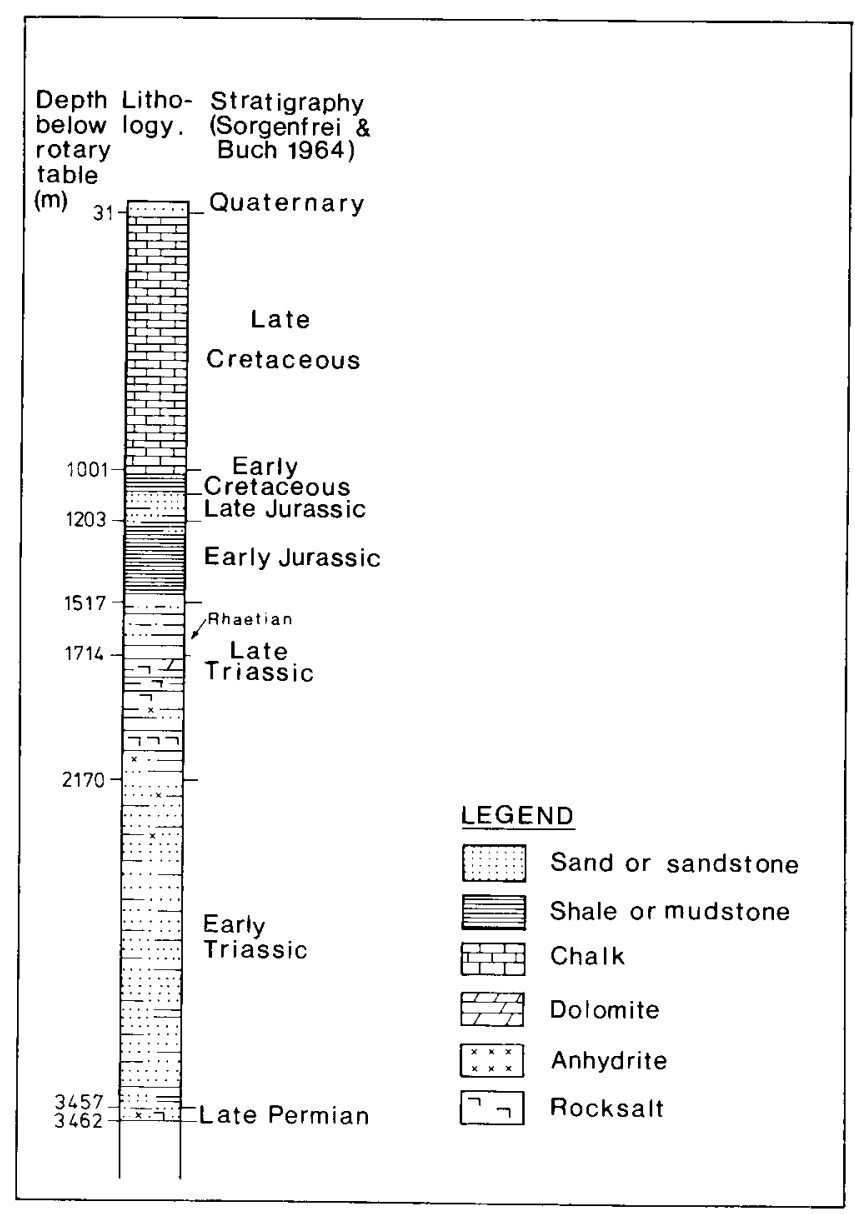

Figure 2. The entire sedimentary sequence of the Gassum No. 1-borehole. 
(1964), is shown in figure 2 . The more detailed subdivision of the Jurassic sequence, shown in figure 3 , is based partly on the subdivision by Sorgenfrei \& Buch (1964) and partly on the work by Michelsen (1975) (see discussion on p. 8).

The oldest sediments recorded in the Gassum No. 1. - borehole are of Late Permian age (Norwood et al. 1951, unpubl., Sorgenfrei \& Buch 1964) and consist of about $5 \mathrm{~m}$ of sandstone and silty clay with anhydrite and rocksalt. The Permian sequence is overlain by about $1900 \mathrm{~m}$ of Triassic strata comprising varicoloured shales, claystones and sandstones. While most of the Triassic sediments are red and green in colour, the uppermost $200 \mathrm{~m}$ (from a depth about $1714 \mathrm{~m}$ ), referred to the Rhaetian (Sorgenfrei \& Buch 1964), are generally dark coloured. The Gassum Formation (established by Larsen (1966) and emended by Bertelsen (1978)), extends from 1648 to $1517 \mathrm{~m}$ and comprises limnic, fine- to medium grained, light grey sandstones with subordinate coal lenses and bands of marine, dark grey to black shale. Marine shales gradually become dominant towards the top of the formation and the marine, dark grey, rather uniform shale which dominates the interval from 1517 to $1203 \mathrm{~m}$, is included in

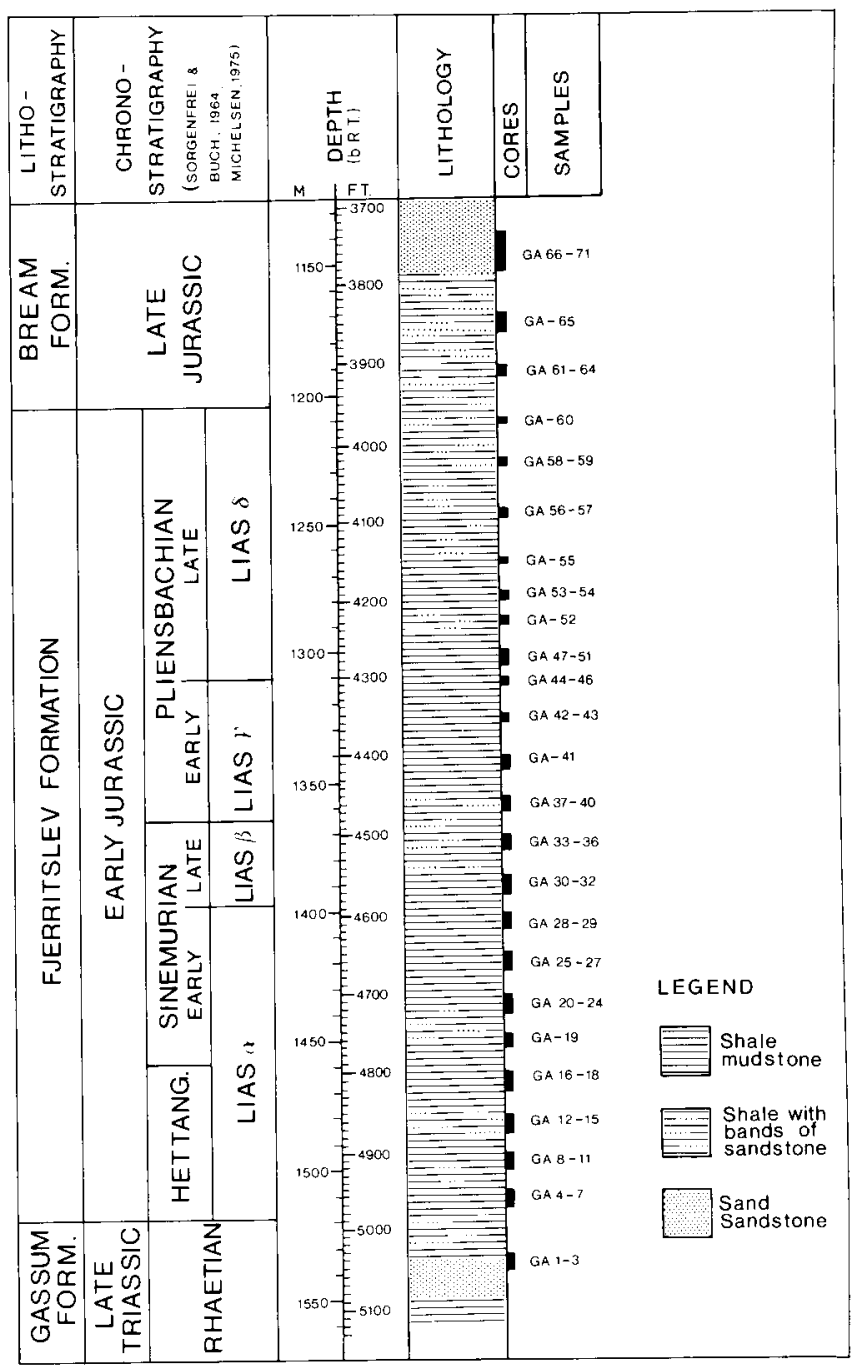

Figure 3. The Jurassic sequence of the Gassum No. 1-borehole, with the cored interval and distribution of samples. the Fjerritslev Formation (proposed by Larsen (1966), emended by Michelsen (1978)). This part of the section is erosively overlain by the Bream Formation (Deegan \& Scull (1977), emended by Michelsen (1978)), which shows a gradual upward increase in sandy material. In the basal part it is dominated by dark grey, sandy shales, with bands of light grey and greenish-grey sandstones, while from 1152 to $1078 \mathrm{~m}$ it consists predominantly of greenish-grey sand with a high mica content, intercalated with bands of greyish-green shaly siltstone. The core from 1193 to $1189 \mathrm{~m}$ has a very different appearance, comprising a hard, greenish grey claystone with shining, conchoidal fractures. Irregular patches of deep red and purple colours may indicate a weathering horizon (Norwood et al. 1951, unpubl. Larsen 1966). Above the Bream Formation are $1060 \mathrm{~m}$ of Cretaceous shales, limestones and chalk, ultimately capped by about $25 \mathrm{~m}$ of Pleistocene deposits.

\section{Bio- and chronostratigraphy}

The stratigraphical conclusions derived from the present investigation are presented in figure 9.

The chronostratigraphic subdivision presented by Sorgenfrei \& Buch (1964) (see fig. 2, 3 and 9) is based on several palaeontological, geophysical, and lithological studies. Among the most important are Frebold's (1948, unpubl.) macrofossil-analyses (particularly of the ammonite-assemblage), the "Final Report on Gassum No. 1" (Norwood et al. 1951, unpubl.) which is a summary of all recorded well-data, and analyses of foraminifera (Nørvang 1957). Nørvang's correlation of the Early Jurassic foraminiferal fauna with English and German faunas resulted in a chronostratigraphic subdivision that supported and improved Frebold's (1948, unpubl.) proposals.

The Middle and Upper Rhaetic (sensu germanico) applied to the Gassum borehole by Sorgenfrei \& Buch (1964) correspond to the Rhaetian adopted in the present work, while the Lower Rhaetic (sensu germanico) corresponds to the Late Norian (Lund 1977, Pedersen \& Lund 1980).

Some more recent biostratigraphic studies have also been carried out. Michelsen (1973) demonstrated some regional differences in the depositional environment of the lowermost Jurassic in Gassum No. 1- and four other boreholes. This was based on variations in the ostracod and holothurian faunas, combined with lithological information from Larsen (1966). Subsequently, Michelsen (1975) presented a biozonation and a chronostratigraphic subdivision of the Lower Jurassic sequence in the Gassum borehole (see fig. 9). The investigations were based on stratigraphic variations in the ostracod fauna, correlated to ostracod-zonated, ammonitedated sequences in North Germany. Finally, a palynological range-chart for the Upper Triassic and low- 
ermost Jurassic section in the Gassum No. 1-borehole has been published by Bertelsen (1978, fig. 3). The illustrated distribution of some selected miospore taxa indicate a Rhaetian age for the Vinding- and almost all the Gassum Formation, while the miospore assemblage in the topmost part of the Gassum Formation is interpreted as transitional Rhaetian-Hettangian.

\section{Position of chronostratigraphical boundaries}

According to Frebold (1948, unpubl.), the TriassicJurassic boundary is located in the interval 1534-1515 $m$ on the basis of invertebrate macrofossils, and this is supported by Bertelsen's (1978) palynological study. Norwood et al. (1951, unpubl.) placed the boundary at $1517 \mathrm{~m}$, based on a general increase in hardness of strata below this level, and this location for the boundary is followed here (in accordance with Sorgenfrei \& Buch (1964) and Michelsen (1975).

Based on ostracods the Hettangian-Early Sinemurian boundary was placed between $1463 \mathrm{~m}$ and $1454 \mathrm{~m}$ (Michelsen 1975).

The positions of the Early-Late Sinemurian, the Sinemurian-Pliensbachian, and the Early-Late Pliensbachian boundaries proposed by Michelsen (1975) diverge from those given by Sorgenfrei \& Buch (1964) (see fig. 9). The disagreement concerning the EarlyLate Sinemurian boundary is due to the lack of index- macrofossils at this level that weakens the early analysis by Frebold (1948, unpubl.) (used by Sorgenfrei \& Buch, 1964). The position of the boundary between $1402 \mathrm{~m}$ and $1393 \mathrm{~m}$ as proposed by Michelsen, is therefore the most reliable and is adopted here (fig. 3 ). The Sinemurian-Pliensbachian boundary was placed at 1366 m by Sorgenfrei \& Buch (1964) and between $1341 \mathrm{~m}$ and $1328 \mathrm{~m}$ by Michelsen (1975). Michelsen does not discuss the disagreement. The position given by Sorgenfrei \& Buch (1964) is adopted here. Finally the different evaluations of the macrofossil-rich interval covering the Early-Late Pliensbachian boundary may be due to the poor ostracod fauna at this level (Michelsen 1975). The position of the boundary at $1310 \mathrm{~m}$ given by Sorgenfrei \& Buch (1964) is therefore adopted here.

As mentioned earlier, sediments from the late Early Jurassic to the early Late Jurassic are absent in the Gassum No. 1-borehole, partly reflecting uplift of the Ringkøbing-Fyn High-area, and partly because of local salt-movements (Norwood et al. 1951, unpubl., Sorgenfrei \& Buch 1964, Larsen 1966).

The Jurassic-Cretaceous boundary is located in the unfossiliferous interval from 1144 to $1089 \mathrm{~m}$, since the underlying deposits are referred to the Late Jurassic, and the overlying sequence to the Early Cretaceous (Norwood et al. 1951, unpubl., Sorgenfrei \& Buch 1964). 


\section{Materials and methods}

\section{Sampling}

The material used in this investigation are core-samples from the Gassum No. 1-borehole made available by the Geological Survey of Denmark. In total 71 samples, numbered GA-1 to GA-71, were taken at different intervals through the latest Rhaetian and the Jurassic section. The cored intervals and the stratigraphic positions of the samples are shown in figure 3 .

\section{Palynological preparation}

About $4 \mathrm{~g}$ of crushed material from each of the 71 samples were processed using the procedure normally followed at the Section of Palynology, Geological Institute, University of Aarhus. The samples were treated in $10 \% \mathrm{HCl}$ for $20 \mathrm{~min}$. to 24 hours to dissolve the calcium carbonate; after centrifugation the $\mathrm{HCl}$ was removed. Then $40 \% \mathrm{HF}$ was added to dissolve siliceous minerals, and the samples were placed in a waterbath at $100^{\circ} \mathrm{C}$ for 2 hours. The samples were then centrifuged and the HF removed. The HF-treatment was repeated and finally the samples were again treated with $10 \% \mathrm{HCl}$ and placed in a waterbath at $100^{\circ} \mathrm{C}$ for 20-30 min. After final centrifugation and removal of the $\mathrm{HCl}$ the samples were washed with distilled $\mathrm{H}_{2} \mathrm{O}$ and sieved through a $10 \mu \mathrm{m}$ filter. The filtered residues were examined in order to decide further treatment. This treatment consisted of combinations of the following procedures: a) Heavy-liquid separation, using $\mathrm{ZnCl}$ (s.g. 1, 9), to remove insoluble mineral particles from the organic fraction.

b) Peptisator plus ultrasound-treatment on samples with flocculating organic and clayey material to disperse the residue into single grains.

c) $\mathrm{KOH}(5 \%)$ to bleach dark, carbonized palynomorphs.

d) $\mathrm{HNO}_{3}$ (conc.) to dissolve pyrite, which was frequently precipitated inside the palynomorphs, especially in the sacci of saccate pollen.

e) Extra $10 \mu \mathrm{m}$-sieving with distilled water always followed treatment with $\mathrm{KOH}$ and $\mathrm{ZnCl}_{2}$ to remove traces of chemicals remaining in the residue.

Two to four glycerine-slides for transmitted-light microscopy were prepared from each sample.

\section{Microscopical examination}

At least one slide from each sample was thoroughly examined using a Leitz Wetzlar light-microscope. Slides from 32 samples, regularly distributed throughout the studied section, were chosen for counting. The counting, carried out at a magnification of $x 400$, continued until at least 250 spores and pollen were identified from each sample (independent of the number of aquatic palynomorphs). All palynomorphs encountered were recorded whether or not they were immediately identifiable. 


\section{Palynomorph recovery}

126 different palynomorph taxa, including 55 spore species, 40 pollen species, 21 dinoflagellate-cyst species, and 10 other aquatic types, were identified. All species or types encountered are presented in the systematic section. In the range-chart the palynomorphs are listed according to their stratigraphic range in the present study and their percentage distributions in the counted samples are indicated. Each species/type in the range-chart is identified by a number which is also used in the text. "Various dinoflagellate-cysts" (number 107 in the range-chart) includes all the dinoflagellate-cyst species mentioned in figure 7 . They are not included in the systematic section but their references are shown in figure 7. Further taxonomic information can be obtained from Lentin \& Williams (1985).

Five spore-pollen zones (A to $\mathrm{E}$ ) have been proposed on the basis of the stratigraphic ranges and abundances of the palynomorphs (see p. 29). The relative abundances of the main morphological groups of palynomorphs have been calculated (fig. 10) and their stratigraphic variations correlated with previously proposed sea-level changes (Hallam 1978, 1981) (see p. 38). 
The following taxa of palynomorphs have been recorded in the studied section of the Gassum No. 1borehole. The range-chart number for each taxa is indicated together with a reference to illustrations.

The morphosystematic classification system used for the Anteturma Sporites is that proposed by Dettmann (1963) which is a revision of that proposed by Potonie \& Kremp (1954, 1955, 1956a, 1956b; Potonié 1956, 1958, 1960). For Anteturma Pollenites the corresponding morphosystematic classification system, proposed by Potonié \& Kremp (1954) is used. Taxonomic references to genera and higher taxa are not included. The descriptive terms used in this paper are defined by Tschudy (1969) and Grebe (1971).

The orientation of the grains when measuring their size is in accordance with Schulz (1967, text fig. 1). The size-measurements include sculptural-elements and is stated as follows.: a (b) $c(n=d)$, where $a$ is the minimum size, $b$ the mean-size and $c$ the maximum size measured and $d$ is the number of measurements. Accurate sizc-measurements of bisaccate pollen are difficult to obtain because of the indistinct delimitations between the corpus and the roots of the sacci and because of variable orientation of the grains. Because of this, the number of indicated size-measures for each bisaccate pollenspecies is variable. The term "sulcus" is used here to describe the distal area between the sacciroots.

Beyond the species names accepted in the present study, the synonym lists only show synonyms used in the most important references.

\section{Spores and pollen}

Anteturma Sporites H. Potonié 1893

Turma Triletes (Reinsch 1881) Dettmann 1963

Subturma Azonotriletes (Luber 1937) Dettmann 1963 Infraturma Laevigati (Bennie \& Kidston 1886) R. Potonié 1956

Genus Deltoidospora Miner 1935 emend. Danzé-Cor$\sin \&$ Laveine 1963

This genus includes laevigate, trilete spores with a triangular to subcircular amb, the trilete-mark is distinct with long sutures often bordered by folds and/or a proximal-kyrtome (a thickening of the exine in the contact-area, parallel to the trilete-mark).

\section{Deltoidospora toralis (Leschik) Lund}

Pl. 1, figs. $1 \& 2$

Range-chart number: 27

1955: Laevigatisporites toralis - Leschik, p. 12; pl. 1, figs. 1, 2.

1958: Concavisporites toralis (Leschik 1955) - Nilsson, p. 34; pl. 1, figs. 12,13

1977: Deltoidospora auritora (Reinhardt 1961) - Lund, p. 50; pl. 1, fig. 5 .

1977: Deltoidospora toralis (Leschik 1955) - Lund, p. 49; pl. 1, figs. 2,3 .

Equatorial diameter: 26 (37) $46 \mu \mathrm{m}(\mathrm{n}=20)$.

This species is characterized by having a proximalkyrtome of variable form, and a thin, laevigate exine, often infolded between equator and the kyrtome. According to Lund (1977) $D$. auritora differs from $D$. toralis in having a proximal-kyrtome which continues around the angles. In the present study a great variation of Deltoidospora-types and contact-area thickenings was recorded, including forms intermediate between $D$. auritora and $D$. toralis. $D$. auritora is therefore treated as a synonym of $D$. toralis.

\section{Deltoidospora minor (Couper) Pocock}

Pl. 1, fig. 4

Range-chart number: 60

1953: Cyathidites minor - Couper, p. 28; pl. 2, fig. 13

1970: Deltoidospora minor (Couper 1953) - Pocock, p. 28; pl. 5, fig.3.

Equatorial diameter: $26(32) 40 \mu \mathrm{m}(\mathrm{n}=10)$

$D$. minor differs from $D$. toralis in the absence of a proximal-kyrtome.

Deltoidospora crassexina (Nilsson) Lund

Pl. 1, fig. 3

Range-chart number: 15

1958: Concavisporites crassexinus - Nilsson, p. 35; pl. 1, fig. 11.

1977: Deltoidospora crassexina (Nilsson 1958) - Lund, p. 51; pl. 1, fig. 4 ; pl. 12 , fig. 8 .

Equatorial diameter: 31 (34) $40 \mu \mathrm{m}(\mathrm{n}=10)$.

This species is characterized by having a proximalkyrtome and in addition three semidistal, interradial exine-thickenings.

Genus Cibotiumspora Chang 1965 
Cibotiumspora jurienensis (Balme) Filatoff

Pl. 1, fig. 6

Range-chart number: 19

1957: Concavisporites jurienensis - Balme, p. 20; p1. 2, figs. 30, 31

1975: Cibotiumspora jurienensis (Balme 1957) - Filatoff, p. 61; pl. 10 , figs. 8-13.

Equatorial diameter: 25 (30) $36 \mu \mathrm{m}(\mathrm{n}=8)$..

A proximal-kyrtome is present in many specimens. The exine is laevigate and $1-2 \mu \mathrm{m}$ thick. On the distal surface there is a fold across the angular part of the spore-outline perpendicular to the rays of the triletemark. The folds occur on at least one, but generally on all three of the angles.

C. jurienensis may be poorly developed spores of the Deltoidospora-type. The only differences is the distal (secondary?) folds and the smaller size.

\section{Genus Intrapunctisporis Krutzsch 1959}

This genus differs from Deltoidospora in having a scabrate sculpture on the inside of the exine.

Intrapunctisporis toralis (Leschik) Lund

Pl. 1, fig. 5

Range-chart number: 23

1955: Punctatisporites toralis - Leschik, p. 19; pl. 2, fig. 11

1977: Intrapunctisporis toralis (Leschik 1955) - Lund, p. 51; pl. 1, fig. 8 .

Equatorial diameter: 40 (44) $50 \mu \mathrm{m}(\mathrm{n}=10)$.

The proximal-kyrtome is often weakly developed.

Genus Punctatisporites Ibrahim 1933 emend. Potonié \& Kremp 1954

The proposal of Kedves \& Simoncsics (1964) to use Punctatisporites also on Mesozoic material is followed here.

\section{Punctatisporites globosus (Leschik) Lund}

Pl. 1, fig. 7

Range-chart number: 13

1955: Laevigatisporites globosus - Leschik, p. 11; pl. 1, fig. 5

1958: Todisporites minor - Couper, p. 135; pl. 16, figs. 9, 10

1977: Punctatisporites globosus (Leschik 1955) - Lund, p. 52; pl. 1, fig. 11 .

Equatorial diameter: $40(45) 50 \mu \mathrm{m}(\mathrm{n}=12)$.

The exine is thin (about $1 \mu \mathrm{m}$ ), laevigate or scabrate, often secondarily folded.

$P$. globosus and P. major are separated only by a bimodal size frequency curve, with a spore-diameter of $52 \mu \mathrm{m}$ as the size limit (see Couper (1958, p. 134-135; text fig. 8)).
Punctatisporites major (Couper) Kedves \& Simoncsics Pl. 1, fig. 8

Range-chart number: 33

1958: Todisporites major - Couper, p. 134; pl. 16, figs. 6-8

1964: Punctatisporites major (Couper 1958) - Kedves \& Simoncsics, p. 13 ; pl. 3 , figs. 1,2 .

Equatorial diameter: $55(58) 75 \mu \mathrm{m}(\mathrm{n}=10)$.

\section{Genus Retusotriletes Naumova 1953}

This genus differs from Punctatisporites in having a perfect curvature.

Retusotriletes mesozoicus Klaus

Pl. 1, fig. 9

Range-chart number: 4

1960: Retusotriletes mesozoicus - Klaus, p. 120; pl. 28, fig. 6.

Equatorial diameter: $33(42) 50 \mu \mathrm{m}(\mathrm{n}=8)$.

Genus Calamospora Schopf, Wilson \& Bentall 1944

This genus differs from Punctatisporites and Retusotriletes in having a very small trilete-mark and a very thin exine.

Calamospora tener Leschik emend. Mädler

Pl. 1, fig. 10

Range-chart number: 29

1955: Laevigatisporites tener - Leschik, p. 13; pl. 1, fig. 20

1964b: Calamospora tener Leschik 1955 emend. Mädler, p. 92; pl. 8, fig. 2 .

Equatorial diameter: $26(35) 50 \mu \mathrm{m}(\mathrm{n}=10)$.

The trilete mark is often indistinct because of secondary folding. The exine is laevigate and only about 0.5 $\mu \mathrm{m}$ thick.

Calamospora $\mathrm{sp}$.

Pl. 1, fig. 11

Range-chart number: 24

Equatorial diameter: $26(37) 46 \mu \mathrm{m}(\mathrm{n}=4)$.

Identical with $C$. tener apart from a thicker exine (about $1 \mu \mathrm{m}$ ), resulting in less tendency to folding.

Genus Stereisporites Pflug 1953

Stereisporites is used here as proposed by Krutzsch (1963) to encompass small, "spagnoide" microspores, unsculptured or with a sculptured distal exine and/or polar thickenings. Cingulate microspores comparable to Stereisporites are included in Infraturma Cingulati. 
Stereisporites stereoides (Potonié \& Venitz) Pflug

Pl. 1, fig. 12

Range-chart number: 16

1934: Laevigatisporites stereoides - Potonié \& Venitz, p. 11; pl. 1, figs. 4,5

1953: Stereisporites stereoides (Potonié \& Venitz 1934) - Pflug, in Thomson \& Pflug (1953), p. 53; pl. 1, figs. 64-73.

Equatorial diameter: 17 (22) $24 \mu \mathrm{m}(\mathrm{n}=10)$.

The exine is $1.5-2.0 \mu \mathrm{m}$ thick and laevigate.

Stereisporites antiquasporites (Wilson \& Webster) Dettmann

Pl. 1, fig. 13

Range-chart number: 44

1946: Sphagnum antiquasporites - Wilson \& Webster, p. 273; fig. 2 1963: Stereisporites antiquasporites (Wilson \& Webster 1946) - Dettmann, p. 25; pl. 1, figs. $20,21$.

Equatorial diameter: $20(23) 26 \mu \mathrm{m}(\mathrm{n}=6)$.

The exine is laevigate, about $2 \mu \mathrm{m}$ thick and with a circular thickening at the distal pole, $6-8 \mu \mathrm{m}$ in diameter. In addition there are some weakly developed radial thickenings in the equatorial region.

\section{Stereisporites punctus (Klaus) Krutzsch}

Pl. 2, fig. 1

Range-chart number: 47

1960: Distalanulisporites punctus - Klaus, p. 133; pl. 28 , fig. 8

1963: Stereisporites (Distalanulisporites) punctus (Klaus 1960) Krutzsch, p. 19.

Equatorial diameter: 23 (25) $28 \mu \mathrm{m}(\mathrm{n}=11)$.

The exine is $1.0-1.5 \mu \mathrm{m}$ thick, unsculptured, but with a distinct ring-formed thickening of the exine around the distal pole, often in combination with some indistinct, radiating grooves.

Stereisporites cicatricosus (Rogalska) Schulz

P1. 2, fig. 2

Range-chart number: 42

1954: Sporites cicatricosus - Rogalska, p. 44; pl. 12, fig. 11.

1967: Stereisporites (Rogalskaisporites) cicatricosus (Rogalska 1954) - Schulz, p. 557; pl. 1, figs. 8, 9

Equatorial diameter: 20 (26) $34 \mu \mathrm{m}(\mathrm{n}=12)$.

The exine is $1.0-1.5 \mu \mathrm{m}$ thick, proximally unsculptured, distally with distinct radiating grooves near the equator. A weak ring-thickening and/or a circular area with thickened exine is often present at the distal pole.

Stereisporites cf. seebergensis Schulz

Pl. 2, fig. 4

Range-chart number: 80

Description: Trilete spore with subtriangular amb, convex sides and rounded angles. The trilete-mark is in- distinct and the sutures extend for $1 / 2$ to $2 / 3$ of the sporeradius. A distinct perfect curvature is present. The exine is $1.0-1.5 \mu \mathrm{m}$ thick, laevigate at the proximal surface and with a delicate foveo-reticulate sculpturing at the distal surface.

Equatorial diameter: 23 (29) $33 \mu \mathrm{m}(\mathrm{n}=3)$.

Remarks: This species differs from $S$. cf. hauterivensis in having a thinner exine and a more delicate sculpture. It differs from the spores of $S$. seebergensis, originally described by Schulz (in Döring et al. (1966)), in having a more distinct sculpture (slightly higher sculptured elements)).

\section{Stereisporites cf. hauterivensis Döring}

Pl. 2, fig. 3

Range-chart number: 18

Description: Trilete spore with subtriangular amb, convex sides, rounded angles and a slightly undulating edge. The trilete-mark has a narrow but distinct labrum, the sutures extend for $1 / 2$ to $2 / 3$ of the sporeradius. The exine is about $2 \mu \mathrm{m}$ thick, laevigate at the proximal surface, foveo-reticulate at the distal surface. Equatorial diameter: 23 (25) $26 \mu \mathrm{m}(\mathrm{n}=5)$.

Remarks: These specimens differ from the spores of $S$. hauterivensis, originally described by Döring (1966) (in Döring, Krutzsch, Schulz \& Timmermann (1966)), in having a very narrow labrum.

Infraturma Apiculati (Bennie \& Kidston 1886) R. Potonié 1956

\section{Genus Trachysporites Nilsson 1958}

This genus includes trilete, triangular to subcircular spores with an irregular, mixed sculpturing. Trachysporites differs from Conbaculatisporites in having lower sculptural elements and from Baculatisporites in having a more triangular amb.

Trachysporites fuscus Nilsson

Pl. 2, fig. 5

Range-chart number: 14

1958: Trachysporites fuscus - Nilsson, p. 38; pl. 2, fig. 1

Equatorial diameter: $30(40) 46 \mu \mathrm{m}(\mathrm{n}=12)$.

The exine is $1.5-2.0 \mu \mathrm{m}$ thick, sculptured with densely arranged granulae, about $1 \mu \mathrm{m}$ high, slightly elongated and irregularly orientated, partly fused to an irregular reticulum.

Trachysporites asper Nilsson

Pl. 2, fig. 6

Range-chart number: 21

1958: Trachysporites asper - Nilsson, p. 39; pl. 2, fig. 3 
Equatorial diameter: $32(40) 43 \mu \mathrm{m}(\mathrm{n}=10)$.

The exine is about $1 \mu \mathrm{m}$ thick, sculptured with dispersed micro-coni $(<1 \mu \mathrm{m})$, connected at basis, forming an irregular micro-reticulum.

Trachysporites cf. sparsus (Bharadwaj \& Singh) Lund Pl. 2, fig. 7

Range-chart number: 12

Description: Trilete spore with triangular to subtriangular amb and rounded angles. The trilete-mark has a faintly developed labrum, the sutures are straight and extend for $4 / 5$ of the spore-radius. The exine is $1.5-2.0$ $\mu \mathrm{m}$ thick, sculptured with irregularly dispersed granulae, partly connected, forming an irregular reticulum. Equatorial diameter: 33 (43) $52 \mu \mathrm{m}(\mathrm{n}=12)$.

Remarks: The specimens recorded in the present study differs from Lunzisporites sparsus Bharadwaj \& Singh (1964), in having an exine sculptured with granulae and verrucae, otherwise the exine is laevigate. Nevertheless, the specimens compare very well with the illustration of Lunzisporites sparsus Bharadwaj \& Singh (1964) and also with the specimens of Trachysporites cf. sparsus recorded by Lund (1977). Lund erects the new combination Trachysporites sparsus.

\section{Genus Conbaculatisporites Klaus 1960}

According to the generic diagnosis Conbaculatisporites includes subtriangular spores with a sculpture consisting exclusively of baculae. However, many authors also include species with a mixed sculpture, consisting of baculae, spinae, and coni, in this genera (Lund 1977, Schuurman 1977, Pedersen \& Lund 1980, Hoelstad 1985). This approach is followed here.

\section{Conbaculatisporites mesozoicus Klaus}

Pl. 2, fig. 8

Range-chart number: 11

1960: Conbaculatisporites mesozoicus - Klaus, p. 126; pl. 29, fig. 15

Equatorial diameter: $36(44) 60 \mu \mathrm{m}(\mathrm{n}=10)$.

The exine is thin (about $1 \mu \mathrm{m}$ ) and sculptured with coni, spinae, and baculae. The sculptural-elements are up to $3 \mu \mathrm{m}$ high, connected at basis, forming a low, indistinct reticulum. The sculpturing is highest and most dense at the angles. C. mesozoicus differs from $C$. spinosus in having a relatively shorter polar-axis and a larger size.

\section{Conbaculatisporites spinosus (Mädler) Lund}

Pl. 2, fig. 9

Range-chart number: 28

1964a: Anemiidites spinosus - Mädler, p. 180; pl. 2, fig. 11

1977 : Conbaculatisporites spinosus (Mädler 1964a) - Lund, p. 56; pl. 2, figs. 11a, b
Equatorial diameter: 23 (30) $36 \mu \mathrm{m}(\mathrm{n}=12)$.

Genus Baculatisporites Thomson \& Pflug 1953 emend. Krutzsch 1967

This genus includes trilete spores with a circular to subcircular amb. The exine-ornamentation consists of more or less pointed baculae or granulae. The sculptural-elements are more or less densely spaced, and also the size of the elements are variable.

\section{Baculatisporites wellmanii (Couper) Krutzsch \\ Pl. 2, fig. 11 \\ Range-chart number: 25}

1953: Osmundacidites wellmanii-Couper, p. 20; pl. 1, fig. 5

1959: Baculatisporites wellmanii (Couper 1953) - Krutzsch, p. 142

Equatorial diameter: 33 (43) $50 \mu \mathrm{m}(\mathrm{n}=11)$.

The exine is about $1 \mu \mathrm{m}$ thick, ornamented with densely spaced baculae, about $1 \mu \mathrm{m}$ high. The sculpturing is reduced around the trilete-mark. $B$. wellmanii differs from $B$. comaumensis in having lower, more fused, and more densely spaced sculptural elements.

\section{Baculatisporites comaumensis (Cookson) Potonié}

Pl. 2, fig. 12

Range-chart number: 26

1953: Triletes comaumensis - Cookson, p. 470; pl. 2, figs. 27, 28

1956: Baculatisporites (Triletes) comaumensis (Cookson 1953) - Potonié, p. 33

Equatorial diameter: 35 (44) $55 \mu \mathrm{m}(\mathrm{n}=10)$.

The exine is about $1 \mu \mathrm{m}$ thick, sculptured with regularly spaced baculae, 1.5-2.0 $\mu \mathrm{m}$ high.

Baculatisporites oppressus (Leschik) Lund

Pl. 2, fig. 10

Range-chart number: 5

1955: Cyclogranisporites oppressus - Leschik, p. 17; pl. 1, fig. 23

1977: Baculatisporites oppressus (Leschik 1955) - Lund, p. 57; pl. 2, fig. $15 \mathrm{a}, \mathrm{b}$

Equatorial diameter: 30 (34) $38 \mu \mathrm{m}(\mathrm{n}=11)$.

This species differs from the other Baculatisporitesspecies in having a mixed sculpturing, consisting of microbaculae, -granulae, and -coni, a smaller size, a more triangular amb, and in having exine-folds bordering the trilete-mark. The specimens recorded in the present study shows a remarkably large size compared to the size of $20 \mu \mathrm{m}$ stated by Leschik (1955).

\section{Genus Apiculatisporis Potonié \& Kremp 1956}

Apiculatisporis ovalis (Nilsson) Norris

Pl. 3, fig. 1

Range-chart number: 22 
1958: Acanthotriletes ovalis - Nilsson, p. 40; pl. 2, figs. 8,9

1965: Apiculatisporis ovalis (Nilsson 1958) - Norris, p. 245; figs.2b, $18,22,23$

Equatorial diameter: $30(37) 50 \mu \mathrm{m}(\mathrm{n}=10)$.

Spore with sub-circular to oval amb. The exine is 0.5-1.0 $\mu \mathrm{m}$ thick, sculptured with irregularly spaced coni and spinae, a few baculae can be present. The sculptural elements are $0.5-1.5 \mu \mathrm{m}$ high. A. ovalis could be confused with Baculatisporites comaumensis but differs by the dominance of coni and spinae instead of baculae.

\section{Genus Anapiculatisporites Potonié \& Kremp 1954}

Anapiculatisporites telephorus (Pautsch) Klaus

Pl. 3, fig. 3

Range-chart number: 8

1958: Sporites telephorus - Pautsch, p. 323; pl. 1, fig. 12

1960: Anapiculatisporites telephorus (Pautsch 1958) - Klaus, p. 124; pl. 29 , fig. 17

Equatorial diameter: $33(40) 50 \mu \mathrm{m}(\mathrm{n}=8)$.

The exine is about $1 \mu \mathrm{m}$ thick, laevigate to punctate in the contact-area, distally and equatorially sculptured with regularly spaced spinae and coni 1-2 $\mu \mathrm{m}$ high. There are 25-35 spinae/coni around the equator. $A$. telephorus differs from $A$. spiniger in having lower sculptural-elements with a broader base.

Anapiculatisporites spiniger (Leschik) Reinhardt pl. 3, fig. 2

Range-chart number: 2

1955: Apiculatisporites spiniger - Leschik, p. 18; pl. 2, figs.6, 7 1961: Anapiculatisporites spiniger (Leschik 1955) - Reinhardt, p. 707; pl. 1, fig. 8

Equatorial diameter: 30 (35) $40 \mu \mathrm{m}(\mathrm{n}=4)$.

Spore with subtriangular to circular amb. The exine is $1.0-1.5 \mu \mathrm{m}$ thick, punctate in the contact area but equatorially and distally the exine is sculptured with spinae, $2-3 \mu \mathrm{m}$ high. There are $40-45$ spinae around the equator.

Genus Acanthotriletes Naumova 1937 emend. Potonié \& Kremp 1954

\section{Acanthotriletes varius Nilsson}

Pl. 3, fig. 4

Range-chart number: 1

1958: Acanthotriletes varius - Nilsson, p. 42 ; pl. 2, fig. 10

Equatorial diameter: $30(35) 40 \mu \mathrm{m}(n=6)$.

This species is characterized by a triangular amb with concave sides and an exine, about $2 \mu \mathrm{m}$ thick, sculp- tured with spinae of variable height, up to $2 \mu \mathrm{m}$. There are about 30 spinae around the equator.

\section{Genus Manumia Pocock 1970}

Manumia variverrucata Couper emend. Hoelstad

Pl. 3, fig. 10

Range-chart number: 85

1958: Concavisporites variverrucatus - Couper, p. 142; pl. 22, figs. 4,5

1985: Manumia variverrucata (Couper 1958) - Hoelstad, p. 123; pl. 2, figs. $15-17$

The exine is $1.5 \mu \mathrm{m}$ thick, distally and proximally sculptured with dispersed, irregularly spaced verrucae. The equatorial diameter of the illustrated specimen is 30 $\mu \mathrm{m}$. This specimen was the only one recorded.

Genus Uvaesporites Döring 1965

Uvaesporites argenteaeformis (Bolchovitina) Schulz

Pl. 3, figs. 5, 6

Range-chart number: 39

Iraquispora laevigata (Mädler) Lund

Pl. 3, fig. 7

Range-chart number: 35

1964a: Kyrtomisporites laevigatus - Mädler, p. 188; pl. 3, fig. 4 1977 : Iraquispora laevigata (Mädler 1964a) - Lund, p. 59; pl. 3, fig. 12

This species is characterized by a large, distinct triletemark, bordered by a conspicuous proximal-kyrtome which radially reaches out beyond the rest of the spore. The exine is 3-5 $\mu \mathrm{m}$ thick and sculptured with large, irregularly spaced verrucae, not higher than $1 \mu \mathrm{m}$, resulting in an undulating edge. The equatorial diameter of the illustrated specimen is $56 \mu \mathrm{m}$. This specimen was the only one recorded.

\section{Genus Uvaesporites Döring 1965}

Uvaesporites argenteaeformis (Bolchovitina) Schulz

Pl. 3, figs. 5, 6

Range-chart number: 39

1953: Stenozonotriletes argenteaeformis - Bolchovitina, p. 51; pl. 7, fig. 9

1961: Triletes reissingeri - Reinhardt, p. 707; pl. 2, figs.1, 2

1967: Uvaesporites argenteaeformis (Bolchovitina 1953) - Schulz, p. $560 ;$ pl. 2 , figs. 10,$11 ;$ pl. 23 , fig. 2

1977: Uvaesporites reissingeri (Reinhardt 1961) - Lund, p. 60; pl. 3, fig. 14

Equatorial diameter: $38(44) 50 \mu \mathrm{m}(\mathrm{n}=3)$.

$U$. argentaeaformis is readily recognized by a dense sculpturing of large verrucae (diameter $2-10 \mu \mathrm{m}, 2-8$ $\mu \mathrm{m}$ high) on the equatorial and distal face. In the contact-area the exine is laevigate. 
Infraturma Murornati Potonié \& Kremp 1954

Genus Lycopodiumsporites Thiergart 1938 ex. Delcourt \& Sprumont 1955

Remarks: This genus includes trilete spores with subtriangular to subcircular amb, a reticulate sculpture on the distal and equatorial surface and often also in the contact-area. The genus Lycopodiumsporites is of questionable validity (Döring, Krutzsch, Mai \& Schulz, 1963, Dettmann 1963, Tralau 1968), but is widely used. The genus Retitriletes (Hammen 1956 ex. Pierce 1961) emend. Döring et al. (1963) is here regarded as a junior synonym of Lycopodiumsporites.

Lycopodiumsporites semimuris Danzé-Corsin \& Laveine

Pl. 3, figs.8 \& 9

Range-chart number: 73

1963: Lycopodiumsporites semimuris - Danzé-Corsin \& Laveine, p. 79 ; pl. 6, figs. $15 \mathrm{a}, \mathrm{b}, 16 \mathrm{a}, \mathrm{b}, 17 \mathrm{a}, \mathrm{b}, \mathrm{c}$

Equatorial diameter: 28 (33) $40 \mu \mathrm{m}(\mathrm{n}=10)$.

L. semimuris differs from the other species referred to Lycopodiumsporites in having a reduced reticulum.

Lycopodiumsporites austroclavatidites (Cookson) Potonié

Pl. 3, fig. 11

Range-chart number: 71

1953: Lycopodium austroclavatidites - Cookson, p. 269; pl. 2, fig. 35 1956: Lycopodiumsporites (al. Lycopodium) austroclavatidites (Cookson 1953) - Potonié, p. 46

1963: Retitriletes austroclavatidites (Cookson 1953) - Döring, Krutzsch, Mai \& Schulz, in Krutzsch (1963, lief. II), p. 16

Equatorial diameter: $26(35) 46 \mu \mathrm{m}(\mathrm{n}=10)$.

The exine is about $1 \mu \mathrm{m}$ thick, distally and equatorially sculptured with a conspicuous reticulum, 3-5 $\mu \mathrm{m}$ high. The diameter of the luminae is 4-6 $\mu \mathrm{m}, 5-7$ luminae per spore-diameter. In the contact-area the exine is sculptured with an indistinct reticulum with a lumen-diameter of 6-10 $\mu \mathrm{m}$. $L$. austroclavatidites differs from $L$. clavatoides in having more luminae with a smaller diameter.

Lycopodiumsporites clavatoides (Couper) pro parte emend. Tralau

Pl. 3, fig. 12

Range-chart number: 79

1958: Lycopodiumsporites clavatoides - Couper, p. 132; pl. 15, figs.10-13

1963: Retitriletes clavatoides (Couper 1958) - Döring, Krutzsch, Mai \& Schulz, in Krutzsch (1963, lief. II), p. 16

1968: Lycopodiumsporites clavatoides (Couper 1958) pro parte emend. - Tralau, p. 49 ; pl. 1 , figs. $3-5$

Equatorial diameter: 34 (38) $42 \mu \mathrm{m}(\mathrm{n}=5)$.
The exine is about $1 \mu \mathrm{m}$ thick, laevigate in the contactarea but equatorially and distally the exine is sculptured with a conspicuous reticulum, 3-4 $\mu \mathrm{m}$ high. The diameter of the luminae is 6-14 $\mu \mathrm{m}$ and there are 3-5 luminae per spore-diameter.

\section{Genus Contignisporites Dettmann 1963}

\section{Contignisporites problematicus (Couper) Döring}

Pl. 4, figs.1-3

Range-chart number: 3

1958: Cingulatisporites problematicus - Couper, p. 146; pl. 24, figs.11-13

1965: Contignisporites problematicus (Couper 1958) - Döring, p. 51; pl. 18 , figs. $6-8$

Equatorial diameter: $33(46) 60 \mu \mathrm{m}(\mathrm{n}=12)$.

Proximally the spore is unsculptured. At the equator there is a "cingulum-like" thickening of the exine, consisting of fused verrucae and distally the exine is sculptured with randomly orientated rugulae and/or elongated verrucae, 3-7 $\mu \mathrm{m}$ wide.

\section{Genus Lycopodiacidites Couper 1953}

\section{Lycopodiacidites rugulatus (Couper) Schulz}

Pl. 4, fig. 12

Range-chart number: 43

1958: Perotriletes rugulatus - Couper, p. 147; pl. 25, figs.7, 8

1967: Lycopodiacidites rugulatus (Couper 1958) - Schulz, p. $573 ; \mathrm{pl}$. 7 , figs. 15,16

Equatorial diameter: $63(70) 76 \mu \mathrm{m}(\mathrm{n}=3)$.

The exine is about $2 \mu \mathrm{m}$ thick, sculptured with partly fused rugulae, $3-5 \mu \mathrm{m}$ wide, $1-2 \mu \mathrm{m}$ high, forming an incomplete zigzag- pattern. The sculpturing is less distinct on the proximal side of the spore.

\section{Cf. Lycopodiacidites}

Pl. 4, fig. 10

Range-chart number: 61

Description: Trilete spore with subtriangular amb, convex sides, and rounded angles. The trilete-mark is simple; the sutures extend for $3 / 4$ of the spore-radius. The exine is laevigate in the contact-area, but distally and equatorially it is sculptured with distinct rugulae, 2-3 $\mu \mathrm{m}$ wide, 1-2 $\mu \mathrm{m}$ high, forming an incomplete zigzagpattern. The equatorial diameter of the illustrated specimen is $32 \mu \mathrm{m}$.

Remarks: Only two specimens of this type were recorded. Based on form and sculpturing the spores are referred to the genus Lycopodiacidites, but they are unusually small compared to the species normally referred to this genus.

Genus Staplinisporites Pocock 1962 
Staplinisporites telatus (Balme) Döring

Pl. 4, figs. 4 \& 5

Range-chart number: 89

1957: Microreticulatisporites telatus - Balme, p. 25; pl. 4, figs. 52, 53

1965: Staplinisporites telatus (Balme 1957) - Döring, p. 45; pl. 15, figs. $6-8$

Equatorial diameter: $40(43) 46 \mu \mathrm{m}(\mathbf{n}=5)$.

On the proximal surface the exine is laevigate. On the distal surface the sculpture includes a polar, punctate, circular thickening, a semidistal, concentric, sinuous ridge and, in addition, some weak, radially disposed elevations.

\section{Genus Cicatricosisporites Potonié \& Gelletich 1933}

\section{Cicatricosisporites sp.}

Pl. 4, fig. 6

Range-chart number: 74

Description: Trilete spore with subtriangular amb, straight or slightly convex sides, and pointed to rounded angles. The trilete-mark is indistinct, the sutures are straight and extend to the equator. The exine is thin, laevigate in the contact-area, but distally and equatorially sculptured with three sets of parallel muri, each set starting at the proximal side, close to one of the angles, spreading out on the distal side running parallel to the interradial edge, converging and ending up at the next angle. The individual muri are slightly sinuous and about $2 \mu \mathrm{m}$ wide. The equatorial diameter of the illustrated specimen is $50 \mu \mathrm{m}$.

Remarks: Only two specimens were recorded.

\section{Infraturma Auriculati (Schopf 1938) Dettmann 1963}

\section{Genus Triancoraesporites Schulz 1962}

Triancoraesporites ancorae (Reinhardt) Schulz

Pl. 4, fig. 11

Range-chart number: 10

1962: Waltzispora ancorae - Reinhardt, p. 705; pl. 1, fig. 14

1967: Triancoraesporites ancorae (Reinhardt 1962) - Schulz, p. 580; pl. 11 , figs. 4,5

Equatorial diameter: 31 (32) $33 \mu \mathrm{m}(\mathrm{n}=4)$.

This species is characterized by a triangular amb with distinctly concave sides and truncate to rounded, "anchor-shaped", angles. The exine is laevigate, about 1 $\mu \mathrm{m}$ thick and often slightly thickened in the contactarea and at the angles.

Genus Trilobosporites Pant 1954 ex. Potonié 1956

Trilobosporites sp.

Pl. 5, fig. 3

Range-chart number: 93
Description: Trilete spore with triangular amb, straight to slightly concave sides, and rounded angles. The trilete-mark is distinct with labrum, the sutures extend for $3 / 4$ of the spore-radius. The exine is, proximally as well as distally, sculptured with low, weakly-developed verrucae, up to $5 \mu \mathrm{m}$ in diameter. The exine is characteristically thickened at the angles, $7-10 \mu \mathrm{m}$ thick, while the interradial exine is $3-5 \mu \mathrm{m}$. The equatorial diameter of the illustrated specimen is $62 \mu \mathrm{m}$.

Remarks: This specimen was the only one recorded.

Genus Platyptera Naumova 1934 ex. Naumova 1938

Platyptera trilingua (Horst) Schulz

Pl. 4, fig. 9

Range-chart number: 81

1943: Triletes (Zonale) trilinguis - Horst, figs. 55, 56

1967: Platyptera trilingua (Horst 1943) - Schulz, p. 579; pl. 11, figs. 1,2

This species is characterized by having a distinct, radial exine-thickening in a 4-7 $\mu \mathrm{m}$ wide zone, lobed at the edge. The rest of the exine is laevigate, $2 \mu \mathrm{m}$ thick. The equatorial diameter of the illustrated specimen is 37 $\mu \mathrm{m}$. This specimen was the only one recorded.

Infraturma Tricrassati Dettmann 1963

Genus Gleicheniidites Ross 1949

Gleicheniidites senonicus Ross

Pl. 5, fig. 4

Range-chart number: 90

1949: Gleicheniidites senonicus - Ross, p. 31; pl. 1, fig 3, 4

Equatorial diameter: 23 (29) $38 \mu \mathrm{m}(\mathrm{n}=10)$.

The exine is laevigate, about $1 \mu \mathrm{m}$ thick in the radial regions and $2-4 \mu \mathrm{m}$ thick in the interradial parts.

Gleicheniidites conspiciendus (Bolkhovitina) Krutzsch PI. 5, fig. 5

Range-chart number: 88

1953: Gleichenia conspicienda-Bolkhovitina, p. 45; pl. 8, figs. 4, 5 1959: Gleicheniidites (Peregrinisporis) conspiciendus (Bolkhovitina 1953) - Krutzsch, p. 114

Equatorial diameter: 26 (29) $30 \mu \mathrm{m}(\mathrm{n}=3)$.

This species differs from $G$. senonicus in having a scabrate to finely intrapunctate sculpture. The exine is about $1 \mu \mathrm{m}$ thick in the radial regions, interradially thickened to $2-4 \mu \mathrm{m}$.

Genus Zebrasporites Klaus 1960 emend. Schulz 1967

Zebrasporites interscriptus (Thiergart) Klaus

Pl. 4 , figs. $7 \& 8$

Range-chart number: 67 
1949: Sporites interscriptus - Thiergart, pl. 2, fig. 9

1960: Zebrasporites (al. Sporites) interscriptus (Thiergart 1949) Klaus, p. 139

This species is readily recognized by the three-lobed zona and the striated appearance. The equatorial diameter of the illustrated specimen is $30 \mu \mathrm{m}$. This specimen was the only one recorded.

\section{Infraturma Cingulati Potonié \& Klaus 1954}

Genus Lycospora Schopf, Wilson \& Bentall 1944 emend. Potonié \& Kremp 1954

\author{
Lycospora salebrosacea (Maljavkina) Schulz \\ Pl. 5, fig. 8 \\ Range-chart number: 84
}

1949: Volucellina salebrosacea - Maljavkina, p. 65; pl. 13, fig. 14 1967: Lycospora salebrosacea (Maljavkina 1949) - Schulz, p. 584; pl. 13 , figs. $8-10$

Equatorial diameter: 30 (32) $33 \mu \mathrm{m}(\mathbf{n}=3)$.

The cingulum is $3-5 \mu \mathrm{m}$ wide. The exine is laevigate on the proximal surface and punctate to scabrate on the distal surface.

Genus Densosporites Berry 1937 emend. Potonié \& Kremp 1954

Densosporites fissus (Reinhardt) Schulz

Pl. 5, fig. 1

Range-chart number: 45

1964: Densoisporites fissus - Reinhardt, p. 54; pl. 2, figs.1-3

1967: Densosporites fissus (Reinhardt 1964) - Schulz, p. 582; pl. 12 , figs. 5,6

Equatorial diameter: $36(41) 46 \mu \mathrm{m}(\mathrm{n}=7)$.

The cingulum is $8-12 \mu \mathrm{m}$ wide and the outer edge is often slightly sinuous. The exine is laevigate to finely intrareticulate.

\section{Genus Densoisporites Weyland \& Krieger 1953}

\section{Densoisporites microrugulatus Brenner \\ Pl. 5, fig. 6}

1963: Densoisporites microrugulatus - Brenner, p. 61; pl. 15, fig. 6; pl. 16, fig. 1

The cingulum is $8-12 \mu \mathrm{m}$ wide, overlapping the inner body in a $3 \mu \mathrm{m}$ wide zone. The outer edge of the cingulum is irregularly sinuous. The exine of the body is thin, with an irregular sculpture of densely spaced microrugulae. The exine of the cingulum shows a reticulate sculpturing, often continued on the proximal, radial part of the body, outside the contact-area. The equatorial diameter of the illustrated specimen is 71 $\mu \mathrm{m}$.
As the only recorded specimen of this type was found in one of the samples not counted (GA-66), it is not mentioned in the range-chart.

\section{Genus Cingutriletes Pierce 1961}

\section{Cingutriletes infrapunctus (Schulz) Morbey}

Pl. 5, fig. 2

Range-chart number: 38

1970: Stereisporites (Cingutriletes) infrapunctus - Schulz, p. 688; pl 130, figs.22, 23; pl. 131, fig. 1

1975: Cingutriletes infrapunctus (Schulz 1970) - Morbey pl. 9, fig. 4

Equatorial diameter: $24(25) 26 \mu \mathrm{m}(\mathrm{n}=2)$.

The width of the cingulum is about $1 / 3$ of the sporeradius. The exine is intrapunctate overall, and in addition there is an indistinct, proximal polar-thickening. This species is, in accordance with Morbey (1975), referred to the genus Cingutriletes in preference to Stereisporites, with the intention of following the morphosystematic system. Morbey (1975) does not mention his proposal in the text, but uses the new combination in the "Explanation of Plates" (p. 72; pl. 9, fig. 4). See also remarks to the genus Stereisporites.

Genus Cingulizonates Dybova \& Jachowicz 1957

\author{
Cingulizonates rhaeticus (Reinhardt) Schulz \\ Pl. 5, fig. 9 \\ Range-chart number: 36
}

1961: Aequitriradites? rhaeticus - Reinhardt, p. 709; pl. 2, fig. 3 1967: Cingulizonates rhaeticus (Reinhardt 1961) - Schulz, p. 584; pl. 13 , figs.6, 7

This species has a body encircled by a $6-10 \mu \mathrm{m}$ wide cingulum, which towards the equator passes into a 5-8 $\mu \mathrm{m}$ wide zona. The delimitation between the body and the cingulum is sharp, while the transition from the cingulum to the zona is gradual. The outer edge of the zona is sinuous. The proximal exine of the body has a laevigate to scabrate surface. The distal surface of the body and all of the cingulum is sculptured with some indistinct, irregularly spaced grooves. The zona, consisting of ektexine, is transparent, with irregularly spaced, radiating lists of thickened ektexine, and with a slightly thickened outer edge. The equatorial diameter of the illustrated specimen is $55 \mu \mathrm{m}$. This specimen was the only one recorded.

\section{Genus Limbosporites Nilsson 1958}

\section{Limbosporites lundbladii Nilsson}

Pl. 5, fig. 7

Range-chart number: 34

1958: Limbosporites lundbladii-Nilsson, p. 47; pl. 3, fig. 7 
Equatorial diameter: 40 (44) $46 \mu \mathrm{m}(\mathrm{n}=3)$.

This species is characterized by a distinct foveolate sculpturing on the distal surface of the body, and by a zona with radiating ridges of thickened exine.

\section{Genus Heliosporites Schulz 1962}

\section{Heliosporites altmarkensis Schulz}

Pl. 6, figs.1, 2

Range-chart number: 41

1962: Heliosporites altmarkensis - Schulz, p. 311; pl. 1, fig. 9; pl. 2, figs. 10,11

Equatorial diameter: 44 (50) $56 \mu \mathrm{m}(\mathrm{n}=3)$.

This species has a very conspicuous sculpture, distally and on the zona, consisting of 3-12 $\mu \mathrm{m}$ high spines of variable form. The spores are often recorded in tetrads.

Turma Monoletes Ibrahim 1933

Subturma Azonomonoletes Luber 1955

Genus Laevigatospurites Ibrahim 1933

\section{Laevigatosporites sp.}

Pl. 6, fig. 3

Range-chart number: 40

Description: Monolete spore with an elliptical to circular amb. In longitudinal, equatorial view, the distal profile is convex, while the proximal profile is concave, giving the spore a "bean-shaped" appearance. The monolete-mark is distinct, simple, and extends for about $1 / 2$ of the spore-length. The exine is laevigate to scabrate and about $1 \mu \mathrm{m}$ thick. Spore-length: 26 (35) 46 $\mu \mathrm{m}$, width: 20 (27) $35 \mu \mathrm{m}(\mathrm{n}=3)$.

\section{Genus Marattisporites Couper 1958}

\section{Marattisporites scabratus Couper}

Pl. 6, fig. 4

Range-chart number: 52

1958: Marattisporites scabratus - Couper, p. 133; pl. 15, figs.20-23

Spore-length: 20 (25) $31 \mu \mathrm{m}$, width: 16 (20) $25 \mu \mathrm{m}$. The exine is about $1 \mu \mathrm{m}$ thick, scabrate to granulate, with sparsely spaced granules.

Subturma Zonomonoletes Luber 1935

Genus Aratrisporites Leschik 1955 emend. Playford \& Dettmann, 1965

Aratrisporites minimus Schulz

Pl. 6, fig. 5

Range-chart number: 66
1967: Aratrisporites minimus - Schulz, p. 592; pl. 16, figs. 7-9

Spore-length: 23 (31) $36 \mu \mathrm{m}$, width: 16 (25) $28 \mu \mathrm{m}$. This species is characterized by having a $2-5 \mu \mathrm{m}$ wide "pseudozona" (not distinctly separated from the inner body) at the equator. The monolete-mark is distinct, sett off by sinuous elevated lips of exine and extending almost the length of the spore. The exine of the body and zona, are finely punctate to granulate.

Anteturma Pollenites Potonié 1931

Turma Saccites Erdtman 1947

Subturma Polysaccites Cookson 1947

Trisaccate, undet.

Pl. 6, fig. 6

Range-chart number: 82

Description: Trisaccate pollen. In polar view the corpus is circular, the sacci are relatively small, attached to the corpus semi-distally. The exine of the corpus is granulate, while the sacci have a thin, intrareticulate exine. The corpus-width of the illustrated specimen is about $40 \mu \mathrm{m}$. The length of the sacci are $25-30 \mu \mathrm{m}$, the width $10-15 \mu \mathrm{m}$ and the height about $15 \mu \mathrm{m}$.

Remarks: Only one specimen was recorded. It was in a bad state of preservation, with a corroded surface.

Subturma Monosaccites Potonié \& Kremp 1954

Monosaccate, undet.

Pl. 6, fig. 7

Range-chart number: 6

Description: Monosaccate pollen with a slightly elliptical to circular amb. There is an indistinct delimitation between the corpus and the surrounding saccus. Often the saccus is most wide in two opposite areas, giving the grain an elliptical amb. The exine on the corpus as well as on the saccus is irregularly reticulate.

Pollen-length: 91 (94) $96 \mu \mathrm{m}$; width: 72 (73) $73 \mu \mathrm{m}$ $(n=3)$

Remarks: Very few monosaccate pollen are described from the Jurassic Period. The specimens recorded in the present study could be reworked from older sediments, as the state of preservation is rather bad. Nevertheless, they do have a resemblance to the Early Jurassic cf. Walchia sp. Reissinger 1950 (pl. 17, fig. 22), apart from a more distinct delimitation between the corpus and the saccus of the latter.

Subturma Disaccites Cookson 1947

Genus Vitreisporites Leschik 1955 
Vitreisporites pallidus (Reissinger) Nilsson

Pl. 6, figs.8 \& 9

Range-chart number: 50

1950: Pityosporites pallidus - Reissinger, p. 109; pl. 15, figs. $1-5$

1958: Vitreisporites pallidus (Reissinger 1950) - Nilsson, p. 78; pl. 7. figs. 12-14

Pollen length: 14 (18) $21 \mu \mathrm{m}$, width: 26 (31) $37 \mu \mathrm{m}$ $(\mathrm{n}=11)$.

Bisaccate (rarely trisaccate) pollen with an elliptical outline and a characteristically small size. The corpus exine is about $0.5 \mu \mathrm{m}$ thick, scabrate to finely intrareticulate. The exine on the sacci is about $0.5 \mu \mathrm{m}$ thick and intrareticulate with luminae about $1 \mu \mathrm{m}$ in diameter. There is a weak tendency for the luminae to be radially arranged, especially near the roots of the sacci.

\section{Genus Pinuspollenites Raatz 1937 ex. Potonié 1958}

\section{Pinuspollenites minimus (Couper) Kemp}

Pl. 7, figs. $1 \& 2$

Range-chart number: 64

1958: Abietineaepollenites minimus -Couper, p. 153; pl. 28, figs.14, 15

1967: Pityosporites scaurus (Nilsson 1958) - Schulz, p. 595; pl. 17, figs. 12,13

1970: Pinuspollenites minimus (Couper 1958) - Kemp, p. 116; pl. 24, figs. $1-6$

Corpus-length: $26-46 \mu \mathrm{m}$, width: $28-50 \mu \mathrm{m}$

Sacci-length: $28-45 \mu \mathrm{m}$, width: $22-30 \mu \mathrm{m}$

Total length: 36 (41) $50 \mu \mathrm{m}$, width: 50 (57) $66 \mu \mathrm{m}$ $(n=10)$.

The corpus is relatively large, broadly elliptical to circular in polar view. The sacci are hemispherical and attached to the corpus distally. The corpus-exine is 1-2 $\mu \mathrm{m}$ thick and scabrate to finely intrareticulate. The exine of the sacci is reticulate, the luminae are 3-5 $\mu \mathrm{m}$ in diameter. $P$. minimus differs from $P$. pinoides in having sacci distinctly smaller than the corpus and in having a larger total size.

Pinuspollenites pinoides (Nilsson) Lund

Pl. 7, fig. 3

Range-chart number: 63

1958: Sulcatisporites pinoides - Nilsson, p. 86; pl. 8, figs.6, 7

1977: Pinuspollenites pinoides (Nilsson 1958) - Lund, p. 76; pl. 9, fig. 7

Corpus-length: $25-32 \mu \mathrm{m}$, width: $28-33 \mu \mathrm{m}$, height: about $26 \mu \mathrm{m}$.

Sacci-length: $20-25 \mu \mathrm{m}$, width: $23-26 \mu \mathrm{m}$, height: about $25 \mu \mathrm{m}$.

Total length: 26 (33) $43 \mu \mathrm{m}$, width: 40 (47) $56 \mu \mathrm{m}$ $(\mathrm{n}=10)$.

The sacci are more than hemispherical, nearly as large as the corpus, and attached distally. The corpus-exine is $2 \mu \mathrm{m}$ thick and has a dense sculpture of low, partly fused, verrucae. The exine of the sacci is intrareticulate with luminae $1-2 \mu \mathrm{m}$ in diameter.

Genus Podocarpidites Cookson 1947 emend. Potonié 1958

Podocarpidites cf. biformis Rouse

Pl. 8, fig. 6

Range-chart number: 7

Description: Bisaccate pollen with a relatively small corpus, circular when seen in polar view. The sacci are large, kidney-shaped and attached to the corpus distally. The sulcus is about $7 \mu \mathrm{m}$ wide. The corpus-exine of the sacci has a less dense intrareticulate structure with a tendency towards a radiating arrangement of the luminae.

Corpus-length: $23-30 \mu \mathrm{m}$, width: $25-30 \mu \mathrm{m}$

Sacci-length: $35-39 \mu \mathrm{m}$, width: $26-28 \mu \mathrm{m}$

Total length: 35 (39) $44 \mu \mathrm{m}$, width: 62 (63) $65 \mu \mathrm{m}$ $(\mathrm{n}=3)$.

Remarks: The recorded specimen differs from the pollen of $P$. biformis, originally described by Rouse (1957), in having a more delicate sculpturing and a smaller size (total width of $P$. biformis was stated as 75-90 $\mu \mathrm{m})$.

\section{Genus Protopinus Bolkhovitina 1956}

\section{Protopinus cf. scanicus Nilsson}

Pl. 7, fig. 8

Range-chart number: 9

Description: Bisaccate pollen with a broad, elliptical outline. The corpus is broad elliptical in polar view, with the shortest axis parallel to the longest axis of the grain. The sacci are attached distally to equatorially; the delimitation between the corpus and the sacci is indistinct. The sacci are connected to each other by some 2-8 $\mu \mathrm{m}$ wide, equatorial ridges of thickened exine. The sulcus is $10-18 \mu \mathrm{m}$ wide. The corpus-exine is 1-2 $\mu \mathrm{m}$ thick, finely intrareticulate, with a lumen-diameter of $0.5-1.0 \mu \mathrm{m}$. The exine of the sacci has a less dense intrareticulate structure, with a lumen-diameter of 2-4 $\mu \mathrm{m}$.

Pollen-length: 56 (57) $59 \mu \mathrm{m}$, width: 86 (91) $95 \mu \mathrm{m}$ $(\mathrm{n}=3)$.

Remarks: The specimens recorded in the present study, referred to Protopinus cf. scanicus, are rather small compared to the pollen of $P$. scanicus originally described by Nilsson (1958), where the total width was stated as $100-116 \mu \mathrm{m}$.

Genus Alisporites Daugherty 1941 
Alisporites robustus Nilsson

Pl. 8, fig. 2

Range-chart number: 20

1958: Alisporites robustus - Nilsson, p. 82; pl. 8, figs.2, 3

Corpus-length: 40-72 $\mu \mathrm{m}$, width: $33-56 \mu \mathrm{m}$.

Sacci-length: $40-73 \mu \mathrm{m}$, width: $36-53 \mu \mathrm{m}$.

Total length: 40 (60) $72 \mu \mathrm{m}$, width: 66 (81) $92 \mu \mathrm{m}$ $(\mathrm{n}=10)$.

Seen in polar view the corpus is broadly elliptical with the shortest axis parallel to the longest axis of the grain. The sacci are hemispherical, approximately of the same size as the corpus, and attached to the corpus semidistally to equatorially. The roots of the sacci are indistinct. The corpus-exine is finely intrareticulate with a lumen-diameter about $1 \mu \mathrm{m}$. The exine of the sacci has an irregular, intrareticulate structure with a lumendiameter of about $4 \mu \mathrm{m}$, and with a tendency towards a radiating arrangement of the luminae (most distinct near the roots of the sacci).

\section{Alisporites radialis (Leschik) Lund}

PI. 8, fig. 1

Range-chart number: 31

1955: Cunaetisporites radialis - Leschik, p. 66; pl. 10, fig. 6

1977: Alisporites radialis (Leschik 1955) - Lund, p. 75; pl. 9, figs 3,4

Corpus-length: $50-72 \mu \mathrm{m}$, width: $28-52 \mu \mathrm{m}$.

Sacci-length: 53-76 $\mu \mathrm{m}$, width: $26-48 \mu \mathrm{m}$.

Total length: 53 (61) $71 \mu \mathrm{m}$, width: 63 (72) $85 \mu \mathrm{m}$ $(\mathrm{n}=10)$.

$A$. radialis is very similar to $A$. robustus but differs in having sacci larger than the corpus and distinct sacciroots.

Alisporites thomasii (Couper) Nilsson

Pl. 8, fig. 3

Range-chart number: 78

1958: Pteruchipollenites thomasii-Couper, p. 150; pl. 26, figs.10-12 1958: Alisporites thomasii (Couper 1958) - Nilsson, p. 83; pl. 8, fig. 1

Corpus-length: $32-47 \mu \mathrm{m}$. Total length: 33 (42) $51 \mu \mathrm{m}$, width: 50 (61) $76 \mu \mathrm{m}(\mathrm{n}=7)$.

The corpus-exine is thin, finely intrareticulate to punctate. The exine of the sacci has a finely intrareticulate structure with a lumen-diameter about $2 \mu \mathrm{m}$ and a tendency towards a radiating pattern. A. thomasii differs from $A$. robustus and $A$. radialis in having a smaller size, an approximately circular and relatively larger corpus (compared to the sacci), and a thinner, finely sculptured, exine.

\section{Alisporites grandis (Cookson) Dettmann}

PI. 8, fig. 5

Range-chart number: 17
1953: Disaccites grandis - Cookson, p. 471. pl. 2, fig, 41

1963: Alisporites grandis (Cookson 1953) - Dettmann, p. 102; pl. 25, figs. 1-4

Corpus-length: 50-88 $\mu \mathrm{m}$, width: 51-70 $\mu \mathrm{m}$.

Sacci-length: $51-88 \mu \mathrm{m}$, width: $33-65 \mu \mathrm{m}$.

Total length: 50 (73) $88 \mu \mathrm{m}$, width: 102 (117) $155 \mu \mathrm{m}$ $(\mathrm{n}=7)$.

The corpus-exine is about $1.5 \mu \mathrm{m}$ thick, with a finely intrareticulate structure. The exine of the sacci is 1-2 $\mu \mathrm{m}$ thick and has a less dense intrareticulate structure. This species differs from the other species referred to the genus Alisporites in having a larger size.

\section{Alisporites microsaccus (Couper) Pocock \\ P1. 8, fig. 4 \\ Range-chart number: 76}

1958: Pteruchipollenites microsaccus - Couper, p. 151; pl. 26, fig. 13 1962: Alisporites cf. A. microsaccus (Couper 1958) - Pocock, p. 61; pl. 9, figs.138, 139

Corpus-length: 46-95 $\mu \mathrm{m}$, width: $36-63 \mu \mathrm{m}$.

Sacci-length: $46-95 \mu \mathrm{m}$, width: $18-45 \mu \mathrm{m}$.

Total length: 46 (74) $92 \mu \mathrm{m}$, width: 43 (62) $86 \mu \mathrm{m}$ $(n=6)$.

The corpus-exine is scabrate, while the exine of the sacci has a finely reticulate structure. This species differs from the other species of the genus Alisporites in having an elliptical outline with the shortest axis in the width of the grain, and in having relatively small sacci attached to the corpus distally. The specimens recorded are rather large compared to the size-range given by Couper (1958), but corresponds with the size-range given by Pocock (1962).

Genus Quadraeculina Maljavkina 1949

Quadraeculina anellaeformis Maljavkina

Pl. 7, fig. 7

Range-chart number: 48

1949: Quadraeculina anellaeformis - Maljavkina, p. 110; pl. 39, fig. 3

Pollen-length: 43 (57) $73 \mu \mathrm{m}$, width: 33 (47) $60 \mu \mathrm{m}$ $(\mathrm{n}=10)$.

These pollen have a characteristically quadrangular to rectangular outline with rounded angles. The reduced sacci are attached distally and tend to coalesce at their ends, so that in some specimens they appear to encircle the corpus. Between the sacci is a distinct and wide rectangular sulcus. Equatorially, immediately above and parallel to the sacci, there are another two longitudinal areas with thin exine. The exine of the corpus, as well as of the sacci, is intrareticulate; the lumen-diameter is $1-2 \mu \mathrm{m}$ on the saccus, less on the corpus.

Genus Schismatosporites Nilsson 1958 


\section{Schismatosporites ovalis Nilsson}

Pl. 7, fig. 6

Range-chart number: 65

1958: Schismatosporites ovalis - Nilsson, p. 87; pl. 8, fig. 9

Pollen-length: 47 (60) $80 \mu \mathrm{m}$, width: 77 (90) $99 \mu \mathrm{m}$ $(\mathrm{n}=6)$.

Equatorially, at the delimitation between the corpus and the sacci, is a small elevation. The exine of the corpus is finely intrareticulate, the sacci-exine is less dense intrareticulate with a lumen-diameter of $2 \mu \mathrm{m}$.

\section{Genus Umbrosaccus Mädler 1964}

\section{Umbrosaccus keuperianus Mädler \\ Pl. 7, fig. 4 \\ Range-chart number: 70}

1964b: Umbrosaccus keuperianus - Mädler, p. 118; pl. 11, figs.5, 8

Corpus-length: $32-43 \mu \mathrm{m}$, width: $31-57 \mu \mathrm{m}$.

Sacci-length: $45-56 \mu \mathrm{m}$, width: $26-46 \mu \mathrm{m}$.

Total length: 44 (50) $56 \mu \mathrm{m}$, width: 76 (82) $92 \mu \mathrm{m}$ $(\mathrm{n}=5)$.

The corpus is circular to rhomboid when seen in polar view. The relatively large sacci are more than hemispherical, attached to the corpus equatorially, nearly encircling the corpus. The corpus-exine is intrapunctate to -scabrate, the exine of the sacci is intrareticulate with a tendency towards a radiating arrangement of the luminae.

\section{Cf. Umbrosaccus}

Pl. 7, fig. 5

Range-chart number: 37

Description: Bisaccate pollen with relatively large, more than hemispherical sacci and a small, circular to rhomboid corpus (when seen in polar view). The sulcus is only about $3 \mu \mathrm{m}$ wide. The corpus-exine is relatively thick and intrapunctate. The exine of the sacci is intrareticulate with a lumen-diameter up to $5 \mu \mathrm{m}$. The corpus-length is about $65 \mu \mathrm{m}$ for the illustrated specimen, the width about $55 \mu \mathrm{m}$. The sacci-length is $95 \mu \mathrm{m}$, the width about $70 \mu \mathrm{m}$. The total length is $95 \mu \mathrm{m}$, the width $140 \mu \mathrm{m}$.

Remarks: Only one specimen was recorded. It is comparable to the genus Umbrosaccus in all characters except for the large size.

Turma Aletes Ibrahim 1933

Subturma Azonaletes (Luber 1935) Potonié \& Kremp 1954

Genus Araucariacites Cookson 1947 ex Couper 1953
Araucariacites australis Cookson 1947

Pl. 9, fig. 1

Range-chart number: 57

1949: Granulonapites (Araucariacites) australis - Cookson, p. 130; pl. 13 , figs. $1-4$

Diameter: 46 (69) $99 \mu \mathrm{m}(\mathrm{n}=10)$.

Spherical, though often secondarily folded. The exine is thin with a scabrate to finely granulate sculpturing.

\section{Genus Perinopollenites Couper 1958}

The genus Perinopollenites includes more or less spherical, alete pollen with an exine which is completely separated into a body of endexine enclosed by a very thin, membraneous ektexine.

\section{Perinopollenites elatoides Couper}

Pl. 9, fig. 2

Range-chart number: 54

1958: Perinopollenites elatoides - Couper, p. 152; pl. 27, figs. 9-11

Total diameter: 26 (32) $37 \mu \mathrm{m}(\mathrm{n}=10)$.

The size of the body in relation to the total size is very variable.

Genus Cupressacites (Bolkhovitina 1956) Krutzsch 1971

\section{Cupressacites sp.}

Pl. 9, fig. 3

Range-chart number: 51

Description: Spherical, though often secondarily folded. The exine is very thin $(0.5-1.0 \mu \mathrm{m})$, transparent, and laevigate. Diameter: 31 (39) $50 \mu \mathrm{m}(\mathrm{n}=11)$.

\section{Genus Cerebropollenites Nilsson 1958}

Cerebropollenites macroverrucosus (Thiergart) Schulz Pl. 9 , figs. 4 \& 5

Range-chart number: 72

1949: Pollenites macroverrucosus - Thiergart, p. 17; pl. 2, fig. 19

1967: Cerebropollenites macroverrucosus (Thiergart 1949) - Schulz, p. 603 ; pl. 21 , figs, $4-6$

Equatorial diameter: 41 (48) $56 \mu \mathrm{m}(\mathrm{n}=12)$.

Alete pollen with a more or less circular outline. The exine is sculptured with densely arranged, hollow, and often elongated verrucae, 4-6 $\mu \mathrm{m}$ in diameter. In a circular area (16-20 $\mu \mathrm{m}$ in diameter) the exine is thin and the sculpture reduced. This species differs from $C$. thiergartii in having larger, non-solid, and un-fused sculptural elements. 
Cerebropollenites thiergartii Schulz

Pl. 9, fig. 7

Range-chart number: 62

1967: Cerebropollenites thiergartii-Schulz, p. 603; pl. 21, figs. 7, 8

Equatorial diameter: $46(52) 62 \mu \mathrm{m}(\mathrm{n}=10)$.

The exine is sculptured with small, solid verrucae or granulae, 1-4 $\mu \mathrm{m}$ in diameter, and partly fused at the base.

\section{Genus Spheripollenites Couper 1958}

Couper described this genus as "probably monoporate". In the present study no convincing pores were observed, thus the genus is here referred to Turma Aletes.

\section{Spheripollenites psilatus Couper}

Pl. 9, fig. 9

Range-chart number: 69

1958: Spheripollenites psilatus - Couper, p. 159; pl. 31, figs. 4-8

Diameter: 17 (24) $30 \mu m(n=12)$.

Spherical, though frequently secondarily folded. The exine is $1.0-1.5 \mu \mathrm{m}$ thick and laevigate.

\section{Spheripollenites subgranulatus Couper}

Pl. 9, fig. 8

Range-chart number: 83

1958: Spheripollenites subgranulatus - Couper, p. 158; pl. 31 , figs.9-11

Diameter: 18 (23) $29 \mu \mathrm{m}(\mathrm{n}=12)$.

Similar to $S$. psilatus apart from a finely granulate sculpturing. According to Schulz (1967) this species often occurs in clusters. This tendency was not observed in the present study.

\section{Genus Exesipollenites Balme 1957}

\section{Exesipollenites tumulus Balme}

Pl. 9, fig. 6

Range-chart number: 68

1957: Exesipollenites tumulus - Balme, p. 39; pl. 11, figs. 123-125

Equatorial diameter: $23(28) 33 \mu \mathrm{m}(\mathbf{n}=10)$.

The exine is laevigate to scabrate and about $2 \mu \mathrm{m}$ thick. In a circular or triangular area the exine is thickened and in the middle of the thickened area is a circular depression, 4-7 $\mu \mathrm{m}$ in diameter, of thinner exine.

Subturma Zonaletes Luber 1935 emend. Potonié 1958

Genus Callialasporites Dev 1961
The genus Callialasporites comprises alete pollen with a lensoid shape and a circular, convex triangular or trilobate outline. The exine is differentiated into two layers. The ektexine forms a zona, and on the rest of the surface the exine-layers are partly fused, often resulting in variable patterns of folding.

\section{Callialasporites microvelatus Schulz}

Pl. 10, fig. 1

Range-chart number: 86

1966: Callialasporites microvelatus - Schulz, p. 136; pl. 7, figs. 1, 2

The outline is circular. The ektexine forms a narrow zona, 3-5 $\mu \mathrm{m}$ wide. On the rest of the surface the two exine layers are partly fused. The body is circular with a diameter of about $7 / 8$ of the total grain-diameter. The endexine is about $2 \mu \mathrm{m}$ thick, intrareticulate to finely intragranulate. The ektexine is transparent, about $1 \mu \mathrm{m}$ thick, and finely intragranulate. Both the endexine and the ektexine are unfolded. The equatorial diameter of the illustrated specimen is $58 \mu \mathrm{m}$. This species differs from the other species referred to Callialasporites in having an endexine that is thicker than the ektexine, a very narrow zona, and an absence of primary folds. Only one specimen was recorded.

\section{Callialasporites trilobatus (Balme) Dev}

Pl. 10, fig. 2

Range-chart number: 94

1957: Zonalapollenites trilobatus - Balme, p. 33; pl. 8, figs.91, 92 1961: Callialasporites trilobatus (Balme 1957) - Dev, p. 48; pl. 4 figs. 28,29

The outline is triangular with convex sides. The body is rounded triangular, the diameter is $2 / 3$ to $3 / 4$ of the total diameter. The endexine is $1-2 \mu \mathrm{m}$ thick, scabrate to finely intragranulate. The ektexine is finely granulate. The ektexine forms a trilobate zona and on the rest of the surface it is partly fused with the endexine resulting in both randomly orientated and radiating folds. The equatorial diameter of the illustrated specimen is 54 $\mu \mathrm{m}$. Only one specimen was recorded. C. trilobatus differs from the other species referred to Callialasporites in having a trilobate zona.

Callialasporites segmentatus (Balme) Srivastava Pl. 10, fig. 3

Range-chart number: 87

1957: Zonalapollenites segmentatus - Balme, p. 33; pl. 9, figs.93, 94 1963: Callialasporites segmentatus (Balme 1957) - Srivastava, p. 1323

Equatorial diameter: 54 (56) $58 \mu \mathrm{m}(\mathrm{n}=4)$.

The outline is circular. The endexine is $1-2 \mu \mathrm{m}$ thick, finely punctate, and forms a circular body with a diameter about $7 / 8$ of the total diameter. The ektexine is about 
$1 \mu \mathrm{m}$ thick, and laevigate to finely punctate. The ektexine is partly fused with the endexine, resulting in small, randomly orientated folds all over the grain. This species differs from the other species referred to Callialasporites in having a relatively larger body and a conspicuous randomly orientated folding.

Turma Plicates (Naumova 1939) Potonié 1960

Subturma Monocolpates Iversen \& Troels-Smith 1950

Genus Chasmatosporites Nilsson 1958 emend. Pocock \& Jansonius 1969

Chasmatosporites apertus (Rogalska) Nilsson

PI. 10, figs. $7 \& 8$

Range-chart number: 55

1954: Pollenites apertus - Rogalska, p. 45; pl. 12, figs. 13-15

1958: Chasmatosporites apertus (Rogalska 1954) - Nilsson, p. 56; pl. 4 , figs. 5,6

Equatorial diameter: $30(34) 46 \mu \mathrm{m}(\mathrm{n}=11)$.

The outline is circular. The colpus is wide open, elliptical to circular; the colpuslength is about $2 / 3$ of the total diameter. The exine is $2-4 \mu \mathrm{m}$ thick, tectate with an indistinct intrareticulate sculpturing. This species differs from $C$. hians in having a smaller size, from $C$. elegans in having a more circular outline, and from both in having a very thick exine.

Chasmatosporites elegans Nilsson

PI. 10, figs. 5 \& 6

Range-chart number: 56

1958: Chasmatosporites elegans - Nilsson, p. 58; pl. 4, figs. 11,12

Total length: 35 (44) $50 \mu \mathrm{m}$, width: 30 (37) $46 \mu \mathrm{m}$ $(n=10)$.

The outline is elliptical. The colpus is more or less wide open, elliptical to triangular. The exine is $0.5-1.0 \mu \mathrm{m}$ thick, tectate with a regular micro-intrareticulum. This species differs from $C$. hians in having a smaller size, an elliptical outline, a thinner exine and a regular microintrareticulum.

\section{Chasmatosporites hians Nilsson \\ PI. 10, fig. 4 \\ Range-chart number: 59}

1958: Chasmatosporites hians - Nilsson, p. 55; pl. 4, figs. 3, 4

Total length: 46 (57) $73 \mu \mathrm{m}$, width: 37 (45) $51 \mu \mathrm{m}$ $(\mathrm{n}=11)$.

The outline is circular to elliptical. The colpus is circular to elliptical, wide open, and extends for about $2 / 3$ of the total diameter. The exine is $1-2 \mu \mathrm{m}$ thick, tectate with a distinct, irregular, nearly vermiculate microintrareticulum.
Genus Ricciisporites Lundblad 1954 emend. Lundblad 1959

\author{
Ricciisporites tuberculatus Lundblad \\ Pl. 11, fig. 1 \\ Range-chart number: 46
}

1954: Ricciisporites tuberculatus - Lundblad, p. 401; pl. 4, figs. 8,9

Length of single grain: 66 (68) $72 \mu \mathrm{m}$, width: 54 (59) 65 $\mu \mathrm{m}$.

Length of tetrad: 70 (91) $115 \mu \mathrm{m}$, width: 61 (72) $83 \mu \mathrm{m}$ $(\mathrm{n}=11)$.

This species usually occurs in tetrads. The single pollen-grain has an elliptical outline. The distal colpus is elongate, narrow in the middle and extends almost the entire length of the grain. The exine is 1.5-2.0 $\mu \mathrm{m}$ thick and sculptured with densely spaced clavae, baculae, and verrucae. The sculptural elements vary in size and shape from specimen to specimen. Some grains appear laevigate, others have very large clavae up to $8 \mu \mathrm{m}$ high, $16 \mu \mathrm{m}$ wide.

Genus Monosulcites Cookson 1947 ex. Couper 1953

\section{Monosulcites minimus Cookson}

Pl. 10, fig. 9

Range-chart number: 53

1947: Monosulcites minimus - Cookson, p. 135; pl. 15, figs. 47-50

Total length: 30 (36) $39 \mu \mathrm{m}$, width: 20 (23) $27 \mu \mathrm{m}$ $(\mathrm{n}=12)$.

The outline is elliptical with rounded or slightly pointed ends. The colpus extends the entire length of the grain. The exine is laevigate, about $1 \mu \mathrm{m}$ thick. Cookson (1947) erected $M$. minimus encompassing tertiary specimens. Couper (1958) stated that specimens recorded from Jurassic and Cretaceous strata in New Zealand and Britain appeared indistinguishable from Cookson's specimens, and thus referred the Mesozoic specimens to $M$. minimus, which is followed here.

Monosulcites punctatus Orlowska-Zwolinska

Pl. 10, fig. 10

Range-chart number: 58

1966: Monosulcites punctatus - Orlowska-Zwolinska, p. 1015; pl. 9, fig. 46

Total length: 43 (59) $73 \mu \mathrm{m}$, width: 26 (33) $40 \mu \mathrm{m}$ $(\mathrm{n}=8)$.

The outline is elongated, elliptical with pointed ends ("spindle-shaped"). The colpus is narrow and extends the entire length of the grain. The exine is $0.5-1.0 \mu \mathrm{m}$ thick and has a finely intrapunctate structure. This species differs from Chasmatosporites elegans in having 
a more elongated amb, pointed ends, and a thinner exine.

Monosulcites cf. punctatus Orlowska-Zwolinska

Pl. 11, fig. 3

Range-chart number: 49

Description: The recorded specimens are identical with Monosulcites punctatus erected by Orlowska-Zwolinska 1966, except for having layers of thin exine that form longitudinal folds.

Total length: 50 (56) $66 \mu \mathrm{m}$, width: 20 (24) $27 \mu \mathrm{m}$ $(n=8)$.

Remarks: The specimens recorded compare very well with the specimens illustrated by Lund (1977).

\section{Genus Clavatipollenites Couper 1958}

\section{Clavatipollenites hughesii Couper}

Pl. 11, fig. 2

Range-chart number: 77

1958: Clavatipollenites hughesii-Couper, p. 159; pl. 31, figs. 19-22

Total length: 23 (28) $33 \mu \mathrm{m}$, width: 23 (26) $28 \mu \mathrm{m}$ $(\mathrm{n}=8)$.

C. hughesii includes small monocolpate pollen with an elliptical to circular outline. The exine is $1.0-1.5 \mu \mathrm{m}$ thick, tectate, with a laevigate surface.

\section{Subturma Praecolpates Potonié \& Kremp 1954}

Genus Eucommiidites Erdtman 1948 emend. Hughes 1961

Erdtman (1948) and Couper (1958) described the genus Eucommiidites as tricolpate. Hughes (1961) interpreted the two narrow "side-colpi" as one ring-furrow which is more or less reduced near the ends of the grain. Hughes therefore referred this genus to Subturma Praecolpates, which is followed here.

\section{Eucommiidites minor Groot \& Penny}

Pl. 11, fig. 5

Range-chart number: 75

1960: Eucommiidites minor - Groot \& Penny, p. 234; pl. 2, fig. 14

Total length: 22 (27) $30 \mu \mathrm{m}$, width: 20 (21) $24 \mu \mathrm{m}$ $(\mathrm{n}=5)$.

The outline is circular to elliptical. Distally there is a distinct colpus, that is narrow in the middle, expands at the ends, and extends almost the entire length of the grain. On the proximal side is a ring-furrow which is more or less reduced near the ends of the grain, giving the appearance of two "side-colpi". The exine is laevigate and about $2 \mu \mathrm{m}$ thick. Groot \& Penny (1960) described this species as "Tricolpate (?)".
Eucommiidites troedssonii Erdtman

Pl. 11, fig. 4

Range-chart number: 32

1948: Eucommiidites troedssonii - Erdtman, p. 267; figs.5-10, 13-15

Total length: 33 (36) $38 \mu \mathrm{m}$, width: 23 (24) $27 \mu \mathrm{m}$ $(\mathrm{n}=5)$. The exine is about $1 \mu \mathrm{m}$ thick, laevigate to intrapunctate. $E$. troedssonii is similar to $E$. minor apart from the larger size and thinner exine.

Turma Poroses (Naumova 1939) Potonié 1960

Subturma Monoporines Naumova 1939

Genus Corollina Maljavkina 1949 emend. Cornet \& Traverse 1975

1949: Corollina Maljavkina

1949: Circulina Maljavkina

1953: Classopollis Pflug

1958: Classopollis Pflug emend. Couper

1960: Corollina Maljavkina emend. Klaus

1968: Circulina Maljavkina emend. Klaus

1961: Classopollis Pflug emend. Pocock \& Jansonius

1969: Classopollis Pflug emend. Reyre

1975: Corollina Maljavkina emend. Cornet \& Traverse

1976: Classopollis Pflug emend. Srivastava

This long list of synonyms reflects both the deep disagreement concerning the first legitimate name for this genus and the gradually improved interpretation of the morphological characters, that has resulted in several emended diagnoses of the genus. The genus-name $\mathrm{Co}$ rollina Maljavkina 1949 was correctly established, even though the descriptions of both the genus and the belonging species were very weak and thus difficult to use. Cornet \& Traverse (1975) discuss the establishment of the younger generic-names and conclude that Circulina Maljavkina 1949 and Corollina Maljavkina 1949 should be combined into a single genus, named Corollina, with Classopollis as a junior synonym. They proposed a new genus-description based on a neo-type, as Maljavkina"s genotype (Corollina compacta) is not preserved. In addition there is still doubt about whether the distal "pseudopore" is a real pore (functioning as a germinal opening), and thus whether the genus should be referred to Turma Poroses, Subturma Monoporines. However, there is no better alternative in the systematic system used here.

Corollina torosus (Reissinger) Klaus emend. Cornet \& Traverse

Pl. 11, figs. 6-8

Range-chart number: 30

1950: Pollenites torosus - Reissinger, p. 115; pl. 14, fig. 20

1958: Classopollis torosus (Reissinger 1950)-Couper, p. 156; pl. 28, figs.2-7

1960: Corollina (al. Pollenites) torosus (Reissinger 1950) - Klaus, p. 168

1975: Corollina torosus (Reissinger 1950) - Klaus 1960 emend. Cornet \& Traverse, p. 17 ; pl. 5, figs. $2-9,14$ 
Equatorial diameter: 23 (29) $33 \mu \mathrm{m}(\mathrm{n}=20)$.

Monoporate (?), more or less spherical pollen, frequently occurring in tetrads. At the proximal pole is a tetrad-scar that appears as a small triangular area of thin exine or as a small trilete-mark. At the equator is a 5-13 $\mu \mathrm{m}$ wide band of thickened exine. The band is composed of columellae, fused to form 6-10 parallel endexinal ribs. Semidistally, parallel to the equator, is a ring of thin exine, a ring-furrow, and at the distal pole is an, often indistinct, "pseudopore", 4-9 $\mu \mathrm{m}$ in diameter. The exine is tectate, $1-3 \mu \mathrm{m}$ thick with a homogenous, laevigate to scabrate outer layer covering the total surface, and an inner, structured layer of varying thickness and structure. This innerlayer is thin at the proximal tetrad-scar, at the semidistal ring-furrow, and at the distal "pseudo-pore", while it is thickened at the equatorial band.

\section{Corollina sp. 1}

Pl. 11, fig. 9

Range-chart number: 91

Description: Monoporate (?), more or less spherical pollen (not seen in tetrads). At the proximal pole is a tetrad-scar, appearing as a small, triangular area of thin exine. At the equator is a band of thickened exine. The band is composed of columellae, fused to $6-8$ endexinal ribs. Semidistally, parallel to the equator, is a ring of thin exine, a ring-furrow, and at the distal pole is an, often indistinct, "pseudo-pore". The exine is 1.5-2.0 $\mu \mathrm{m}$ thick, tectate, and with small, hair-like micro-echinae on the surface $(<1 \mu \mathrm{m}$ high).

Equatorial diameter: 30 (31) $34 \mu \mathrm{m}(\mathrm{n}=10)$.

Remarks: This species deviates from Classopollis echinatus Burger 1965, in being somewhat larger (C. echinatus is $24-26 \mu \mathrm{m}$ in diameter) and in having more endexinal ribs (C. echinatus has 3-5). Classopollis hammenii Burger 1965 also has fewer endexinal ribs while Classopollis rarus Reyre 1970 has a denser sculpturing than the recorded specimens. Corollina sp. 2 of Lund \& Pedersen (1985) compare rather well with the specimens recorded in the present study, except for a larger size (about $40 \mu \mathrm{m}$ in diameter).

Corollina sp. 2

Pl. 11, fig. 10

Range-chart number: 92

Description: Monoporate (?), more or less spherical pollen (not seen in tetrads). At the proximal pole is a tetrad-scar, appearing as a small, triangular area of thin exine. At the equator is a band of thickened exine that appears as a rather homogenous cingulum. Semidistally, parallel to the equator, is a ring of thin exine, a ring-furrow, and at the distal pole is an indistinct "pseudo-pore". The grains are very dark so the exine- structure is indistinct. The surface is sculptured with hair-like micro-echinae $(<1 \mu \mathrm{m}$ high).

Equatorial diameter: $22(24) 26 \mu \mathrm{m}(\mathrm{n}=4)$.

\section{Aquatic palynomorphs}

\section{Dinoflagellata}

In the range-chart the occurrences of the RhaetianEarly Jurassic dinoflagellate-cyst species Dapcodinium priscum, Liasidium variabile and Nannoceratopsis gracilis are shown. All other recorded dinoflagellate-cysts are grouped into "various dinoflagellate-cysts" (no. 107 in the range-chart). The dinoflagellate-cyst species recorded from zone $\mathrm{D}$ and $\mathrm{E}$ are shown in figure 7 together with their references. See Lentin \& Williams (1985) for further information concerning these species.

Division Pyrrhophyta Pascher 1914

Class Dinophyceae Fritsch 1929

Order Dinophysiales Lindemann 1928

Genus Nannoceratopsis Deflandre 1938 emend. Piel \& Evitt 1980

Nannoceratopsis gracilis Alberti emend. Evitt

Pl. 13, fig. 5

Range-chart number: 105

1961: Nannoceratopsis gracilis - Alberti, p. 30; pl. 7, figs. 16, 17 1962: Nannoceratopsis gracilis (Alberti 1961) - Evitt, p. 1129-1130

Order Peridiniales Haeckel 1894

Genus Dapcodinium Evitt 1961 emend. Dörhöfer \& Davies 1980

\section{Dapcodinium priscum Evitt}

Pl. 13, fig. 7

Range-chart number: 96

1961: Dapcodinium priscum - Evitt, p. 996-1001; pl. 119, figs. 1-14, text-figs. $1-20$

The Gassum No. 1-borehole is the type-locality for this species. Evitt (1961) recorded D. priscum from the Gassum No. 1-borehole, in the core 1440 m - 1434 m (Early Sinemurian (Michelsen 1975)). In the present study this species was recorded from sample GA-3 (1534 m) to GA-26 (1420 m) (latest Rhaetian to Early Sinemurian (Sorgenfrei \& Buch 1964, Michelsen 1975).

Genus Liasidium Drugg 1978

Liasidium variabile Drugg

Pl. 13, fig. 6

Range-chart number: 104 
1978: Liasidium variabile - Drugg, p. 69; pl. 4, fig. 10, pl. 5, figs. 1-9

In the rich material of this species the epicyst is usually conical in outline, but "shoulders" are present in some of the specimens. A reduced second antapical horn is developed on some specimens, but in most cases only one antapical horn is present. The specimen illustrated by Woollam \& Riding (1983) is very similar to the present material. Forms informally assigned as "Liassogonyaulax complexa" by Morbey (1978) are also closely similar.

\section{Acritarcha}

The specimens referred to Group Cryptarcha and Group Acritarcha have not been defined to a lower taxa than Subgroup, though eventually to genus-level.

Group Cryptarcha Diver \& Peat 1979

Subgroup Sphaeromorphitae Downie, Evitt \& Sarjeant 1963

Genus Halosphaeropsis Mädler 1963

Pl. 12, fig. 2

Genus Leiosphaeridia Eisenack 1958

Pl. 12, fig. 1

The two genera Halosphaeropsis and Leiosphaeridia are united in the range-chart as Sphaeromorphitae, no. 97.

Group Acritarcha (Evitt 1963) Diver \& Peat 1979 Subgroup Acanthomorphitae Downie, Evitt \& Sarjeant 1963

Genus Micrhystridium Deflandre 1937 emend. Sarjeant 1967

Examples:

Type 1) Pl. 12, fig. 4

Type 2) Pl. 12, fig. 5

Type 3) PI. 12, fig. 6

Type 4) PI. 12, fig. 8

Type 5) Pl. 12, fig. 9

All specimens referred to the genus Micrhystridium are united in the range-chart as Acanthomorphitae, nr. 95.

Subgroup Polygonomorphitae Downie, Evitt \& Sarjeant 1963

Genus Veryhachium Deunff 1958 emend. Downie \& Sarjeant 1963

Pl. 12, fig. 3
The genus Veryhachium constitutes the Subgroup Polygonomorphitae, nr. 98 in the range-chart.

Subgroup Herkomorphitae Downie, Evitt \& Sarjeant 1963

This acritarch-subgroup is not illustrated at the plates because of their poor state of preservation.

Range-chart number: 102

Subgroup Netromorphitae Downie, Evitt \& Sarjeant 1963

Remarks: This acritarch-subgroup is not illustrated at the plates because of their poor state of preservation. Range-chart number: 100

Subgroup Pteromorphitae Downie, Evitt \& Sarjeant 1963

Genus Pterospermopsis Wetzel 1952

Pl. 13, fig. 2

Range-chart number: 103

The fossil genus Pterospermopsis resembles the living genus Pterosperma, referred to division Chlorophyta (the green algae) (Tappan 1980, p. 808).

\section{Tasmanitids}

Division Chlorophyta Pascher 1914

Class Chlorophyceae Kützing 1843

Family Tasmanaceae Sommer 1956

Genus Tasmanites Newton 1875

Examples:

Type 1) Pl. 13, fig. 1

Type 2) Pl. 13, fig. 3

Type 3) Pl. 13, fig. 4

All specimens referred to the genus Tasmanites are united in the range-chart as Tasmanites sp., no. 99. Because of the taxonomic problems in the Tasmanitids, all specimens recorded in the present study have been included in the genus Tasmanites.

\section{Botryococcales}

Division Chlorophyta Pascher 1914

Class Chlorophyceae Kützing 1843

Family Botryococcaceae Wille 1909

Genus Botryococcus Kützing 1849

Pl. 13, fig. 8

Range-chart number: 101 
Botryococcus is a limnic-brackish, planktonic, colonial green algae. It ranges from Precambrian to present, known under different names, among those Gloecapsomorpha, Elaeophyton, Epopalaia and Reinschia. The genus Botryococcus has earlier been referred to Division Cyanophyta (the blue-green algaes) and to Division Xanthophyta (the yellow-green algaes) (Tappan 1980).

\section{Foraminiferal test-linings}

Pl. 12, fig. 7

Range-chart number: 106

The recorded foraminiferal test-linings consist of a chitinous, acid-resistant layer, originally covering the innerside of the foraminiferal test. The calcareous parts of the test have been dissolved. 


\section{Palynostratigraphy}

\section{Definition of zones}

Based on the stratigraphic range and the abundance of the miospores (microspores and pollen), the studied section has been divided into five biozones, $\mathrm{A}$ to $\mathrm{E}$ (see the range chart and figure 5 and 9). The zonation is partly based on the appearance of stratigraphically important taxa, and partly on variations in the relative abundances of specific taxa or morphological groups (figure 10). The zones are discussed below, and their vertical ranges in the Gassum No. 1-borehole are stated, together with the sample numbers.

\section{Zone A}

(GA-1 to GA-3) (1538 m to $1533 \mathrm{~m}$ ).

No definite base of this zone was recognized in the present study. It was not even possible to define the base of zone A with the help of the zonation defined in earlier studies, as the Rhaetian microspores that define the zonal-boundaries were not recorded.

In general, the trilete spores show an overwhelming dominance $(78-87 \%$ of all miospores, see fig. 10), among which the genera Deltoidospora and Baculatisporites constitute the major part. Among the mainly Rhaetian types recorded are Cingulizonates rhaeticus, Ricciisporites tuberculatus, Limbosporites lundbladii, Triancoraesporites ancorae, and Densosporites fissus. None of the Rhaetian key-species (e.g. Rhaetipollis germanicus, Ovalipollis ovalis and Granuloperculatipollis rudis) were observed. Among the mainly Early Jurassic forms the species Perinopollenites elatoides, Quadraeculina anellaeformis and the genus Chasmatosporites were recorded. Pinuspollenites minimus was not recorded and the relative abundance of Corollina torosus did not reach beyond $3 \%$. The aquatic palynomorphs, totally dominated by acritarchs, comprise a very small part of all palynomorphs in this zone.

The considerable dissimilarity of the palynomorphassemblages in samples GA-1 and GA-3 (see the rangechart) should not be interpreted as a sudden change in the flora, but is probably a result of a change in the sedimentary environment. Sample GA-1 is from a thin, shaly interval in the sandstone covering the interval 1550 to $1535 \mathrm{~m}$ while sample GA-3 is from the uppermost Rhaetian marine, dark grey shale which continues into the Lower Jurassic Fjerritslev Formation.

\section{Zone B}

(GA-4 to GA-18) (1515 m to $1463 \mathrm{~m}$ ).

The base of this zone is defined partly by the appearance of abundant Pinuspollenites minimus and partly by a conspicuous increase in the relative abundance of Corollina torosus. The trilete spores constitute only $20-50 \%$ of the miospores in this zone. The saccate pollen dominate in the lower part of the zone and occur frequently in the upper part. Aperturate and alete pollen are also common. The zone is dominated by the miospore species Corollina torosus, Pinuspollenites minimus, Deltoidospora toralis, Perinopollenites elatoides and Calamospora tener. The species Quadraeculina anellaeformis, Cupressacites sp., Vitreisporites pallidus, Marattisporites scabratus, Cerebropollenites thiergartii, Monosulcites minimus and Aratrisporites minimus occur frequently. Of the mainly Rhaetic forms mentioned from Zone A, only Densosporites fissus was recorded (sporadically) from Zone B. A marked increase in abundance of aquatic palynomorphs $(20-40 \%$ of all palynomorphs), totally dominated by acritarchs, is seen in the lower part of the zone.

\section{Zone C}

(GA-19 to GA-60) (1454 m to $1209 \mathrm{~m}$ ).

The base of this zone is defined as the level where Cerebropollenites macroverrucosus appears together with Lycopodiumsporites semimuris. Lycopodiumsporites clavatoides appears higher in the zone. The upper limit of this zone coincides with a hiatus. In general there are relatively few trilete spores (about 10\% of the miospores). The zone is dominated by saccate, alete, and aperturate pollen. In Zone C, as in Zone B, the dominating miospore species are Corollina torosus, Pinuspollenites elatoides and Calamospora tener; Deltoidospora toralis is less abundant. In the upper part of the zone Spheripollenites psilatus occurs frequently. The relative abundance of aquatic palynomorphs ranges from 5 to $35 \%$ of all palynomorphs. Among those the acritarchs dominate totally. In the uppermost part of the zone the dinoflagellate-cysts show a rise in relative abundance and the Botryococcales also become more abundant. 


\section{Zone D}

(GA-65) (1177 $\mathrm{m}$ to $1170 \mathrm{~m})$.

This zone is restricted downwards by the hiatus. Six new species are present: Callialasporites microvelatus, Callialasporites segmentatus, Gleicheniidites conspiciendus, Gleicheniidites senonicus, Staplinisporites telatus and Manumia variverrucata. The zone is dominated by alete pollen ( $50 \%$ of all miospores), especially by the species Perinopollenites elatoides and Spheripollenites psilatus. Deltoidospora toralis and Monosulcites minimus are also relatively abundant while Corollina torosus and Pinuspollenites minimus show much lower relative abundances than in the preceeding zones. The aquatic palynomorphs, still dominated by acritarchs, constitute only about $13 \%$ of all palynomorphs. The dinoflagellate-cysts show an increase in diversity and the Botryococcales occur frequently.

\section{Zone E}

(GA-66 to GA-71) (1153 $\mathrm{m}$ to $1139 \mathrm{~m}$ ).

The base of this zone is defined as the level where the echinate Corollina-types (Corollina sp. 1 and Corollina sp. 2) appear. No definite upper boundary of this zone was recognized in the present study but could possibly be placed where the genus Cicatricosisporites becomes common. The aperturate and alete pollen dominate among the miospores. The dominant miospore species comprise Corollina torosus, Perinopollenites elatoides, Pinuspollenites minimus and Corollina sp. 1. There are about $30 \%$ aquatic palynomorphs, among which the

Figure 4. Location of palynological investigations used for correlation:

1) The Gassum No. 1-borehole (this study)

2) The Hobro No. 1-borehole (Bertelsen 1974)

3) Scania (several localities); the Rødby No. 1-borehole, Denmark; the Massbull No. 1-borehole, northwestern Germany; the Eitzendorf No. 8-borehole, northwestern Germany, south of Massbull (Lund 1977)

4) German Democratic Republic (Schulz 1967)

5) Middle- and southern England (Orbell 1973)

6) Northeastern France and Luxemburg (Schuurman 1977)

7) Jameson Land, East Greenland (Lund \& Pedersen 1985)

8) England and Scotland (Couper 1958)

9) Eastern Netherlands (Burger 1966).

The coastlines in the Early Jurassic are shown as dotted lines; arrows indicate the main directions of material transport from the land areas into the depositional basins (from Ziegler 1982).

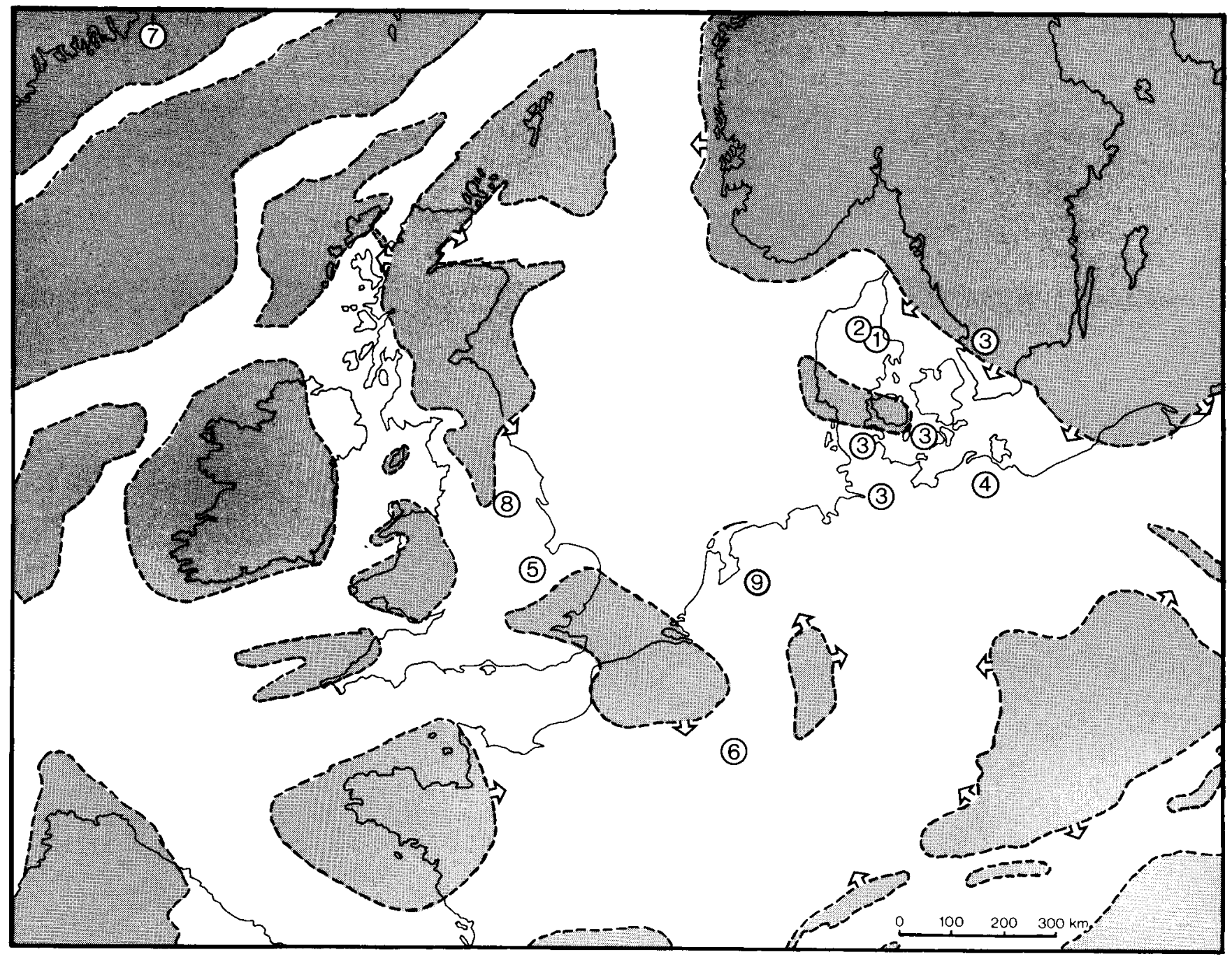


dinoflagellate-cysts are totally dominating. There are relatively few acritarchs while foraminiferal test-linings occur frequently.

\section{Age of the zones}

Figure 4 shows the location of the eight previously published palynological investigations used for the correlation and dating of Zones $\mathrm{A}$ to $\mathrm{E}$. Figure 5 presents the resulting biostratigraphic zonation of the relevant stratigraphic section from six of these investigations. Neither Couper (1958) nor Burger (1966) are mentioned in figure 5. Couper (1958) does not present a palynological zonation of the investigated strata, while Burger's (1966) investigation probably does not overlap this study stratigraphically. Figure 6 shows the stratigraphic range, according to the literature, of some of the stratigraphically most important miospores recorded in the present study.

\section{Zone A}

A Late Rhaetian age can reliably be assigned to this zone. The microflora, composed of both Rhaetic and Early Jurassic forms, corresponds very well with the "Oberrät microflora" defined by Schulz (1967) (= Zone 3 in figure 5). The "Oberrät microflora" is characterized by the common occurrence of, among others, Limbosporites lundbladii, Densosporites fissus, Cingulizonates rhaeticus, Heliosporites altmarkensis, Lycopodiacidites rugulatus, Ricciisporites tuberculatus, Quadraeculina anellaeformis, and species referred to the genus Chasmatosporites.

The microflora defining Zone A shows only a slight similarity to the Early and Middle Rhaetian microfloras presented by Orbell (1973) (the Rhaetipollis Zone), Bertelsen (1974) (Unit A and B), and by Schuurman (1977) (Phase 3). The microflora of Zone A comprises none of the key-species Rhaetipollis germanicus, Ovalipollis ovalis, Ovalipollis pseudoalatus, and Granuloperculatipollis rudis, and only shows a sparse occurrence of Ricciisporites tuberculatus.

The "Upper Rhaetic" (sensu germanico) microflora of the Ricciisporites-Polypodiisporites Zone proposed by Lund (1977) does not correspond to Zone A, being defined by the common occurrence of the species

Figure 5. Correlation of spore-pollen zones in northwestern Europe. Solid lines: confidently dated zone-boundaries. Dashed lines: less confidently dated zone-boundaries.

U.Z.w.C.m.: "Unnamed Zone with Cerebropollenites macroverrucosus"

P.T.Z.: The Pinuspollenites-Trachysporites Zone

R.P.Z.: The Ricciisporites-Polypodiisporites Zone

H.Z.: The Heliosporites Zone

R.Z.: The Rhaetipollis Zone.

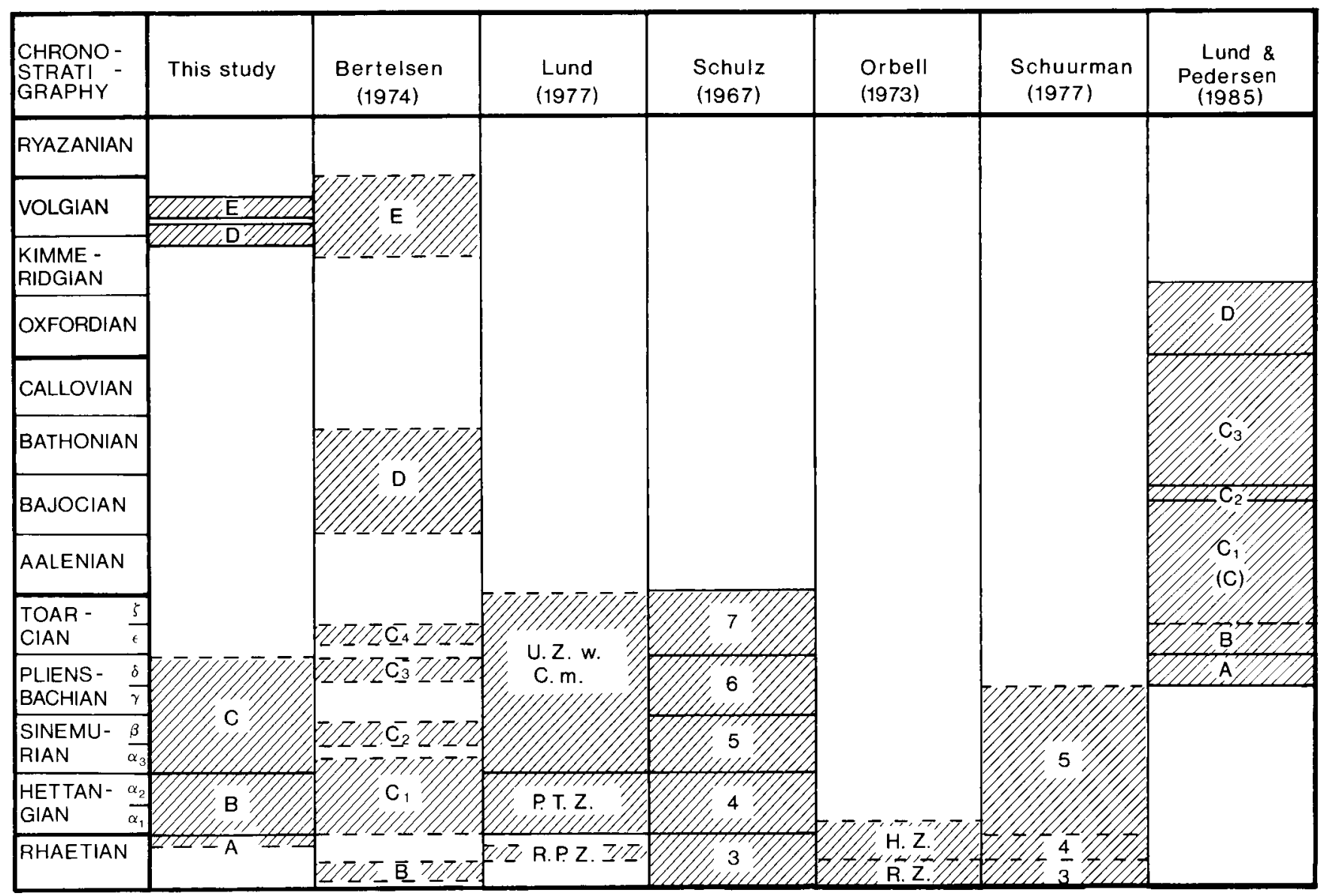




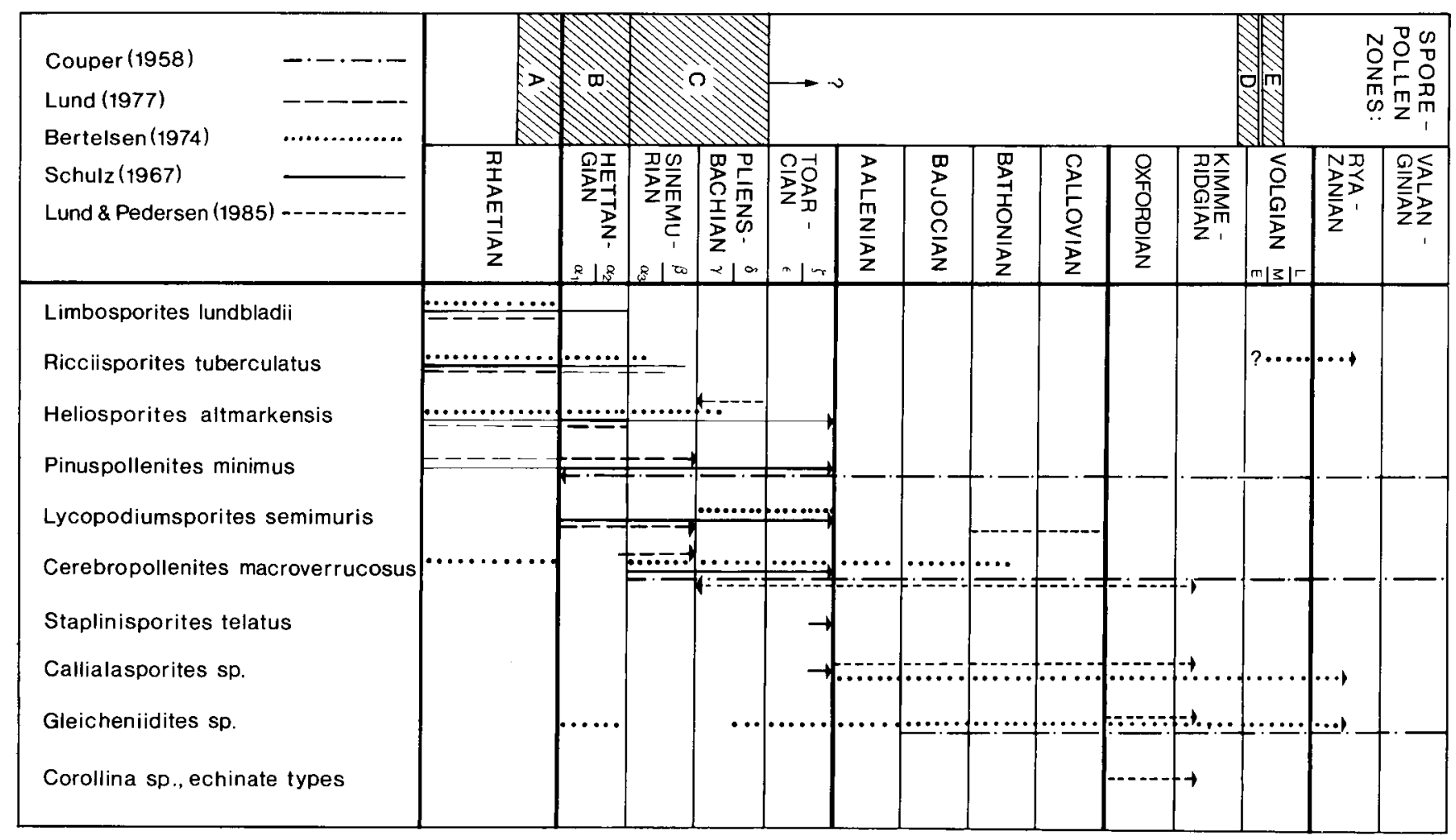

Polypodiisporites polymicroforatus (= Convolutispora microrugulatus) and of the genus Semiretisporis.

A rise in abundances of Deltoidospora and Baculatisporites, probably corresponding to the high relative abundances of the two genera in Zone A, was observed in the Rødby No. 1-borehole in an interval referred to "topmost Upper Rhaetic?" (Lund 1977). The mixed Rhaetian-Early Jurassic microflora recorded from this interval corresponds generally with the microflora in Zone A.

Based on comparisons with previously defined microflora-zones, Zone A is confidently considered to be younger than Middle Rhaetian and also younger than Lund's (1977) "Upper Rhaetic" (sensu germanico) Ricciisporites-Polypodiisporites Zone. At the same time the microflora of Zone A lacks the most important characteristics of Hettangian microfloras (see discussion of Zone B below).

\section{Zone B}

A Hettangian age can confidently be applied to this zone. An abrupt rise in the relative abundance of Pinuspollenites minimus, which defines the base of this zone, is observed at the Rhaetian-Hettangian boundary by both Schulz (1967) and Lund (1977).

The Hettangian microflora presented by Schulz (1967) (= Zone 4 in fig. 5) corresponds generally to the microflora of Zone B. Also Lund's (1977) Pinuspollenites-Trachysporites Zone, assigned a Hettangian age, corresponds to Zone $\mathrm{B}$, being characterized by the common occurrence of the genera Conbaculatisporites,
Figure 6. Stratigraphic ranges, according to the literature, of the stratigraphically important spore-pollen species recorded in the present study. The arrows show limits of the specific investigation and thus do not indicate the first-or last appearance of the species.

Trachysporites and Uvaesporites, with Rhaetic forms like Limbosporites lundbladii and Densosporites fissus being absent or occurring sporadically.

In addition, the microflora of the $\mathrm{C}_{1}$-subzone defined by Bertelsen (1974) and assigned a Hettangian-Early Sinemurian age, corresponds very well to Zone B as defined in the present study. Bertelsen's Subzone $C_{1}$ is dominated by the species Perinopollenites elatoides, Corollina torosus, and by specimens referred to the genus Deltoidospora. Ricciisporites tuberculatus occurs sporadically but many other Rhaetic forms have disappeared. Cerebropollenites thiergartii appears within Subzone $\mathrm{C}_{1}$ of Bertelsen.

The upper boundary of Zone B is defined by the appearance of Cerebropollenites macroverrucosus at the Hettangian-Sinemurian boundary (see discussion of Zone $\mathrm{C}$ below).

\section{Zone C}

The base of this zone can confidently be assigned to the Hettangian-Sinemurian boundary. The age of the upper boundary (at the start of the hiatus) is more uncertain, but is probably close to the PliensbachianToarcian boundary. 
The species Cerebropollenites macroverrucosus, defining the base of Zone $\mathrm{C}$ has, according to Schulz (1967), its first occurrence at the Hettangian-Sinemurian boundary in East Germany. According to Lund (1977) it appears in the uppermost Hettangian to the lowermost Sinemurian in the Rødby No. 1-borehole, the Eitzendorf No. 8-borehole, and in Scania. The appearance of this species defines the base of Lund's (1977) "Unnamed Zone with Cerebropollenites macroverrucosus". Apart from this species his zone is characterized by the common occurrence of specimens referred to the genus Lycopodiumsporites (including $L y$ copodiumsporites semimuris) and corresponds generally to Zone C. Phase 5 of Schuurman (1977) corresponds very well to Zone $\mathrm{C}$, being characterized by the dominance of specimens referred to the genus Corollina and smooth, trilete spores together with $\mathrm{He}$ liosporites reissingeri, Lycopodiumsporites semimuris, Stereisporites cicatricosus, Cerebropollenites macroverrucosus, and Zebrasporites interscriptus. This phase is assigned a Hettangian to Early Pliensbachian age.

The total dominance of Ricciisporites tuberculatus in sample GA-53 seems strange. In NW-Europe $R$. tuberculatus ranges from Norian to Sinemurian with its acme in the Rhaetian (Schulz 1967, Lund 1977, Pedersen \& Lund 1980). In the present study this species was only recorded in two samples, in GA-3 (1536 m b.r.t.) and in GA-53 (1277 m b.r.t.). According to Sorgenfrei \& Buch (1964) the level $1536 \mathrm{~m}$ b.r.t. belongs to uppermost Rhaetian, while the level $1277 \mathrm{~m}$ b.r.t. is referred to Late Pliensbachian. In GA-53 R. tuberculatus constitutes about $35 \%$ of the recorded spores and pollen and is clearly the dominant palynomorph. As the species was not recorded in the interval between these two levels and as it normally does not occur above Sinemurian, the pollen-grains in GA-53 are presumed to have been reworked from older sediments.

None of the genera Callialasporites, Gleicheniidites, Staplinisporites and Manumia, which have their first appearance in the uppermost Early Jurassic and Middle Jurassic, were recorded in Zone C.

A sudden dominance of Nannoceratopsis gracilis was recorded in sample GA-60 (only a few specimens had been recorded from samples below). This sudden dominance may indicate an age near the PliensbachianToarcian boundary (Morbey 1978).

\section{Zone D}

This zone, comprising only one sample, cannot, on the basis of miospores alone, be assigned an age more accurate than between Late Toarcian and Kimmeridgian.

The stratigraphically most important miospore taxa recorded in this zone are Callialasporites, Gleicheniidites, Staplinisporites telatus, and Manumia variverrucata.
The genus Callialasporites appears in Late Toarcian in East Germany (Schulz 1967). In the Hobro No. 1-borehole it was recorded from the Middle Jurassic (Bertelsen 1974) and in Jameson Land, East Greenland, it was recorded from the Bajocian (Lund \& Pedersen 1985).

The genus Gleicheniidites was recorded from the Bajocian in Great Britain (Couper 1958), the Hettangian-Sinemurian in the Hobro No. 1-borehole (Bertelsen 1974), and the Oxfordian in Jameson Land, East Greenland (Lund \& Pedersen 1985).

The zone D defined by Lund \& Pedersen (1985) and assigned an Oxfordian-Kimmeridgian age, is characterized by the appearance of the genus Gleicheniidites, especially the species Gleicheniidites conspiciendus, which is also recorded from the Zone D of the present study.

The species Staplinisporites telatus was recorded from Late Toarcian in East Germany (Schulz 1967). The genus Manumia was recorded from Toarcian in Jameson Land, East Greenland (Lund \& Pedersen 1985), and the species Manumia variverrucata has its first occurrence in Early Toarcian in DDR and the eastern Netherlands (Schulz 1967, Herngren \& de Boer 1974).

No echinate Corollina-types were recorded from Zone D (see discussion of Zone $\mathrm{E}$ below).

\section{Zone E}

This zone can be assigned an age from Oxfordian to the latest Jurassic. A more accurate dating is not possible on the basis of miospores alone.

The base of Zone $\mathrm{E}$ is defined as the level where echinate Corollina-types appear. Those are recorded from the Oxfordian in Jameson Land, East Greenland (Lund \& Pedersen 1985) and from the uppermost Late Jurassic ("higher Upper Malm") in the eastern Netherlands (Burger 1966).

In the Hobro No. 1-borehole and in the eastern Netherlands specimens referred to the genus Cicatricosisporites were recorded in large numbers from the uppermost Late Jurassic (Burger 1966, Bertelsen 1974). A single specimen referred to this genus was recorded from sample GA-71, the topmost sample of Zone E.

\section{Age of the zones $D$ and $E$ based on dinoflagellate-cysts}

In addition to the spores and pollen, the samples from the zones $\mathrm{D}$ and $\mathrm{E}$ contain a diverse and well-preserved dinoflagellate-cyst assemblage. The recorded dinoflagellate-cysts permitt a more detailed stratigraphical correlation of the two zones. Identification and correla- 


\begin{tabular}{|c|c|c|c|}
\hline SPORE / POLLEN ZONES & 마 & & \\
\hline SAMPLE NUMBERS (GA-) & & & 597 \\
\hline 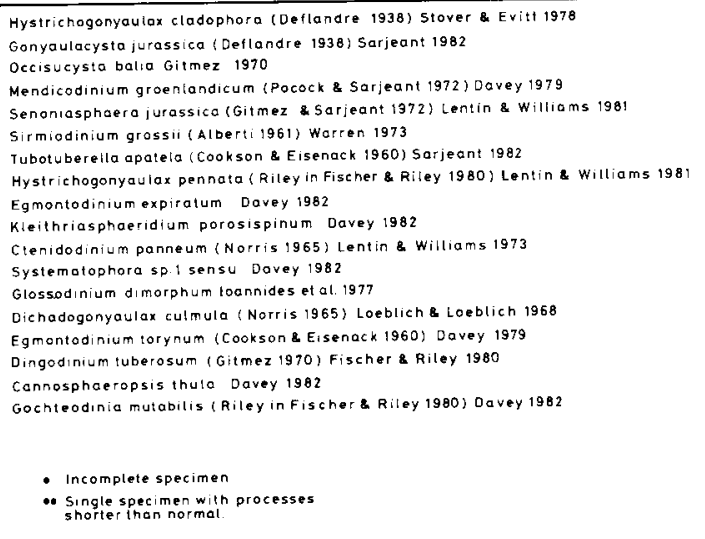 & $\mid \begin{array}{l}? \\
x \\
x \\
x \\
x\end{array}$ & $\begin{array}{l}x \\
x \\
x \\
x \\
x \\
x \\
x \\
x \\
x \\
x \\
x \\
?^{\infty} \\
\end{array}$ & 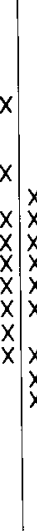 \\
\hline
\end{tabular}

Figure 7. Dinoflagellate-cyst species recorded from the four top-most samples counted (in the spore-pollen zones $D$ and E). The specimens were identified by C. Heilmann-Clausen, Geological Institute, University of Aarhus.

tion of the dinoflagellate-cysts was carried out by Claus Heilmann-Clausen, Geological Institute, University of Aarhus. The recorded dinoflagellate-cysts species are shown in figure 7 ; figure 8 shows the stratigraphically most important ones and their ranges according to the litterature.

\section{Zone D}

A Kimmeridgian - Early Volgian age can be confidently assigned on the presence of Gonyaulacysta jurassica, Occisucysta balia and Senoniasphaera jurassica. The presence of a doubtful Hystrichogonyaulax cladophora and the absence of Ctenidodinium panneum suggests a Kimmeridgian (pre-Volgian) age.

\section{Zone E}

A Middle Volgian age, no younger than the Anguiformis ammonite Zone, can be reliably applied, but the exact age within the Middle Volgian is uncertain. The presence of Egmontodinium expiratum in sample GA-67 points to an age for this sample no older than the Kerberus ammonite Zone. On the other hand, Senoniasphaera jurassica in samples GA-67 and GA-69 is not considered to range above the Albani ammonite Zone.

The presence of Dichadogonyaulax culmula (frequent) and Glossodinium dimorphum in sample GA-71 is a reliable indication of an age no younger than the Anguiformis ammonite Zone. The absence of Senoniasphaera jurassica and presence of Cannosphaeropsis thula (frequent) probably indicates an age within the Kerberus-Anguiformis ammonite Zones.

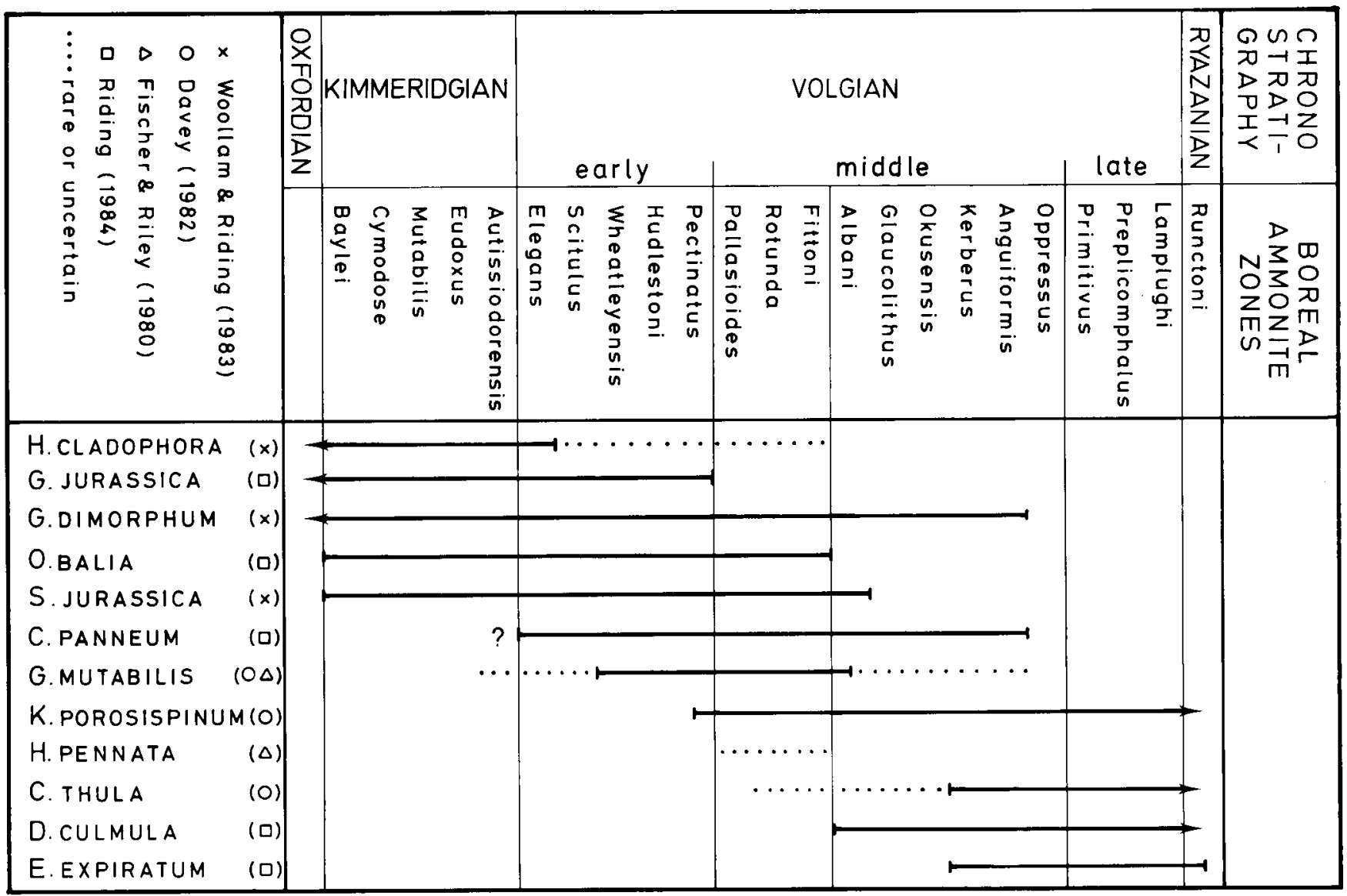

Figure 8. Ranges, according to the literature, of the stratigraphically most important dinoflagellate-cysts species recorded from the four top-most samples counted (in the spore-pollen zones $D$ and $E$ ) in the present study. The references from which the stated ranges have been obtained are indicated. 


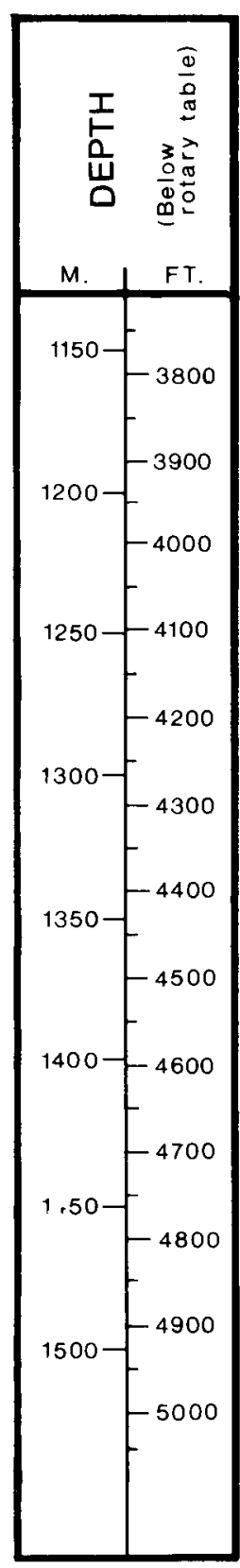

\section{Stratigraphical conclusion}

Correlation with previous palynological investigations in Northwest Europe allows the five zones, A to E, of the present study, to be dated as follows:

\section{Zone E:}

(GA-66 to GA-71)

(1153 $\mathrm{m}$ to $1139 \mathrm{~m})$

Zone D:

(GA-65)

(1177 $\mathrm{m}$ to $1170 \mathrm{~m}$ )

Zone $C$ :

(GA-19 to GA-60)

(1454 m to $1209 \mathrm{~m}$ )

gian

Early Sinemurian to

?Pliensbachian/Toarcian
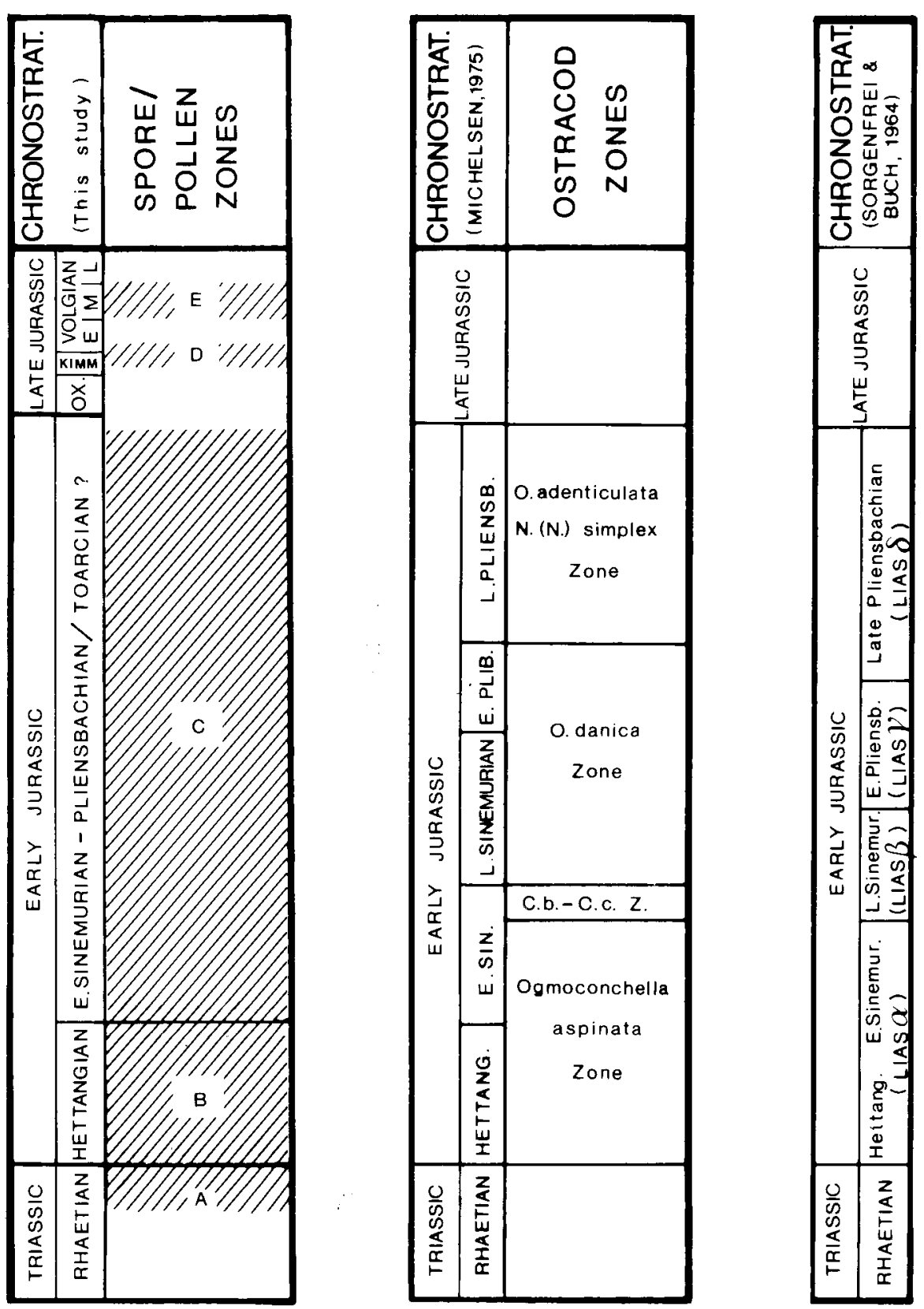

Figure 9. Correlation of biozonations and chronostratigraphy of the Lower Jurassic section in the Gassum No. 1-borehole. C.b.-C.c.Z.: C. betzi-C. crassireticulata Zone.

Zone B:

Hettangian

(GA-4 to GA-18)

$(1515 \mathrm{~m}$ to $1463 \mathrm{~m})$

Zone $A$ :

Late Rhaetian

(GA-1 to GA-3)

(1538 $\mathrm{m}$ to $1533 \mathrm{~m}$ )

This stratigraphical conclusion corresponds well with the bio- and chronostratigraphical subdivisions of the Gassum borehole by Sorgenfrei \& Buch (1964) and Michelsen (1975) (see fig. 9). 


\section{Palaeoenvironment}

The recording of frequent marine palynomorphs in all counted samples reveals that the depositional environment was marine throughout the studied section in the Gassum No. 1-borehole.

Further information concerning the depositional environment can be obtained by dividing the palynomorphs into specific groups and study variations in the relative abundances of these groups. This has been done by Pedersen \& Lund (1980, figs. 11 and 12) and Lund \& Pedersen (1985, fig. 7). They divided the terrestrial palynomorphs (the miospores) into five main morphological groups: trilete spores, monolete spores, saccate pollen, alete pollen, and aperturate pollen. The relative occurrence of these groups through the studied section was used to interpret the palaeoenvironment. According to Lund \& Pedersen (1985) the group of trilete spores comprises relatively heavy, mainly watertransported palynomorphs. The frequency of this group is therefore possibly inversely proportional to the distance from rivermouths and shorelines. Conversely, a relative maximum of saccate pollen indicates a greater distance from the shore.

A corresponding grouping of the palynomorphs recorded in the present study is shown in figure 10. The first part of the figure (part I) shows the relationship between the terrestrial palynomorphs (the miospores and Botryococcales) and the marine palynomorphs. These variations are presumed to be related to changes in sea-level (see also p. 38). Part II of the figure shows the relative mutual abundance of the five main morphological groups of terrestrial palynomorphs, and part III shows the relative mutual abundance of the five aquatic groups: Dinoflagellate-cysts, Acritarchs, Tasmanitids, Botryococcales and Foraminiferal test-linings.

Botryococcus is a freshwater to brackish colonial algae. Thus a large relative abundance of these indicates an influence of fresh to brackish water. The remaining four groups together constitute the marine palynomorphs (see part I, fig. 10).

In general the variation in the relative abundance of marine palynomorphs in relation to the terrestrial palynomorphs, and the relative abundance of saccate pollen, correspond very well. As expected, the curve showing the relative abundance of trilete spores shows a reverse tendency. Thus a coincident minimum of trilete spores and a maximum of saccate pollen and marine palynomorphs indicate a fully marine environ- ment, while the opposite pattern indicates a more marginal, fluvially-influenced depositional environment.

Based on these assumptions the maximum marine conditions occurred in the following intervals: 1) uppermost Rhaetian to lowermost Hettangian, 2) Lower Sinemurian, 3) $1402 \mathrm{~m}$ to $1341 \mathrm{~m}$ (Upper Sinemurian according to Sorgenfrei \& Buch, 1964), 4) $1341 \mathrm{~m}$ to $1280 \mathrm{~m}$ (Lower to Upper Pliensbachian according to Sorgenfrei \& Buch, 1964) (see also p. 38).

The sudden maximum of dinoflagellate-cysts in sample GA-36 at $1372 \mathrm{~m}$ is due to the abundance of only one species Liasidium variabile and not a normal, diverse marine assemblage. This maxima probably indicates a restricted environment, inducing a bloom of $L$. variabile, rather than a fully marine environment.

Two remarkable maxima occur in sample GA-53: one in the aperturate pollen due to the sudden abundance of Ricciisporites tuberculatus, and one shown by the Botryococcales. Marine palynomorphs are less abundant at this level. The sudden appearance of abun-

Figure 10. The relative abundances of the main morphological groups.

Part 1: The relationship between terrestrial and marine palynomorphs. The limnic algae-genus Botryococcus is included in the terrestrial palynomorphs together with the spores and pollen. The four remaining groups of aquatic palynomorphs together constitute the marine palynomorphs $(100 \%=$ all recorded palynomorphs).

Part II: Distribution of the five main morphological groups of spores and pollen $(100 \%=$ total of spores + pollen $)$.

a) The trilete spores. The innermost curve indicates laevigate (unsculptured) trilete spores while the outermost curve indicates the sculptured trilete spores

b) The monolete spores

c) The saccate pollen

d) The alete pollen. The innermost curve shows the genus Spheripollenites

e) The aperturate pollen (monocolpate, praecolpate and monoporate). The innermost curve shows the genus Corollina.

Part III: Distribution of aquatic palynomorphs, divided into the following groups $(100 \%=$ total of aquatic palynomorphs):

a) The dinoflagellate-cysts

b) The acritarchs

c) The tasmanitids

d) The botryococcales

e) The foraminiferal test-linings. 

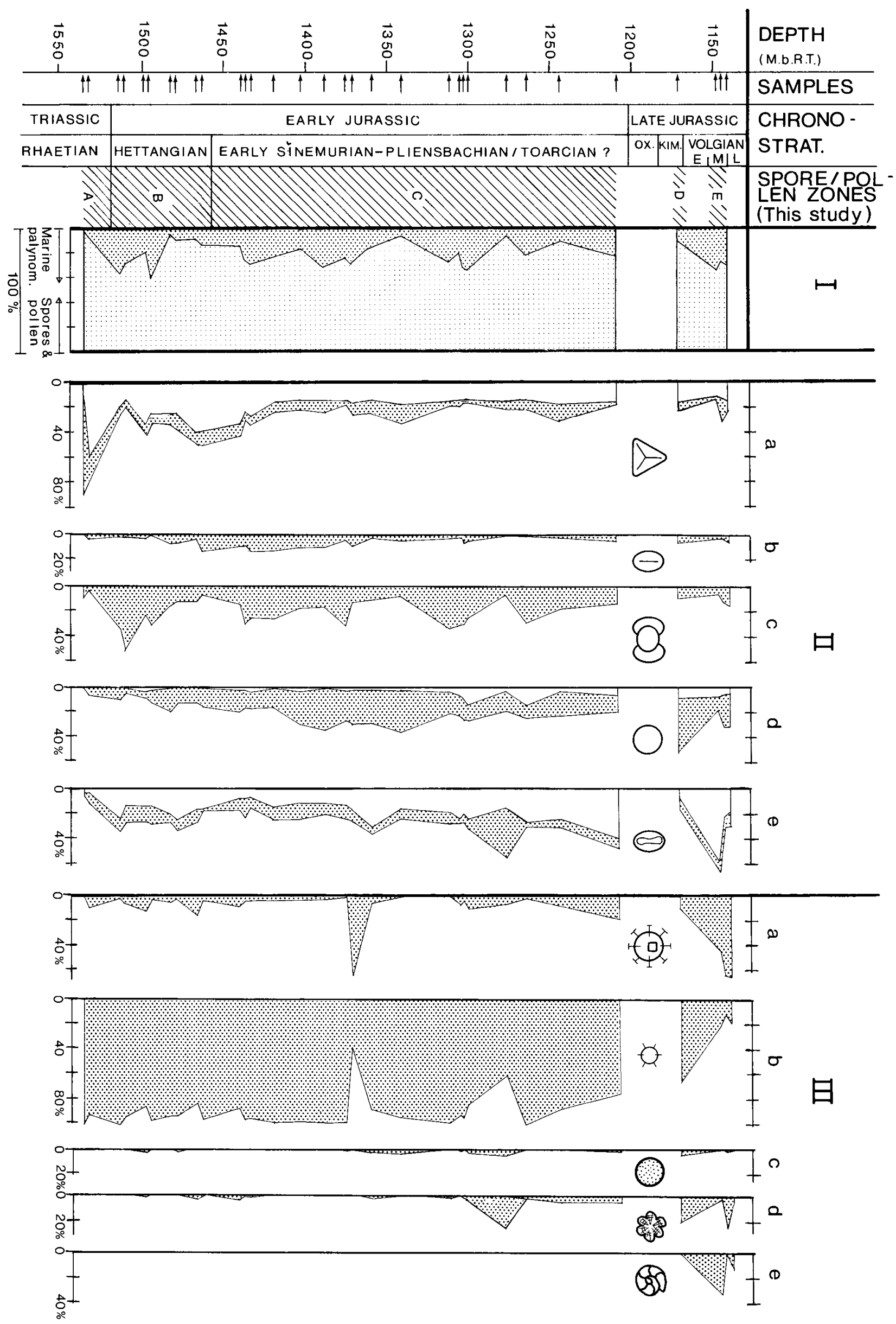
dant $R$. tuberculatus possibly indicates a short-spanned regressive phase resulting in erosion and reworking of older sediments (see p. 33). The coincident increased recovery of Botryococcales also points towards a regressive phase with greater influence from fluviatile systems.

A remarkable maximum of the genus Spheripollenites was recorded by Lund \& Pedersen (1985) in Jameson Land, East Greenland, in their assemblage B, referred to Early Toarcian. A contemporary maximum of Spheripollenites was observed by Morbey (1978) in northwestern Europe and was supposed to be climatically controlled. The recorded maximum coincided with a maximum of Corollina and a minimum of bisaccate pollen. In the present study Spheripollenites has low occurrence up to about $1310 \mathrm{~m}$ where there is a rise in the relative abundance from about 1 to about $14 \%$; above this level the abundance varies between $1 \%$ and $13 \%$. The increase in Spheripollenites is contemporary with a weak, gradual rise in the abundance of Corollina (fig. 10, part II, e), and a weak fall in the abundance of saccate pollen. According to Sorgenfrei \& Buch (1964) the level where these tendencies start should be of Late Pliensbachian age. This agrees generally with the observations of Morbey (1978) and Lund \& Pedersen (1985).

\section{Eustatic sea-level changes reflected in the distribution of palynomorphs}

The Early Jurassic Transgression recognized in northwestern Europe consisted of successive phases of sealevel rises interrupted by minor shallowing events (Hallam 1978, 1981; Vail \& Todd 1981). According to Hallam (1981) the most important of these transgression phases, recognized through sedimentological and palaeontological investigations, occurred in the following periods: earliest Hettangian, Early Sinemurian, Late Sinemurian to Early Pliensbachian, Late Pliensbachian, and Early Toarcian (see figure 11).

Subsidence in the Danish Subbasin during the Early Jurassic was probably fault-controlled, but it is still possible to recognize the five regional, eustatic phases of sea-level rise in the sedimentary sequences along the margin of the Danish Subbasin, and as weaker lithological changes in the central parts of the basin (Bertelsen 1978, Michelsen 1978, Pedersen 1986). In addition to the five regional phases, there is evidence for Mid- to Late Sinemurian deepening events in the Danish Subbasin (Pedersen 1986).

As the phases of transgression are lithologically recognizable they must also be expected to have influenced the distribution of micro- and macrofossils. According to Hallam (1976) the initial phases of smaller transgressions favour development of anoxic conditions and thus influence the composition of the bivalve fauna.

Pedersen (1986), who studied the bivalve fauna in the Lower Jurassic section of the Gassum No. 1-borehole, divided the fauna into five feeding groups and compared their mutual variations with the phases of sea-level rise. She concluded that the phases of sealevel rise in the earliest Hettangian, the Early Sinemurian and the Late Pliensbachian had no significant effect on the composition of the bivalve fauna, while the Late Sinemurian - Early Pliensbachian deepening event was clearly reflected by a distinct change in the faunal composition, probably caused by a decrease in the oxygencontent of the bottom-water. A further drop in the oxygen-content at the Early Toarcian deepening event probably caused the disappearance of bivalves in the uppermost core of Late Pliensbachian age.

The relationship between marine and terrestrial palynomorphs in the present study is shown in figure 10, part $I$. The same curve is shown in figure 11 where it is vertically compressed to allow correlation with Hallam's (1981) curve of eustatic sea-level changes in the Early Jurassic. His five major phases of sea-level rise are marked by an asterisk.

Comparison of the two curves in figure 11 shows:

The basal Hettangian phase of sea-level rise coincides with a distinct maximum of marine palynomorphs.

The phase of sea-level rise in Early Sinemurian also coincides with a maximum of marine palynomorphs, although it is not as distinct as the preceding one.

A third maximum of marine palynomorphs occurs in the middle of Sinemurian. This maximum does not correlate with any of Hallam's phases of sea-level rise, but supports evidence for Mid- to Late Sinemurian deepening events in the Danish Basin presented by Pedersen (1986, fig. 7).

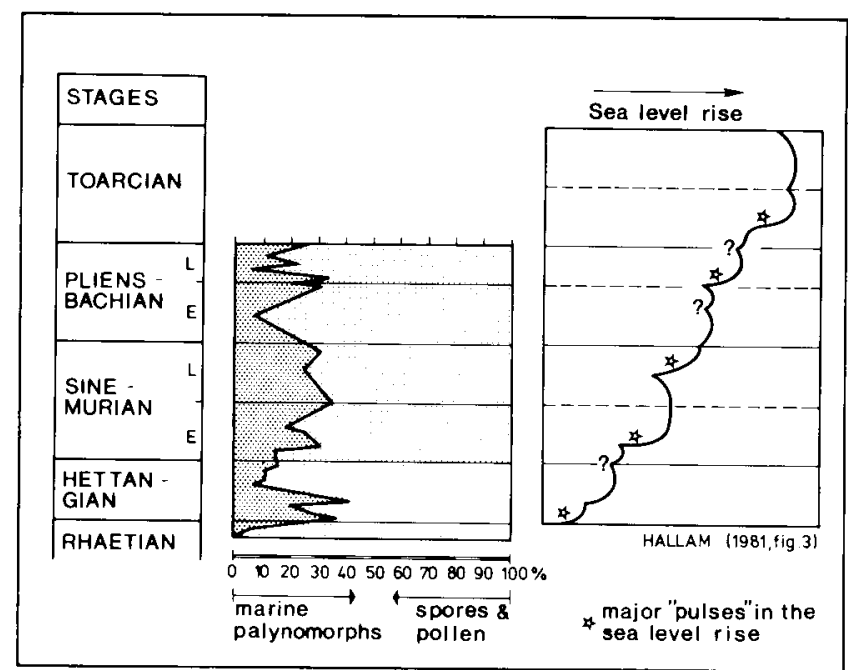

Figure 11. The relationship between marine- and terrestrial palynomorphs, correlated with Hallam's (1981) curve of Early Jurassic eustatic sea-level changes. 
The Late Sinemurian to Early Pliensbachian phase of sea-level rise is contemporary with a maximum of marine palynomorphs, although it is partly masked by the maximum in the middle of the Sinemurian.

Finally, the Late Pliensbachian phase of sea-level rise coincides with a distinct maximum of marine palynomorphs. There is a weak tendency towards a rise in the marine palynomorphs in the samples just below the hiatus, which could reflect initiation of the Early Toarcian rise in sea-level.
It seems that the levels showing maximal relative abundances of marine palynomorphs correlate rather well with the phases of sea-level rise presented by Hallam (1981) and sedimentologically recorded in the Danish Subbasin. Nevertheless, these results have to be used with some reservation as the lack of an ammonite-zonation of the Gassum No. 1-borehole prevents detailed stratigraphical correlation. 


\section{Acknowledgements}

The author wishes to thank the Carlsberg Foundation for financial support in the form of a Scholar Stipendium. The Geological Survey of Denmark kindly made the material available.

Many people have provided valuable help during the investigation and the preparation of the manuscript and they are all gratefully thanked here, especially $\mathrm{Kaj}$ Raunsgaard Pedersen, Bitten Larsen, Else Marie Friis, Claus Heilmann-Clausen, Henrik Friis, Marianne Vasard Nielsen, Gunver Krarup Pedersen, Lissie Jans, Lis Sinnerup Olesen, Peter Crane, Richard Wilson and Richard Tyson.

\section{References}

Alberti, 1961: Zur Kenntnis mesozoischer und alttertiärer Dinoflagellaten und Hysterichosphaerideen von Nord- und Mitteldeutschland, sowie einigen anderen europäischen Gebieten. Palaeontographica, Abt. A 116, 1-58.

Balme, B.E., 1957: Spores and pollen grains from the Mesozoic of Western Australia. Coal Res. C.S.I.R.O. Ref. T.C. 25, 1-48.

Bertelsen, F., 1974: Palynological investigations of the Triassic-Jurassic section of the Hobro No. 1 borehole. In: Michelsen, O., 1979: Report on the Jurassic of the Hobro No. 1 and Voldum No. 1 borings, Denmark. Danm. geol. Unders. Årbog 1978, 141-149.

Bertelsen, F., 1978: The Upper Triassic-Lower Jurassic Vinding and Gassum Formations of the Norwegian-Danish Basin. Danm. geol. Unders., Ser. B, 3. 26 pp.

Bharadwaj, D.C. \& Singh, H.P., 1964: An Upper Triassic Miospore Assemblage from the Coals of Lunz, Austria. Palaeobotanist 12 (1)., 28-44.

Bolchovitina, N.A., 1953: Charactères sporo-polleniques du Crétacé de la partie centrale de I'SSSR. Akad. Nauk. S.S.S.R. Tr. Geol. Inst. 145(61), 1-184 (in russian).

Brenner, G.J., 1963: The spores and pollen of the potomac Group of Maryland. Dept. Geol., Mines and Water Res., State of Maryland, Bull. 27, 1-215.

Burger, D., 1965: Some new species of Classopollis from the Jurassic of the Netherlands. Leid. geol. Mededel. 33, 63-69.

Burger, D. 1966: Palynology of Uppermost Jurassic and Lowermost Cretaceous strata in the Eastern Netherlands. Leid. geol. Mededel. $35,208-276$.

Cookson, I.C., 1947: Plant Microfossils from the Lignites of Kergue len Archipelago. B.A.N.Z. Antarc. Res. Exped. 1929-1931, Rep. Ser. A. 2(8), 127-142.

Cookson, I.C., 1953: Difference in microspore composition of some samples from a bore at Comaum, South Australia. Aust. Jour. Bot., 1(3), 462-473.

Cornet, B. \& Traverse, A., 1975: Palynological contributions to the chronology and stratigraphy of the Hartford Basin in Connecticut and Massachusetts. Geoscience and Man 11, 1-33.

Couper, R.A., 1953: Upper Mesozoic and Cainozoic spores and pollen grains from New Zealand. New Zealand Geol. Surv., Paleontological Bull. 22, 1-77.

Couper, R.A., 1958: British Mesozoic microspores and pollen grains. A systematic and stratigraphic study. Palaeontographica, Abt. B 103(4-6), 75-179.

Danzé-Corsin, P. \& Laveine, J.P., 1963: In: Briche, P., DanzéCorsin, P. \& Laveine, J.P.: Flore infraliassique du Boullonnais (Macro-et Microflore). Mém. Soc. Géol. Nord. 13, 57-109.

Davey, R.J., 1979: The stratigraphic distribution in the Portlandian (latest Jurassic) to Barremian (Early Cretaceous) of northwest Europe. American Association of Stratigraphic Palynologists, Contribution Series 5B, 48-81.

Davey, R.J., 1982: Dinocyst stratigraphy of the latest Jurassic to Early Cretaceous of the Haldager No. 1 borehole, Denmark. Geol. Surv. Denmark, Ser. B, 6.57 pp.

Deegan, C.E. \& Scull, B.J., 1977: A standard lithostratigraphic nomenclature for the Central and Northern North Sea. Inst. Geol. Sci., Oljedirektoratet, Rep. 77/25, Bull. 1. 36 pp.

Deflandre, G., 1937: Microfossiles de silex crétacés II. Flagellés incertae sedis. Hystrichosphaeridées. Sarcodinés. Organismes divers. Annls. Paléont. 26, 51-103.

Dettmann, M.E., 1963: Upper Mesozoic microfloras from SouthEastern Australia. Proc. Roy. Soc. Victoria., New Ser. 77 (1), $1-148$.

Deunff, J., 1954: Veryhachium, genre nouveau d'Hystrichosphéres du Primaire. C.R.S. Soc. Géol. France 13, 305-307. 
Dev, S., 1961: The fossil flora of the Jabalpur Series - 3. Spores and pollen grains. Palaeobotanist 8(1-2), 43-56.

Downie, C., Evitt, W.R. \& Sarjeant, W.A.S., 1963: Dinoflagellates, hystrichospheres and the classification of the acritarchs. Stanford Univ. Publ. Geol. Sci. 7(3), 1-16.

Downie, C. \& Sarjeant, W.A.S., 1963: On the interpretation and status of some hystrichosphere genera. Palaeontology 6(1), 83-96.

Drugg, W.S., 1978: Some Jurassic dinoflagellate cysts from England, France and Germany. Palaeontographica, Abt. B 168(1-3), 61-79.

Döring, H., 1965: Dic sporenpaläeontologische Gliederung des Wealden in Westmecklenburg (Struktur Werle). Geologie, Berlin 14(47), 1-118.

Döring, H., Krutzsch, W., Mai, D.H. \& Schulz, E., 1963: Retitriletes. In: Krutzsch, W., 1963: Atlas der mittel- und jungtertiären dispersen Sporen- und Pollen- sowie der Mikroplanktonformen des nördlichen Mitteleuropas. Lief. II VEB Deutscher Verlag der Wissenschaften, Berlin, 8-18.

Döring, H., Krutzsch, W., Schulz, E. \& Timmermann, E., 1966: Über einige neue Subformgenera der Sporengattung Stereisporites TH. und PF. aus dem Mesozoikum und Alttertiär Mitteleuropas. Geologie, Berlin 15(55), 72-89

Eisenack, A., 1958: Tasmanites Newton und Leiosphaeridia n.g. als Gattungen der Hystrichosphaeridea. Palaeontographica, Abt. A $110,1-19$.

Erdtman, G., 1948: Did Dicotyledonous Plants Exist in Early Jurassic Times? Geol. Fören. Stockh. Förh. 70, 265-271.

Evitt, W.R., 1961: Dapcodinium priscum n. gen., n. sp., a Dinoflagellate from the Lower Lias of Denmark. Jour. of Palaeont. 35(5), 996-1002.

Evitt, W.R., 1962: Dinoflagellate synonyms: Nannoceratopsis de flandrei Evitt junior to N?. gracilis Alberti. Jour. Palaeont. 36, 1129-1130.

Filatoff, J., 1975: Jurassic Palynology of the Perth Basin, Western Australia. Palaeontographica, Abt. B 154(1-4), 1-113.

Fischer, M.J. \& Riley, L.A., 1980: The stratigraphic distribution of dinoflagellate cysts at the boreal Jurassic-Cretaceous boundary. IV Int. Palynol. Conf. Lucknow (1976-77), 2, 313-329.

Frebold, H., 1948: The Stratigrapical Subdivision of the Lower Cretaceous and the Jurassic in Gassum Well No. 1. (Based on Megafossils). DapCo (unpublished report). $7 \mathrm{pp}$

Gitmez, G.U., 1970: Dinoflagellate cysts and acritarchs from the basal Kimmeridgian (Upper Jurassic) of England, Scotland and France. Bull. British Museum (Nat. Hist.) Geol., 18, 231-331.

Grebe, H., 1971: A recommended terminology and descriptive method for spores. Publ. Comm. Internat. de Microflore du Paleozoique $4,11-34$.

Gregersen, A. \& Sorgenfrei, T., 1951: Efterforskningsarbejdet i Danmarks dybere undergrund. Meddr. dansk geol. Foren. 12, 141

Groot, J.J. \& Penny, J.S., 1960: Plant microfossils and age of nonmarine Cretaceous sediments of Maryland and Delaware. Micropaleontology 6(2), 225-237.

Hallam, A., 1976: Stratigraphic distribution and ecology of europian Jurassic bivalves. Lethia 9, 245-259.

Hallam, A., 1978: Eustatic cycles in the Jurassic. Palaeogeogr Palaeoclimatol. Palaeoecol. 23, 1-32.

Hallam, A., 1981: A revised sea-level curve for the early Jurassic. J geol. Soc. London 138(6), 735-743.

Harland, R., Morbey, S.J. \& Sarjeant, W.A.S., 1975: A revision of the Triassic to lowest Jurassic dinoflagellate Rhaetogonyaulax. Palaeontology 18(4), 847-864.

Herngren, G.F.W. \& Boer, K.F. de, 1974: Palynology of Rhaetian, Liassic and Dogger strata in eastern Netherlands. Geol. en Mijnbouw 53(6), 343-368.

Hoelstad T. 1985: Palynology of the uppermost Lower to Middle Jurassic strata on Bornholm, Denmark. Bull. geol. Soc. Denmark $34,111-132$

Horst, U., 1943: Mikrostratigraphischer Beitrag zum Vergleich des Namur von West-Oberschlesien und Märisch-Ostrau. Die Megaund Mikrosporen der hauptsächlichen Flöze beider Reviere. Diss. Techn. Hochsch. Berlin.

Hughes, N.F., 1961: Further interpretation of Eucommiidites Erdtman 1948. Palaeontology 4(2), 292-299.

Ibrahim, A., 1933: Sporenformen des Aegierhorizontes des Ruhrreviers. Diss. Techn. Hochsch. Berlin, Würzburg, 1-47.
Ioannides, N.S., Stavrinos, G.N. \& Downie, C., 1977: Kimmeridgian microplankton from Clavel's Hard, Dorset, England. Micropalaeontology $22,443-478$.

Kedves, M. \& Simoncsics, P., 1964: Microstratigraphy of the carbonate manganese ore layers of the shaft III of Urkút on the basis of palynological investigations. Acta Min. Pet. 16 (2), 3-48.

Kemp, E., 1970: Aptian and Albian miospores from southern England. Palaeontographica, Abt. B 131(1-4), 73-143.

Klaus, W., 1960: Sporen der kernischen Stuffe der ostalpinen Trias. Jahrb. Cicol. Bundesanst., Sonderb. 5, 107-183.

Krutzsch, W., 1959: Mikropaläontologische (sporenpaläontologische) Untersuchungen in der Braunkohle des Geiseltales. Geologie, Berlin 8(21-22). 425 pp.

Krutzsch, W., 1963: Atlas der mittel- und jungtertiären dispersen Sporen- und Pollen- sowie der Mikroplanktonformen des Nördlichen Mitteleuropas. Lief. II, III. VEB Deutscher Verlag der Wissenschaften, Berlin. $141 \mathrm{pp} ; 128 \mathrm{pp}$.

Krutzsch, W., 1967: Atlas der mittel- und jungtertiären dispersen Sporen- und Pollen- sowie der Mikroplanktonformen des Nördlichen Mitteleuropas. Lief. IV/V. VEB Deutscher Verlag der Wissenschaften, Berlin. 232 pp.

Larsen, G., 1966: Rhaetic-Jurassic-Lower Cretaceous Sediments in the Danish Embayment. (A Heavy-Mineral Study). Danm. geol. Unders. II Rakke 91. 127 pp.

Lentin, J.K. \& Williams, G.L., 1973: Fossil Dinoflagellates: index to genera and species. Geol. Surv. Canada, Paper No. 73-42. 176 pp.

Lentin, J.K. \& Willams, G.L., 1976: A monograph of fossil peridinioid dinoflagellate cysts. Bedford Inst. Ocean. Rep. Ser. BI-R. 75-16, 1-237.

Lentin, J.K. \& Williams, G.L., 1981: Fossil Dinoflagellates: index to genera and species, 1981 edition. Bedford Inst. Ocean. Rep. Ser. BI-R.81-12. 345 pp.

Lentin J.K. \& Williams G.L., 1985: Fossil Dinoflagellates: Index to Gencra and Species, 1985 edition. Can. Tech. Rep. Hydrogr. Ocean Sci. 60. 451 pp.

Leschik, G., 1955: Die Keuperflora von Neuewelt bei Basel. II. Die Iso- und Mikrosporen. Schw. Palaeontol. Abh. 72, 1-70.

Loeblich, A.R. Jr. \& Loeblich, A.R. III, 1968: Index to the Genera, Subgenera and sections of the Pyrrophyta II. Jour. Palaeont. 42 (1), 210-213

Lund J.J., 1977: Rhaetic to Lower Liassic palynology of the onshore south-eastern North Sea Basin. Danm. geol. Unders. II Række 109. $130 \mathrm{pp}$.

Lund, J.J. \& Pedersen, K.R., 1985: Palynology of the marine Jurassic formations in the Vardekløft ravine, Jameson Land, East Greenland. Bull. geol. Soc. Denmark 33 (3-4), 371-399.

Lundblad, B., 1954: Contributions to the geological history of the Hepaticae. Fossil Marchantiales from the Rhaetic-Liassic coalmines of Skromberga (prov, of Scania), Sweden. Sv. Bot. Tidskr. 48(2), 381-417.

Maljavkina, V.S., 1949: Index of spores and pollen, Jurassic-Cretaceous. Trudy VNIGRI 33, 1-137 (in russian).

Michelsen O. 1973: On Liassic holothurian and ostracod assemblages from the Danish Embayment. Danm. geol. Unders. Årbog 1972, $49-68$.

Michelsen, O., 1975: Lower Jurassic biostratigraphy and ostracods of the Danish Embayment. Danm. geol. Unders. II Række 104. 287 $\mathrm{pp}$

Michelsen, O., 1978: Stratigraphy and distribution of Jurassic deposits of the Norwegian-Danish Basin. Danm. geol. Unders. Ser. B, 2.28 pp.

Michelsen, O. \& Bertelsen, F., 1979: Geotermiske reservoirformationer i den danske lagseric. Danm. geol. Unders. Årbog 1978, 151-163.

Morbey, S.J., 1975: The palynostratigraphy of the Rhaetian stage, Upper Triassic in the Kendelbachgraben, Austria. Palaeontographica Abt. B 152(1-3), 1-75.

Morbey, S.J., 1978: Late Triassic and Early Jurassic Subsurface palynostratigraphy in Northwestern Europe. Palinologia, núm. extraord. 1, 355-368.

Mädler, K., 1963: Die figurierten organischen Bestandteile der posidonienschiefer. In Schmitz, H.H.: Zur Kenntnis des nordwestdeutschen Posidonienschiefers. Beih. Geol. Jahrb. 58, 1-119.

Mädler, K., 1964a: Bemerkenswerte Sporenformen aus dem Keuper und unteren Lias. Fortsch. Geol. Rheinld. Westf. 12, 169-200. 
Mädler, K, 1964b: Die geologische Verbreitung von Sporen und pollen in der deutschen Trias. Beih. Geol. Jahrb. 65, 1-147.

Newton, E.T., 1875: On "Tasmanite" and Australian "White Coal". Geol. Mag., ser. 2, 2(8), 337-342.

Nilsson, T., 1958: Über das Vorkommen eines mesozoischen Sapropelgesteins in Schonen. Lunds Univ. Årsskr. N.F. Avd. 2, 54(10). $112 \mathrm{pp}$.

Norris, G., 1965: Triassic and Jurassic Miospores and Acritarchs from the Beacon and Ferrar Groups, Victoria Land, Antarctica. New Zealand Jour. Geol. Geophys. 8(2), 236-277.

Norwood, J.A., Nørvang, A. \& von Elm, C., 1951: Final Report on Gassum No. 1. Danm. geol. Unders. (unpublished report). 134 pp.

Nørvang, A., 1957: The Foraminifera of the Lias series in Jutland, Denmark. Meddr. dansk geol. Foren. 13(5), 1-413.

Orbell, G., 1973: Palynology of the British rhaeto-liassic. Bull. geol. Surv. Gr. Britain 44, 1-44.

Orlowska-Zwolinska, T., 1966: Lower Liassic age of the Wielichowo beds in the light of spore- and pollen analysis (Polish Lowland). Kwart. Geol. Inst. Warsz. 10(4), 1003-1021.

Pautsch, M.E., 1958: Keuper sporomorphs from Swierczyna, Poland. Micropaleontology 4(3), 321-325.

Pedersen, G.K., 1986: Changes in the bivalve assemblage of an early jurassic mudstone sequence (The Fjerritslev Formation in the Gassum No. 1-well). Palaeogeogr. Palaeoclimatol. Palaeoecol. 53, 139-168.

Pedersen, K.R. \& Lund, J.J., 1980: Palynology of the plantbearing Rhaetian to Hettangian Kap Stewart Formation, Scoresby Sund, East Greenland. Rev. Palaeobot. Palynol. 31, 1-69.

Pocock, S.A.J., 1962: Microfloral analysis and age determination of strata at the Jurassic-Cretaceous boundary in the Western Canada Plains. Palaeontographica Abt. B 111(1-3), 1-95

Pocock, S.A.J., 1970: Palynology of the Jurassic sediments of Western Canada. Part I. Terrestrial species. Palaeontographica Abt. B 130(1-2), 12-72

Potonié, R., 1956, 1958, 1960: Synopsis der Gattungen der Sporae dispersae. 1. Teil: Sporites. Beih. Geol. Jahrb. 23. 103 pp; 2. Teil: Sporites (Nachträge), Saccites, Aletes, Praecolpates, Polyplicates, Monocolpates. Beih. Geol. Jahrb. 31. 114 pp; 3. Teil: Nachträge Sporites, Fortsetzung Pollenites. Beih. Geol. Jahrb. 39. 189 pp.

Potonié, R. \& Gelletich, J., 1933: Über Pteridophyten-Sporen einer eozänen Braunkohle aus Dorog in Ungarn. S.B. Gatt. nat. Freunde 33, 517-528.

Potonié, R. \& Kremp, G., 1954: Die Gattungen der paläozoischen Sporae dispersae und ihre Stratigraphie. Geol. Jahrb. 69, 111-194.

Potonié, R. \& Kremp, G., 1955, 1956a, 1956b: Die Sporae dispersae des Ruhrkarbons, ihre Morphographie und Stratigraphie mit ausblicken auf Arten anderer Gebeite und Zeitabschnitte. I. Palaeontographica Abt. B 98, 1-136; II. Palaeontographica Abt. B 99, 85-191; III. Palaeontographica Abt. B 100, 65-121.

Potonié, R. \& Venitz, H., 1934: Zur Mikrobotanik des miozänen Humodils der niederrheinischen Bucht. Arb. Inst. Paläobot. Petrogr. Brennsteine, 5, 5-54.

Reinhardt, P., 1961: Sporae dispersae aus den Rhät Thüringens. Mbr. deutsch. Akad. Wiss. Berlin 3(11/12), 704-711.

Reinhardt, P., 1964: Über die Sporae dispersae der Thüringer Trias. Mbr. deutsch. Akad. Wiss. Berlin 6(1), 46-56.

Reissinger, A., 1950: Die "Pollenanalyse" ausgedehnt auf alle Sedimentgesteine der geologischen Vergangenheit. II Teil. Palaeontographica Abt. B 90(4-6), 99-126.

Reyre, Y., 1970: Stereoscan observations on the pollen genus Classopollis Pflug 1953. Palaeontology 13(2), 303-322.

Riding, J.B., 1984: A palynological investigation of Toarcian to early Aalenian strata from the Blea Wyke area, Ravenscar, North Yorkshire. Proc. Yorkshire Geol. Soc. 45, 109-122.

Rogalska, M., 1954: Spore and pollen analysis of the Liassic coal of Blanowice in Upper Silesia. Inst. Geol. Warschau Bull. 89, 1-46.
Ross, N.E., 1949: Investigations of the Senonian of the Kristianstad District, S. Sweden. I: On a Cretaceous Pollen and Spore Bearing Clay Deposit of Scania. Bull. geol. Inst. Univ. Uppsala 34, 25-46.

Rouse, G., 1957: The Application of a New Nomenclatural Approach to Upper Cretaceous Plant Microfossils from Western Canada. Can. Journ. Bot. 35, 349-375.

Sarjeant, W.A.S., 1963: Fossil dinoflagellates from Upper Triassic sediments. Nature, London 199, 353-354.

Sarjeant, W.A.S., 1967: Observations on the acritarch genus Micrhystridium (Deflandre). Rev. Micropal. 9(4), 201-208.

Sarjeant, W.A.S., 1982: The dinoflagellate cysts of the Gonyaulacysta group: a morphological and taxonomic study. American Association of Stratigraphic Palynologists, Contribution Series 9 , $1-80$.

Schulz, E., 1962: Sporenpaläontologische Untersuchungen zur RhätLias-Grenze in Thüringen und der Altmark. Geologie, Berlin 11 (3), 308-320.

Schulz, E., 1966: Über einige neue Sporae dispersae aus dem älteren Mesophytikum Deutschlands. Geologie, Berlin 15(55), 130-151.

Schulz, E., 1967: Sporenpaläontologische Untersuchungen rätoliassischer Schichten im Zentralteil des Germanischen Beckens. Paläont. Abh. B 2(3), 427-633.

Schulz, E., 1970: Die Sporen der Gattung Stereisporites Thomson \& Pflug 1953 aus dem älteren Mesophytikum des Germanischen Beckens. Paläont. Abh. B, 3(3-4), 683-719.

Schuurman, W.M.L., 1977: Aspects of Late Triassic palynology. 2. Palynology of the "Grés et Schiste à Avicula contorta" and "Argiles de Levallois" (Rhaetian) of northeastern France and southern Luxemburg. Rev. Palaeobot. Palynol. 23, 159-253.

Sorgenfrei, T. \& Buch, A., 1964: Deep Tests in Denmark 1935-1959. Danm. geol. Unders. III Række 36. 146 pp.

Srivastava, S.K., 1963: Polospores from Jurassics of Rajasthan, India. Nature, Lond. 198(4887), 1323-1324.

Srivastava, S.K., 1976: The fossil pollen genus Classopollis. Lethaia 9, 437-457.

Stover, L.E. \& Evitt, W.R., 1978: Analyses of pre-Pleistocene organic-walled dinoflagellates. Stanford Univ. Publ., Geol. Sci., 15, $1-300$.

Tappan, H., 1980: The Paleobiology of Plant Protists. W.H. Freeman \& Co., San Francisco. 1028 pp.

Thiergart, F., 1949: Der stratigraphische Wert mesozoischer Pollen und Spores. Palaeontographica Abt. B 89, 1-34.

Thomson P.W. \& Pflug, H., 1953: Pollen und Sporen des Mitteleuropäischen Tertiärs. Palaeontographica Abt. B 94(1-4), 1-138

Tralau, H., 1968: Botanical investigations into the fossil flora of Eriksdal in Fyledalen, Scania. II. The Middle Jurassic Microflora. Sver, geol. Unders. Ser. C. 633. 185 pp.

Tschudy, R.H., 1969: The plant kingdom and its palynological representation. In: Tschudy, R.H. \& Scott, R.A.(eds.), 1969: Aspects of Palynology, Wiley, New York, 5-34.

Vail, P.R., \& Todd, R.G., 1981: Northern North Sea Jurassic unconformities, chronostratigraphy and sea-level changes from seismic stratigraphy. In: Illing, L.V. \& Hobson, G.D. (eds.), 1981: Petroleum Geology of the Continental shelf of Northwest Europe. Heyden, London, 216-235.

Vasard Nielsen, M., in prep.: Palynological investigation of Upper Triassic deposits in the well Gassum No. 1, Jutland, Denmark.

Warren, J.S., 1973: Form and variation of the dinoflagellate Sirmiodinium grossi Alberti, from the Upper Jurassic and Lower Cretaceous of California. Jour. Palaeont. 47, 101-114.

Wilson, L.R. \& Webster, R.M., 1946: Plant microfossils from a Fort Union coal of Montana. Amer. Journ. Bot. 33(4), 271-278.

Woollam, R. \& Riding, J.B., 1983: Dinoflagellate cyst zonation of the English Jurassic. Inst. Geol. Sci. Rep. 83/2. 42 pp.

Ziegler, P.A., 1982: Geological Atlas of Western and Central Europe. Shell Internat. Pet. Maatschappij, b.v. 130 pp. 


\section{Plates}

The number of the sample from which the illustrated specimen was recorded is given in the figure text.

The slides containing the illustrated specimens, together with a list of stage coordinates for the Leitz Wetzlar microscope used, are available from the Geological Institute, University of Aarhus, Denmark. 


\section{PLATE 1}

Magnifications: $x 1000$

Fig. 1. Deltoidospora toralis (Leschik) Lund. Sample GA-7.

Fig. 2. Deltoidospora toralis (Leschik) Lund. Sample GA-7.

Fig. 3. Deltoidospora crassexina (Nilsson) Lund. Sample GA-22.

Fig. 4. Deltoidospora minor (Couper) Pocock. Sample GA-38.

Fig. 5. Intrapunctisporis toralis (Leschik) Lund. Sample GA-4.

Fig. 6. Cibotiumspora jurienensis (Balme) Filatoff. Sample GA-11.

Fig. 7. Punctatisporites globosus (Leschik) Lund. Sample GA-2.

Fig. 8. Punctatisporites major (Couper) Kedves \& Simoncsics. Sample GA-2.

Fig. 9. Retusotriletes mesozoicus Klaus. Sample GA-2.

Fig. 10. Calamospora tener (Leschik) Mädler. Sample GA-8.

Fig. 11. Calamospora sp. Sample GA-16.

Fig. 12. Stereisporites stereoides (Potonié \& Venitz) Pflug. Sample GA-11.

Fig. 13. Stereisporites antiquasporites (Wilson \& Webster) Dettmann. Sample GA-41. 
Plate 1
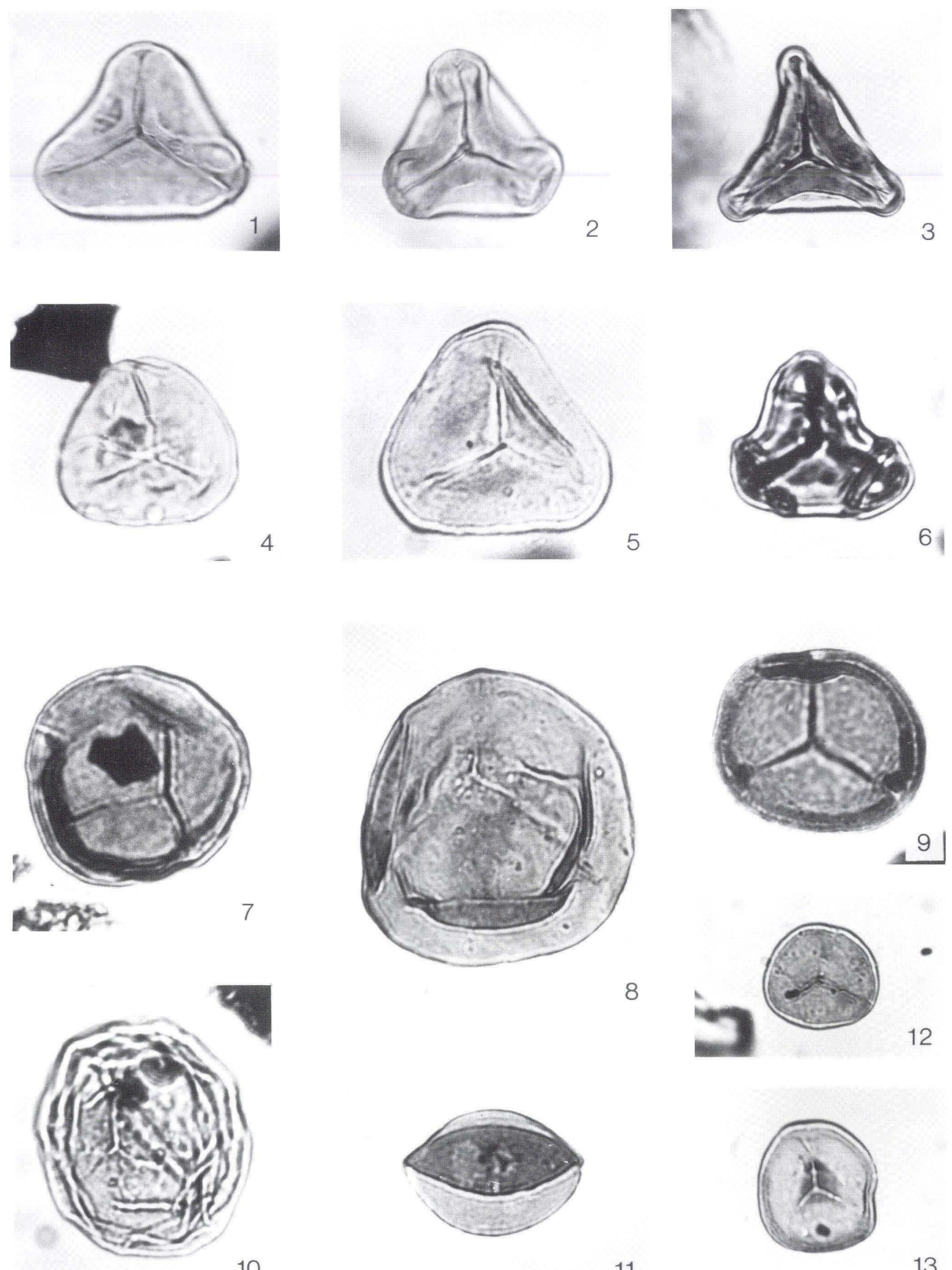

8
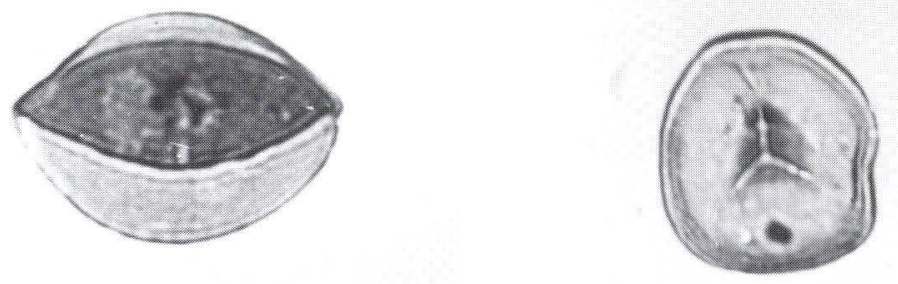


\section{PLATE 2}

Magnifications: x1000

Fig. 1. Stereisporites punctus (Klaus) Krutzsch. Sample GA-34.

Fig. 2. Stereisporites cicatricosus (Rogalska) Schulz. Sample GA-39.

Fig. 3. Stereisporites cf. hauterivensis Döring. Sample GA-69.

Fig. 4. Stereisporites cf. seebergensis Schulz. Sample GA-44.

Fig. 5. Trachysporites fuscus Nilsson. Sample GA-15.

Fig. 6. Trachysporites asper Nilsson. Sample GA-24.

Fig. 7. Trachysporites ef. sparsus (Bharadwaj \& Singh) Lund. Sample GA-2.

Fig. 8. Conbaculatisporites mesozoicus Klaus. Sample GA-1.

Fig. 9. Conbaculatisporites spinosus (Mädler) Lund. Sample GA-38.

Fig. 10. Baculatisporites oppressus (Leschik) Lund. Sample GA-1.

Fig. 11. Baculatisporites wellmanii (Couper) Krutzsch. Sample GA-29.

Fig. 12. Baculatisporites comaumensis (Cookson) Potonié. Sample GA-5 
Plate 2
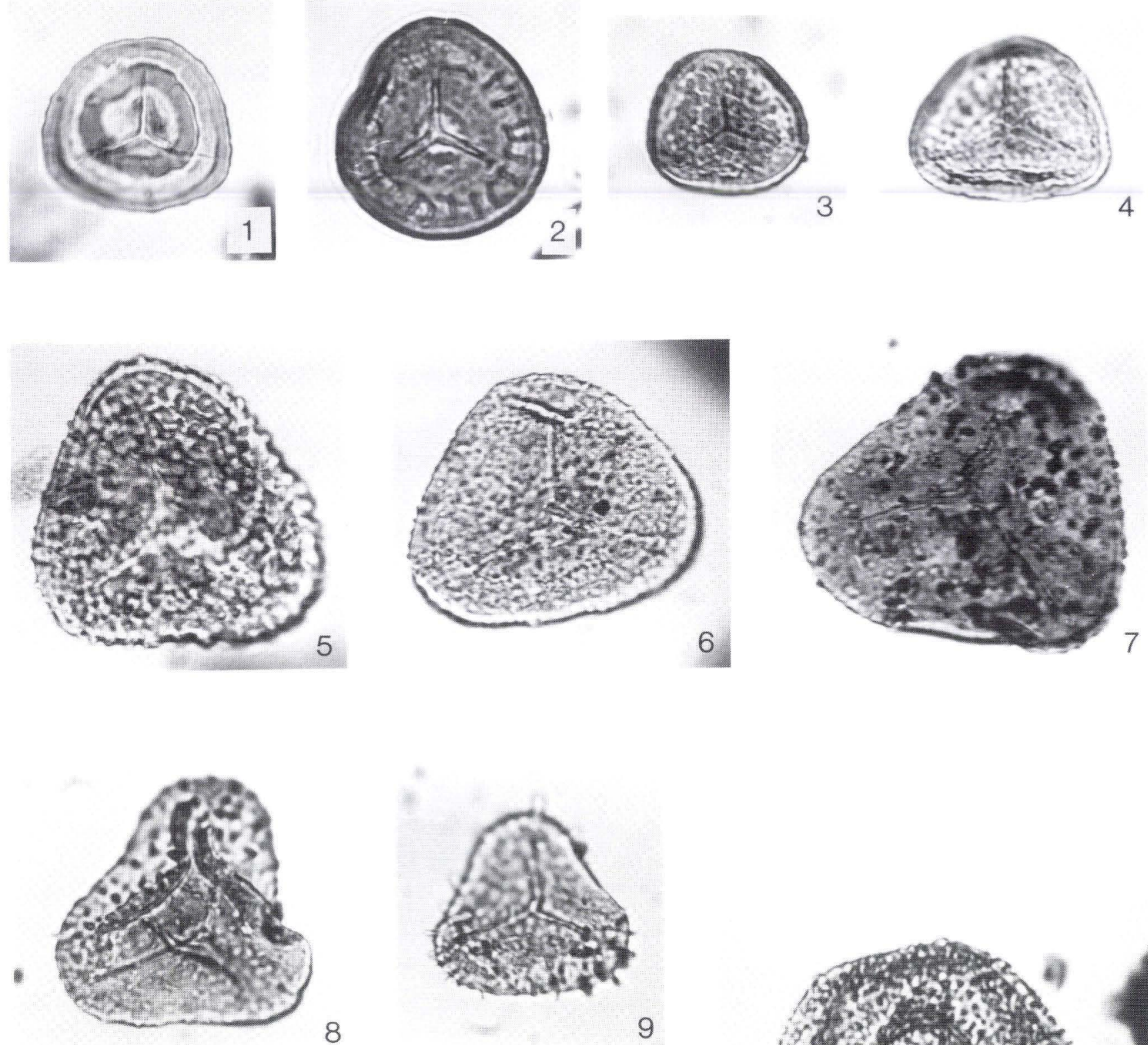

8
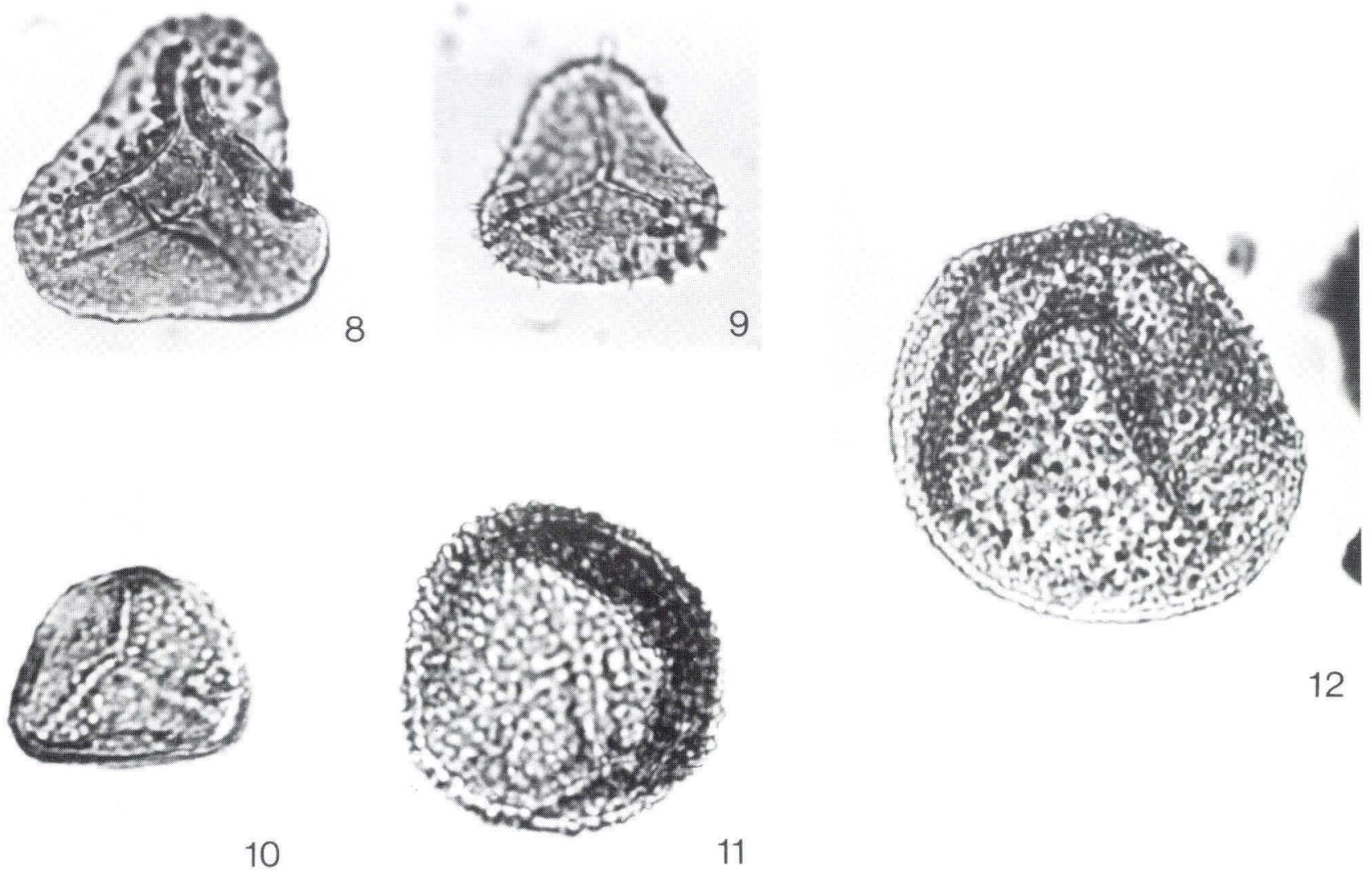


\section{PLATE 3}

Magnifications: x1000

Fig. 1. Apiculatisporis ovalis (Nilsson) Norris. Sample GA-1.

Fig. 2. Anapiculatisporites spiniger (Leschik) Reinhardt. Sample GA-15.

Fig. 3. Anapiculatisporites telephorus (Pautsch) Klaus. Sample GA-1.

Fig. 4. Acanthotriletes varius Nilsson. Sample GA-1.

Fig. 5. Uvaesporites argenteaeformis (Bolkhovitina) Schulz. Tetrad. Sample GA-24.

Fig. 6. Uvaesporites argenteaeformis (Bolkhovitina) Schulz. Sample GA-50.

Fig. 7. Iraquispora laevigata (Mädler) Lund. Sample GA-3.

Fig. 8. Lycopodiumsporites semimuris Danzé-Corsin \& Laveine. Distal side (high focus). Sample GA-7.

Fig. 9. Same specimen as fig. 8. Proximal side (low focus).

Fig. 10. Manumia variverrucata Couper emend. Hoelstad. Sample GA-65.

Fig. 11. Lycopodiumsporites austroclavatidites (Cookson) Potonié. Sample GA-38.

Fig. 12. Lycopodiumsporites clavatoides (Couper) Tralau. Sample GA-33. 
Plate 3

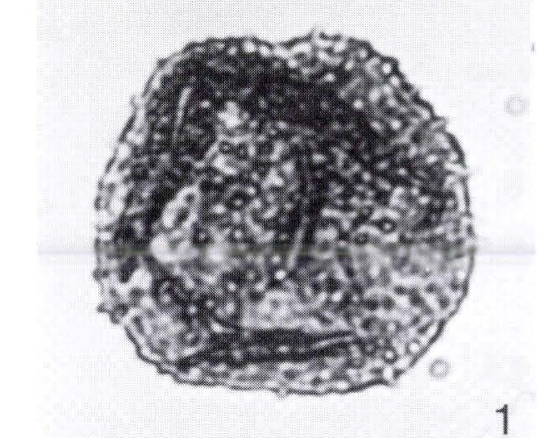

1

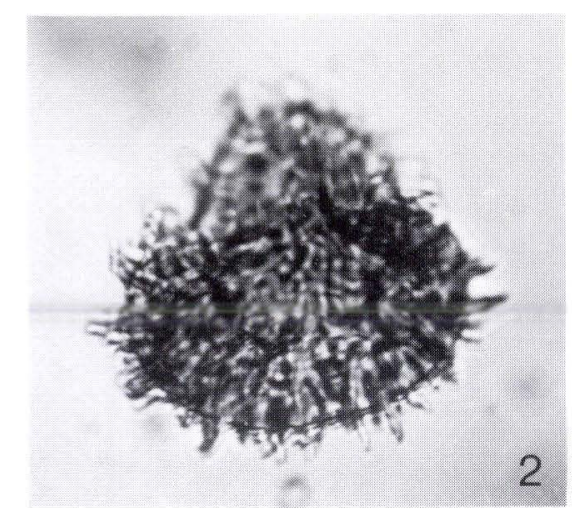

a

2
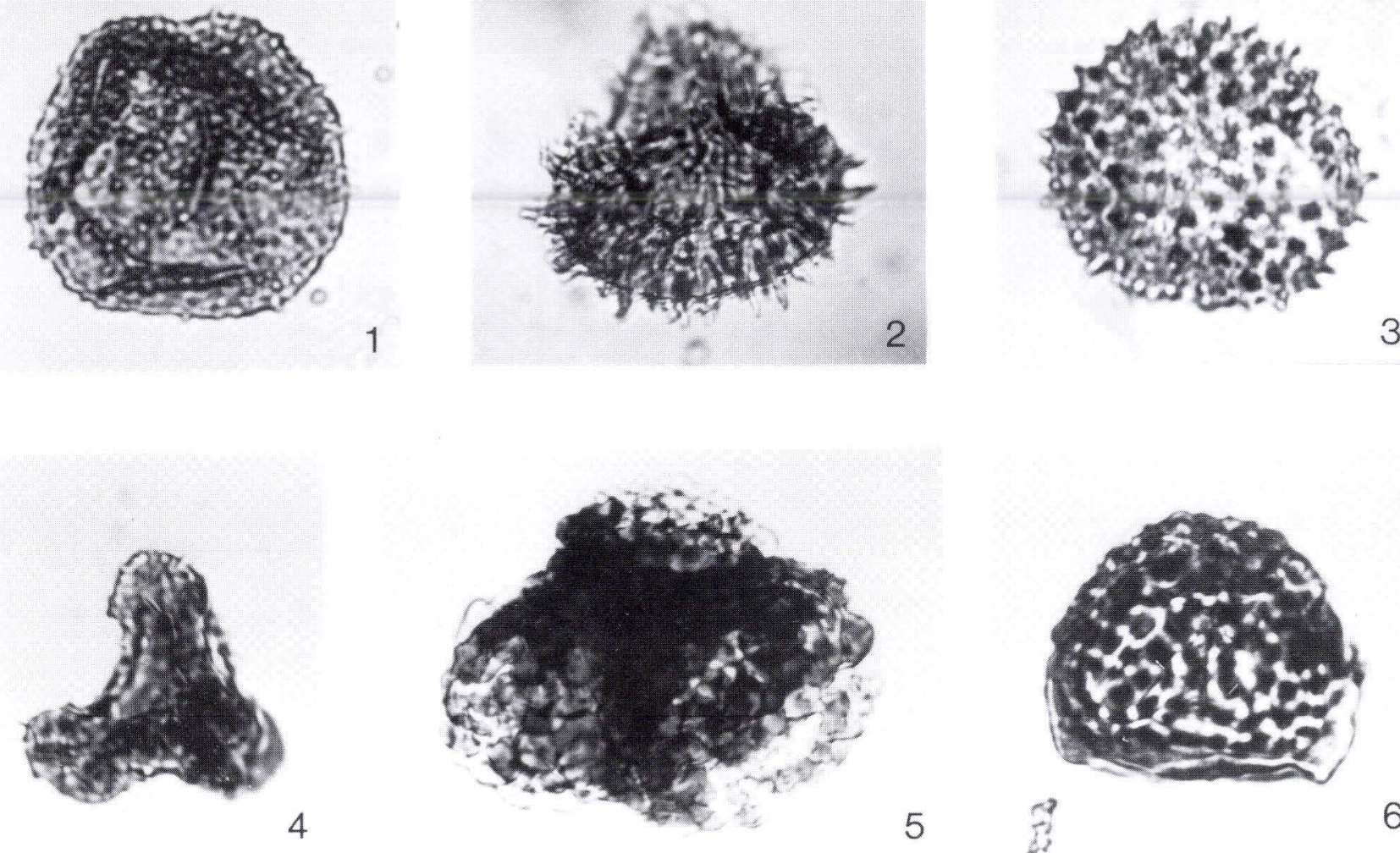

5
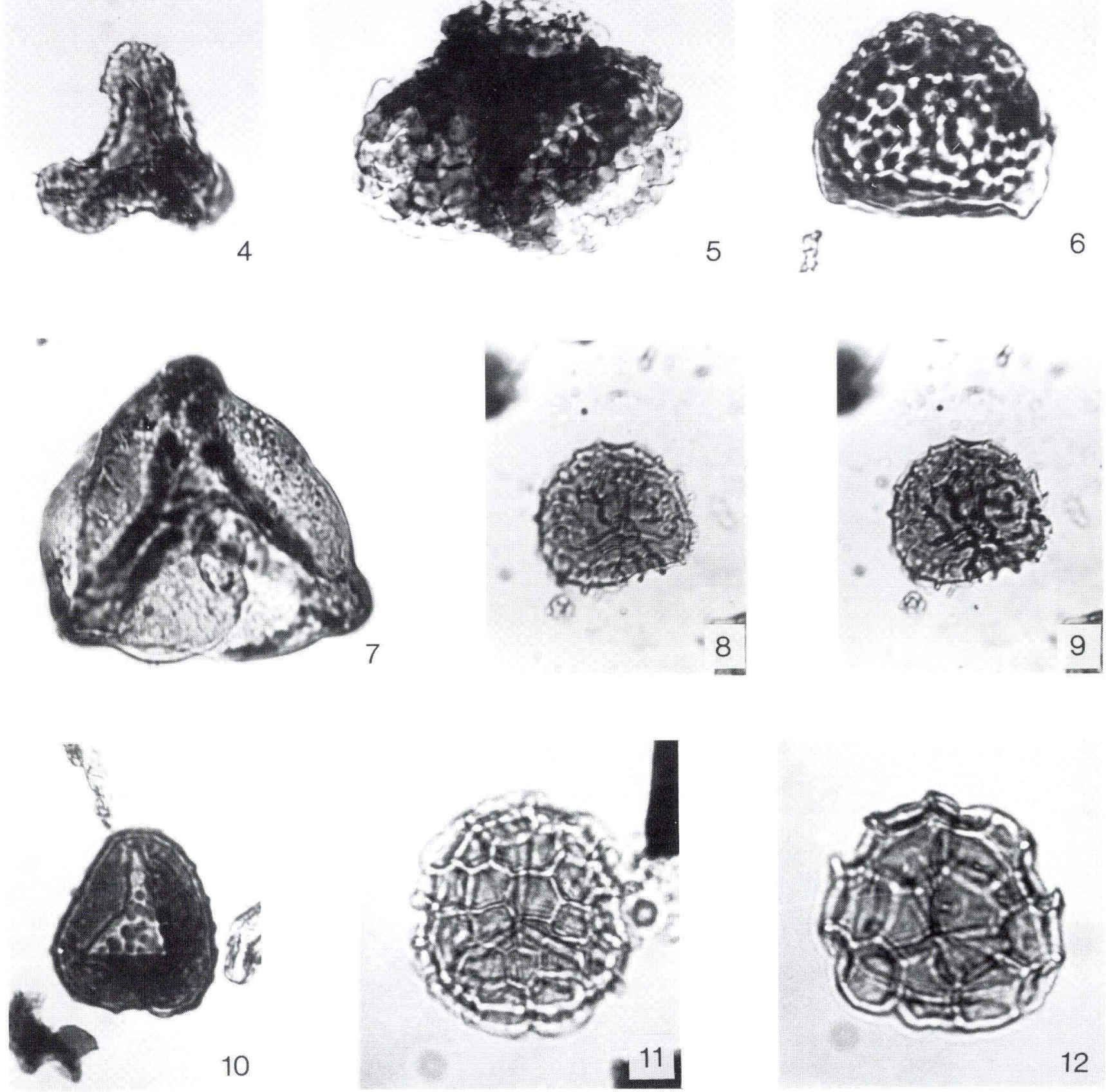


\section{PLATE 4}

Magnifications: x1000

Fig. 1. Contignisporites problematicus (Couper) Döring. Proximal side (high focus). Sample GA-2.

Fig. 2. Same specimen as fig. 1. Distal side (low focus).

Fig. 3. Contignisporites problematicus (Couper) Döring. Sample GA-1.

Fig. 4. Staplinisporites telatus (Balme) Döring. Proximal side (high focus). Sample GA-65.

Fig. 5. Same specimen as fig. 4. Distal side (low focus).

Fig. 6. Cicatricosisporites sp. Sample GA-71.

Fig. 7. Zebrasporites interscriptus (Thiergart) Klaus. Proximal side (high focus). Sample GA-7.

Fig. 8. Same specimen as fig. 7. Distal side (low focus).

Fig. 9. Platyptera trilingua (Horst) Schulz. Sample GA-47.

Fig. 10. Cf. Lycopodiacidites. Sample GA-34.

Fig. 11. Triancoraesporites ancorae (Reinhardt) Schulz. Sample GA-1.

Fig. 12. Lycopodiacidites rugulatus (Couper) Schulz. Sample GA-33. 
Plate 4
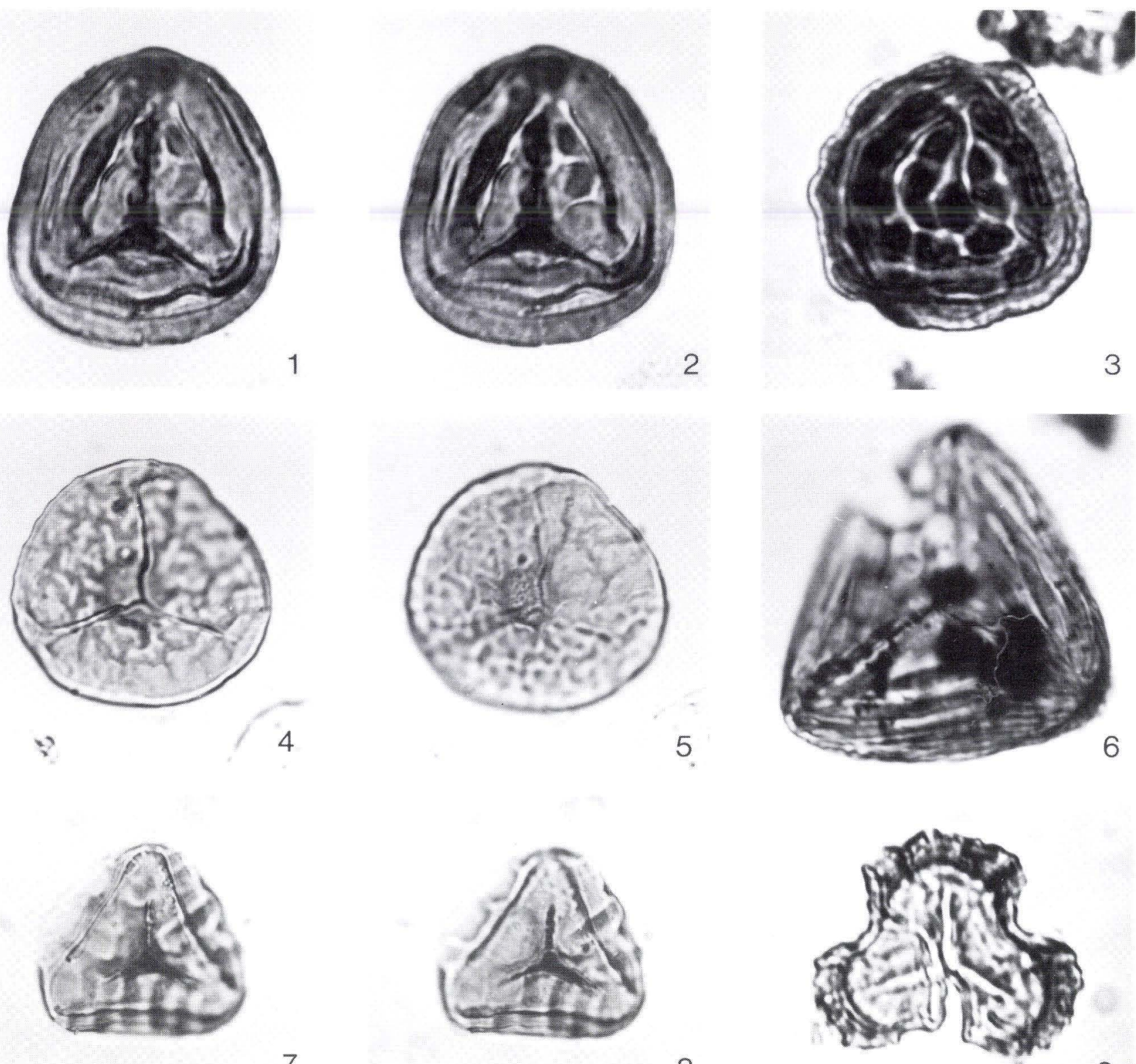

8
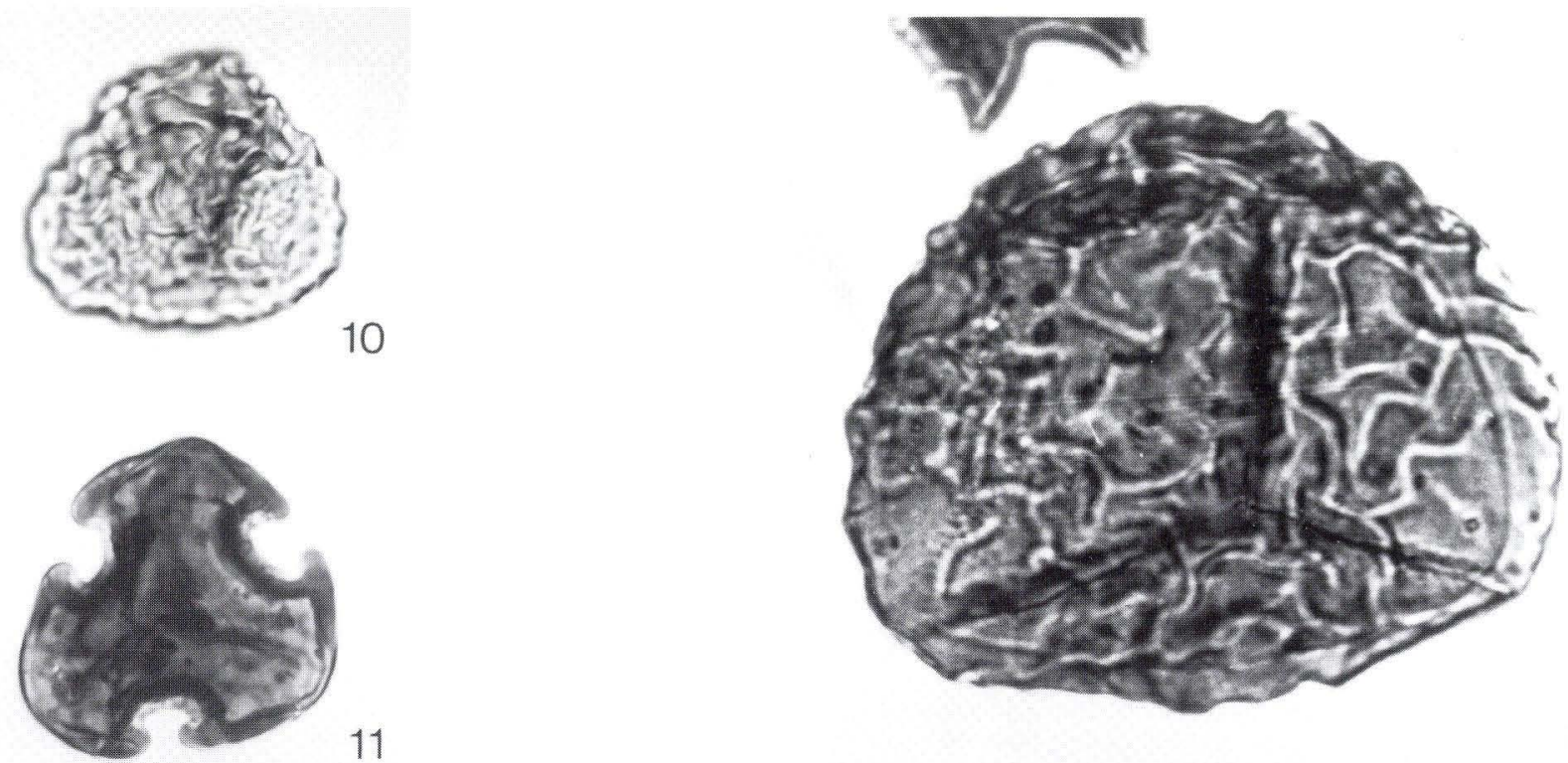


\section{PLATE 5}

Magnifications: x1000

Fig. 1. Densosporites fissus (Reinhardt) Schulz. Sample GA-4.

Fig. 2. Cingutriletes infrapunctus (Schulz) Morbey. Sample GA-42.

Fig. 3. Trilobosporites sp. Sample GA-70.

Fig. 4. Gleicheniidites senonicus Ross. Sample GA-69.

Fig. 5. Gleicheniidites conspiciendus (Bolkhovitina) Krutzsch. Sample GA-69.

Fig. 6. Densoisporites microrugulatus Brenner. Sample GA-66.

Fig. 7. Limbosporites lundbladii Nilsson. Sample GA-3.

Fig. 8. Lycospora salebrosacea (Maljavkina) Schulz. Sample GA-57.

Fig. 9. Cingulizonates rhaeticus (Reinhardt) Schulz. Sample GA-3. 
Plate 5
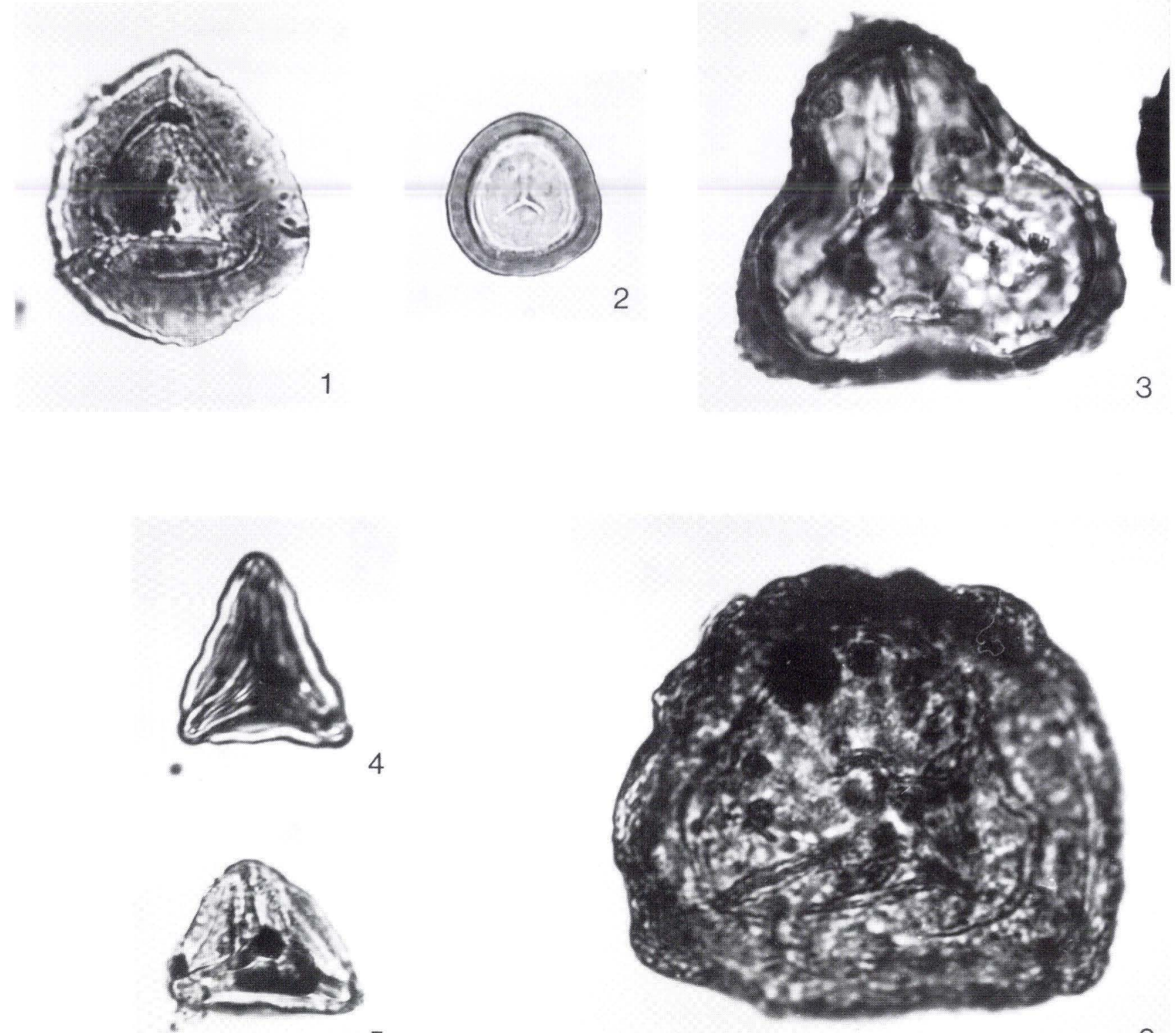

5

6
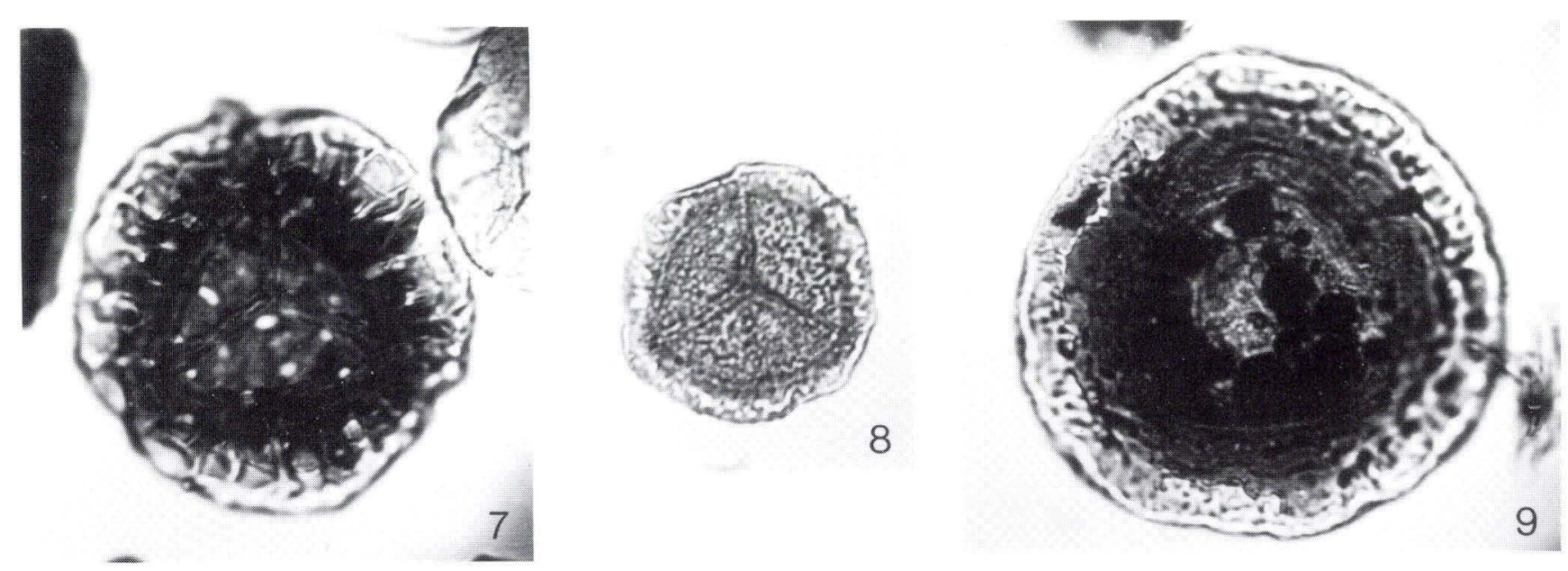


\section{PLATE 6}

Magnifications: x1000

Fig. 1. Heliosporites altmarkensis Schulz. Sample GA-16.

Fig. 2. Heliosporites altmarkensis Schulz. Tetrad. Sample GA-12.

Fig. 3. Laevigatosporites sp. Sample GA-24.

Fig. 4. Marattisporites scabratus Couper. Sample GA-23.

Fig. 5. Aratrisporites minimus Schulz. Sample GA-4.

Fig. 6. Trisaccate, undet. Sample GA-49.

Fig. 7. Monosaccate, undet. Sample GA-1.

Fig. 8. Vitreisporites pallidus (Reissinger) Nilsson. Sample GA-46.

Fig. 9. Vitreisporites pallidus (Reissinger) Nilsson. Trisaccate specimen. Sample GA-7. 
Plate 6
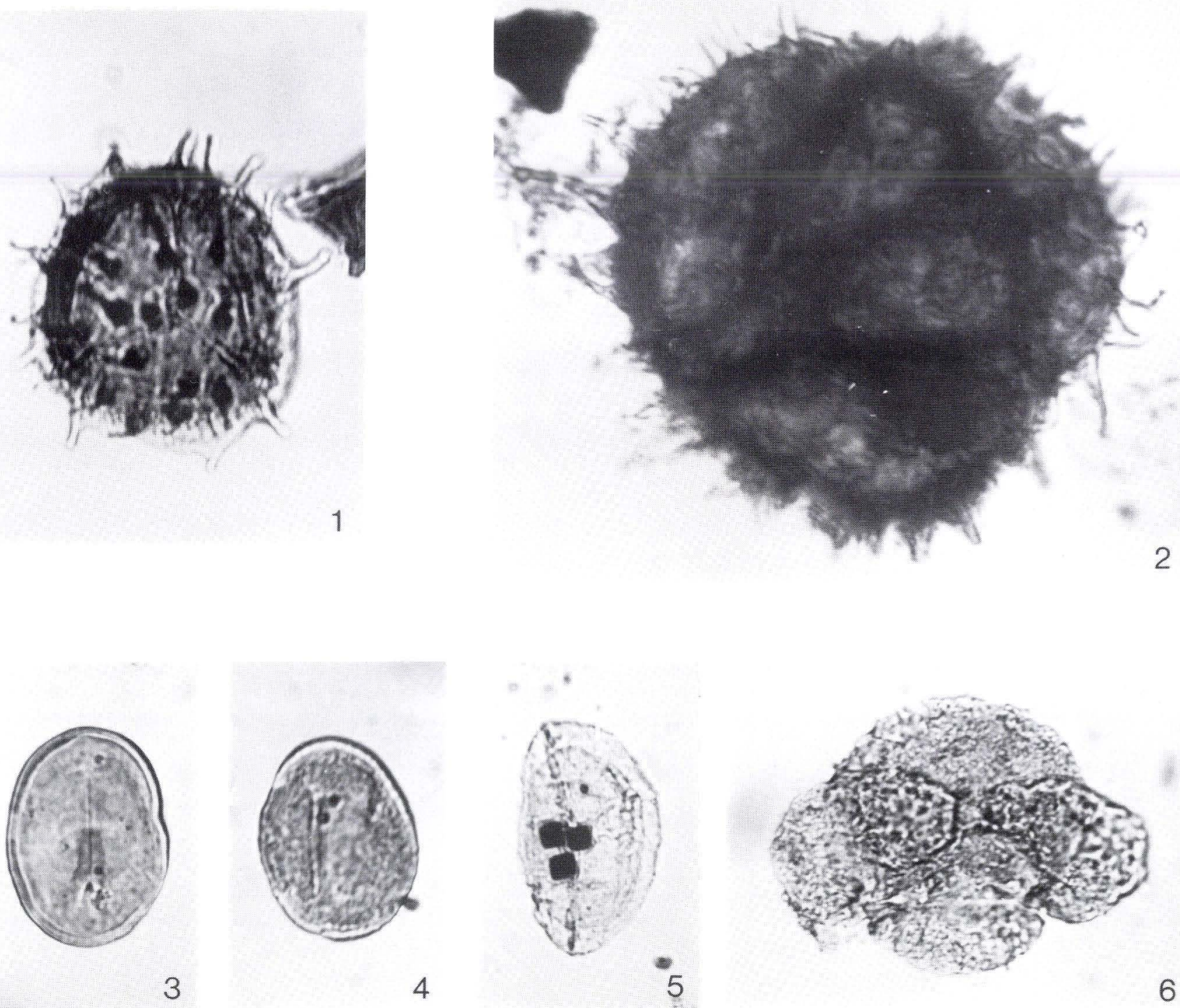

3

4

6
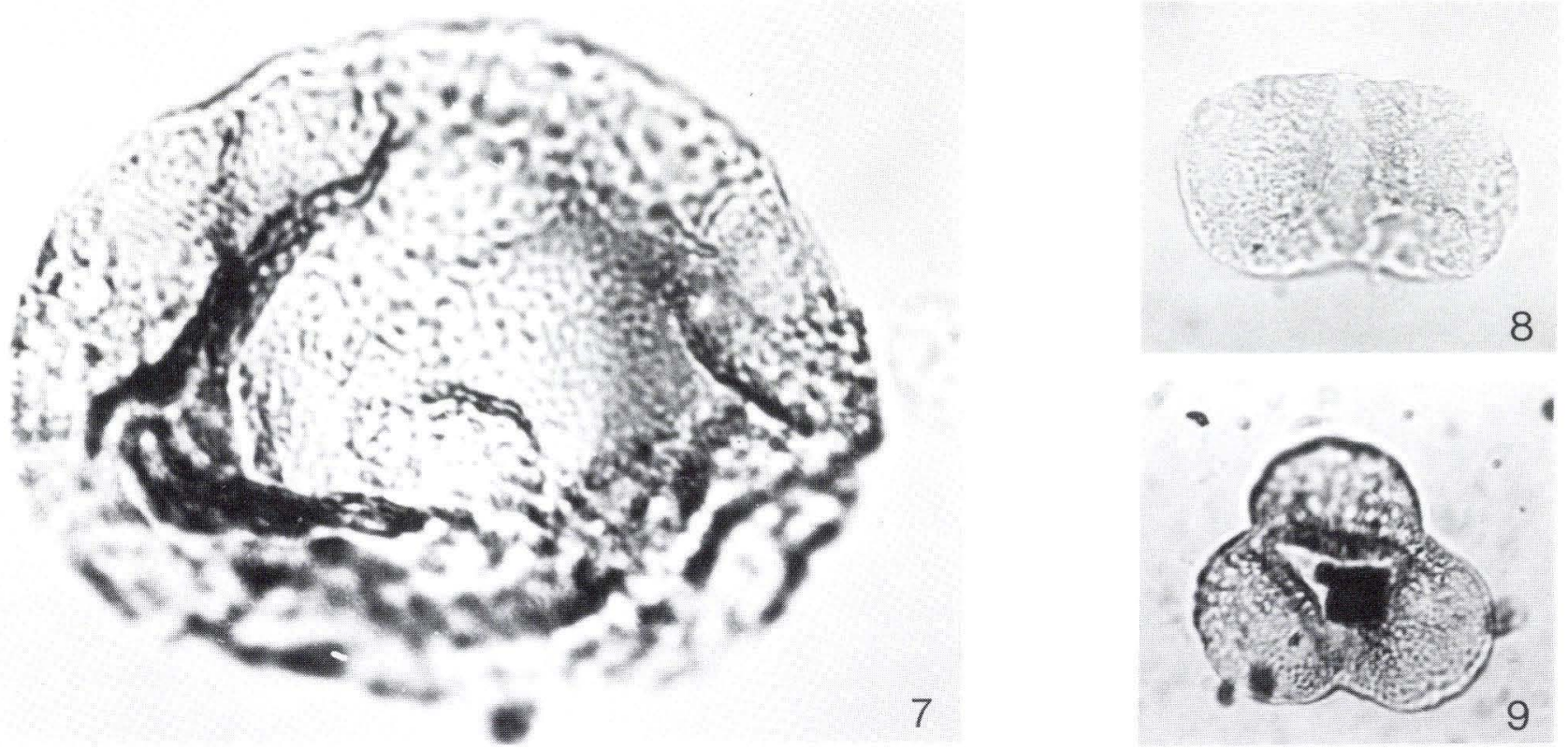


\section{PLATE 7}

Magnifications: $x 1000$ except for fig. 5 , which is $x 500$.

Fig. 1. Pinuspollenites minimus (Couper) Kemp. Sample GA-4.

Fig. 2. Pinuspollenites minimus (Couper) Kemp. Sample GA-11.

Fig. 3. Pinuspollenites pinoides (Nilsson) Lund. Sample GA-16.

Fig. 4. Umbrosaccus keuperianus Mädler. Sample GA-49.

Fig. 5. Cf. Umbrosaccus. NOTICE: Magnification x500. Sample GA-39.

Fig. 6. Schismatosporites ovalis Nilsson. Sample GA-4.

Fig. 7. Quadraeculina anellaeformis Maljavkina. Sample GA-15.

Fig. 8. Protopinus cf. scanicus Nilsson. Sample GA-33. 

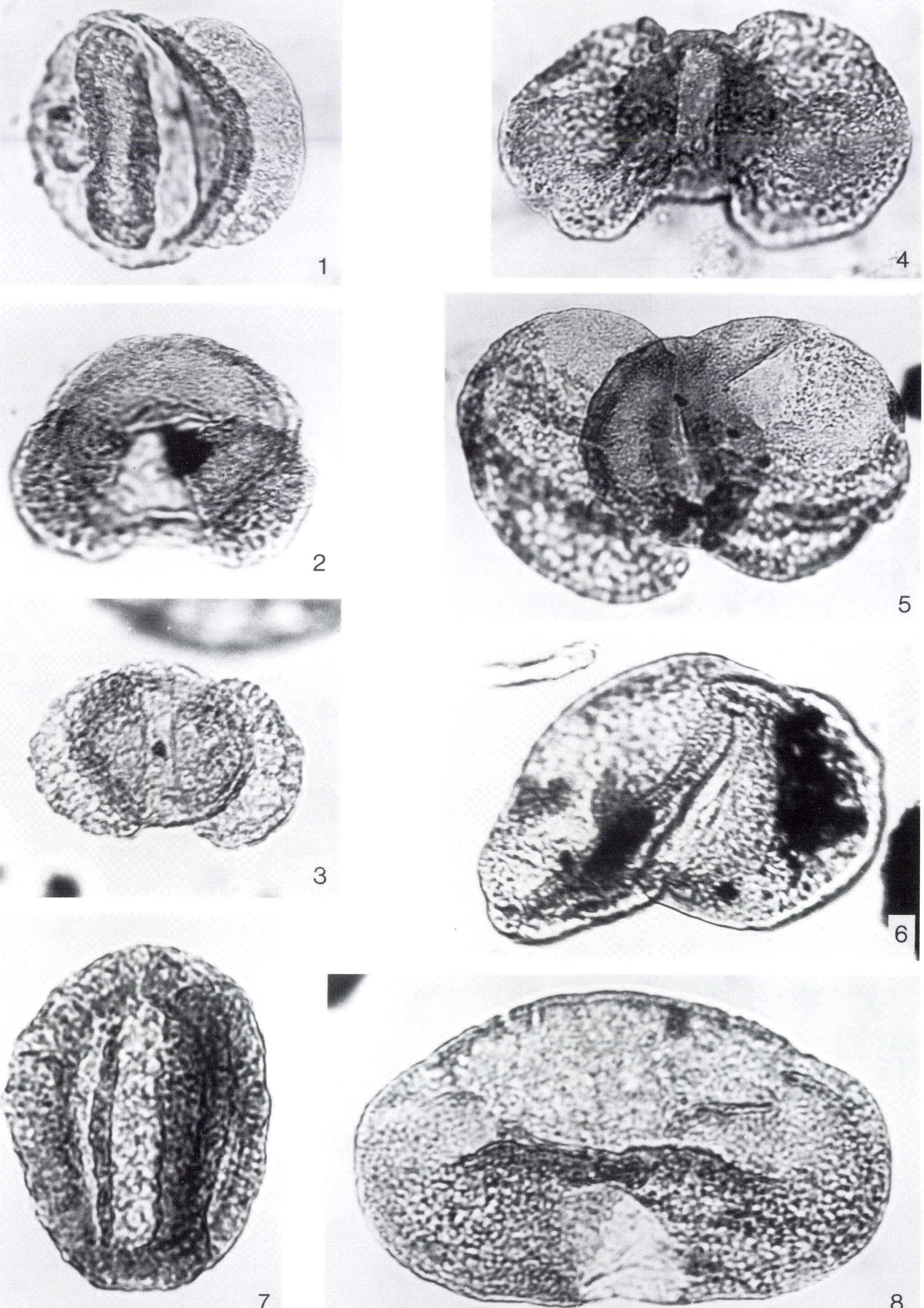

3

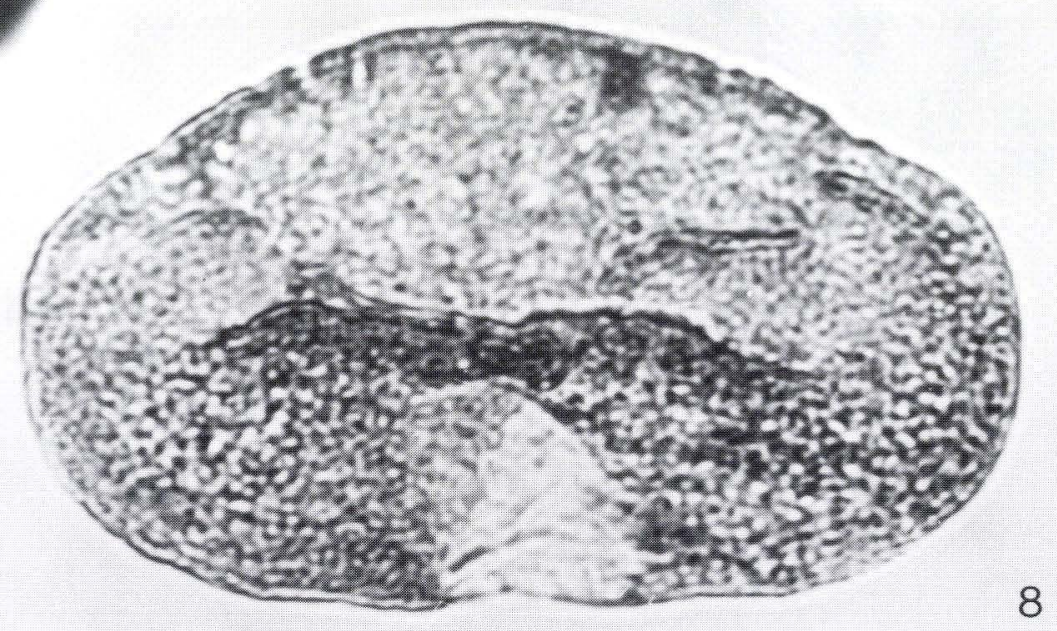




\section{PLATE 8}

Magnifications: $\mathrm{x} 1000$ except for fig. 5, which is $\mathrm{x} 500$.

Fig. 1. Alisporites radialis (Leschik) Lund. Sample GA-2.

Fig. 2. Alisporites robustus Nilsson. Sample GA-24.

Fig. 3. Alisporites thomasii (Couper) Nilsson. Sample GA-29.

Fig. 4. Alisporites microsaccus (Couper) Pocock. Sample GA-33.

Fig. 5. Alisporites grandis (Cookson) Dettmann. NOTICE: Magnification x500. Sample GA-38.

Fig. 6. Podocarpidites cf. biformis Rouse. Sample GA-20. 

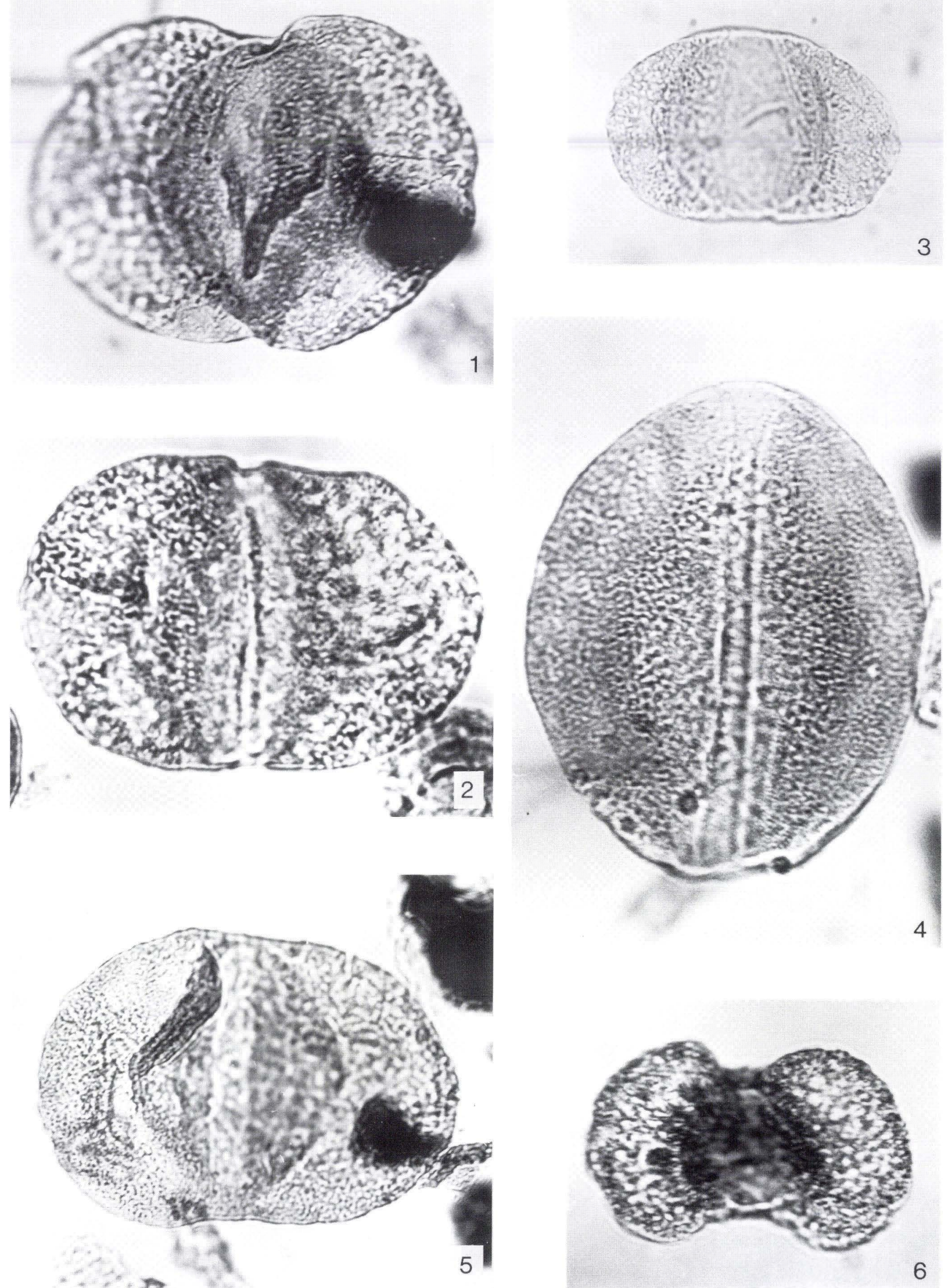


\section{PLATE 9}

Magnifications: x1000

Fig. 1. Araucariacites australis. Sample GA-4.

Fig. 2. Perinopollenites elatoides Couper. Sample GA-40.

Fig. 3. Cupressacites sp. Sample GA-40.

Fig. 4. Cerebropollenites macroverrucosus (Thiergart) Schulz. Sample GA-21.

Fig. 5. Cerebropollenites macroverrucosus (Thiergart) Schulz. Sample GA-48.

Fig. 6. Exesipollenites tumulus Balme. Sample GA-67.

Fig. 7. Cerebropollenites thiergartii Schulz. Sample GA-56.

Fig. 8. Spheripollenites subgranulatus Couper. Sample GA-55.

Fig. 9. Spheripollenites psilatus Couper. Sample GA-29. 

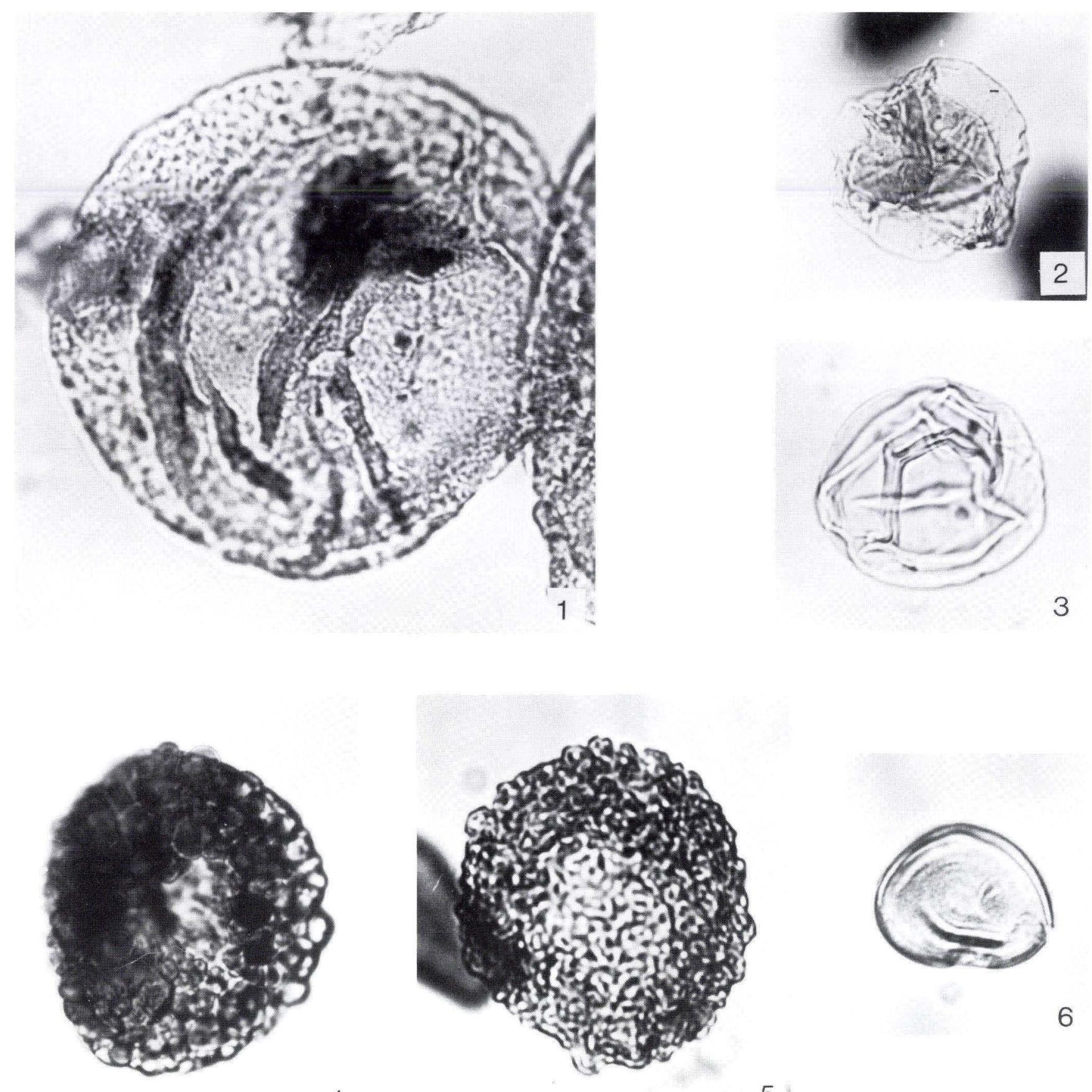

4

5
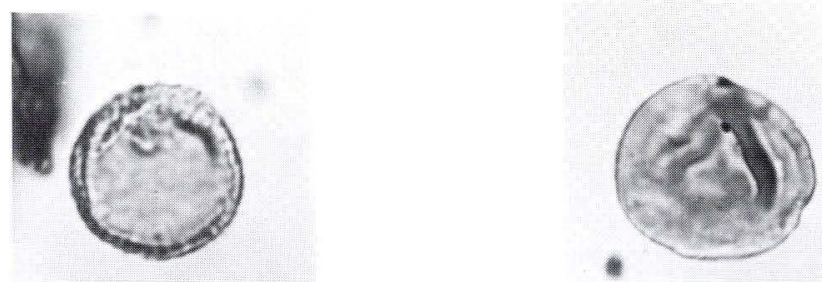

8 


\section{PLATE 10}

Magnifications: x1000

Fig. 1. Callialasporites microvelatus Schulz. Sample GA-59.

Fig. 2. Callialasporites trilobatus (Balme) Dev. Sample GA-71.

Fig. 3. Callialasporites segmentatus (Balme) Srivastava. Sample GA-65.

Fig. 4. Chasmatosporites hians Nilsson. Sample GA-60.

Fig. 5. Chasmatosporites elegans Nilsson. Sample GA-36.

Fig. 6. Chasmatosporites elegans Nilsson. Sample GA-39.

Fig. 7. Chasmatosporites apertus (Rogalska) Nilsson. Sample GA-8.

Fig. 8. Chasmatosporites apertus (Rogalska) Nilsson. Sample GA-20.

Fig. 9. Monosulcites minimus Cookson. Sample GA-8.

Fig. 10. Monosulcites punctatus Orlowska-Zwolinska. Sample GA-34. 
Plate 10
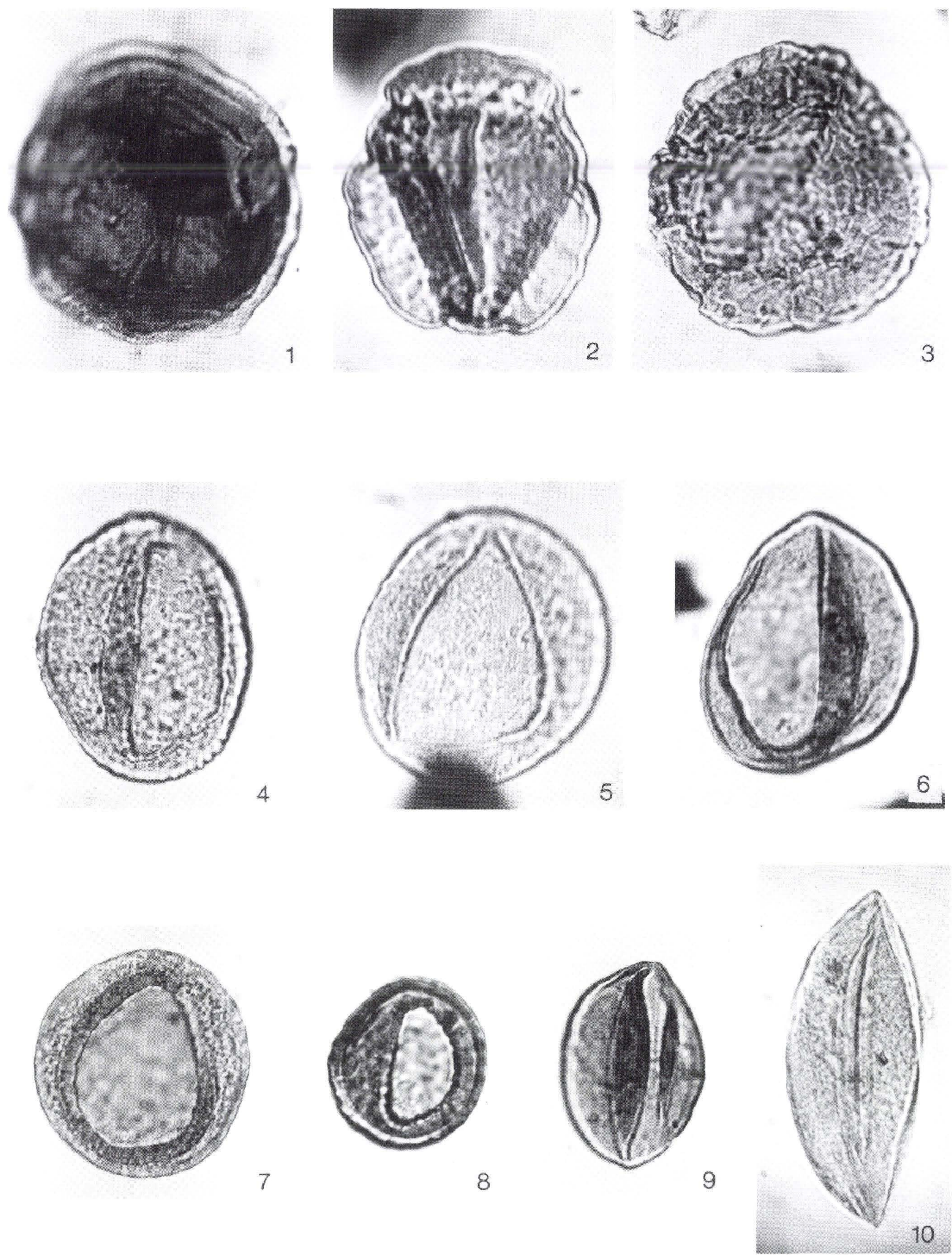


\section{PLATE 11}

Magnifications: x1000

Fig. 1. Ricciisporites tuberculatus Lundblad. Tetrad. Sample GA-53.

Fig. 2. Clavatipollenites hughesii Couper. Sample GA-26.

Fig. 3. Monosulcites cf. punctatus Orlowska-Zwolinska. Sample GA-28.

Fig. 4. Eucommiidites troedssonii Erdtman. Sample GA-40.

Fig. 5. Eucommiidites minor Groot \& Penny. Sample GA-30.

Fig. 6. Corollina torosus (Reissinger) Klaus emend. Cornet \& Traverse. Tetrad. Sample GA-4.

Fig. 7. Corollina torosus (Reissinger) Klaus emend. Cornet \& Traverse. Sample GA-20.

Fig. 8. Corollina torosus (Reissinger) Klaus emend. Cornet \& Traverse. Sample GA-34.

Fig. 9. Corollina sp. 1. Sample GA-67.

Fig. 10. Corollina sp. 2. Sample GA-67. 

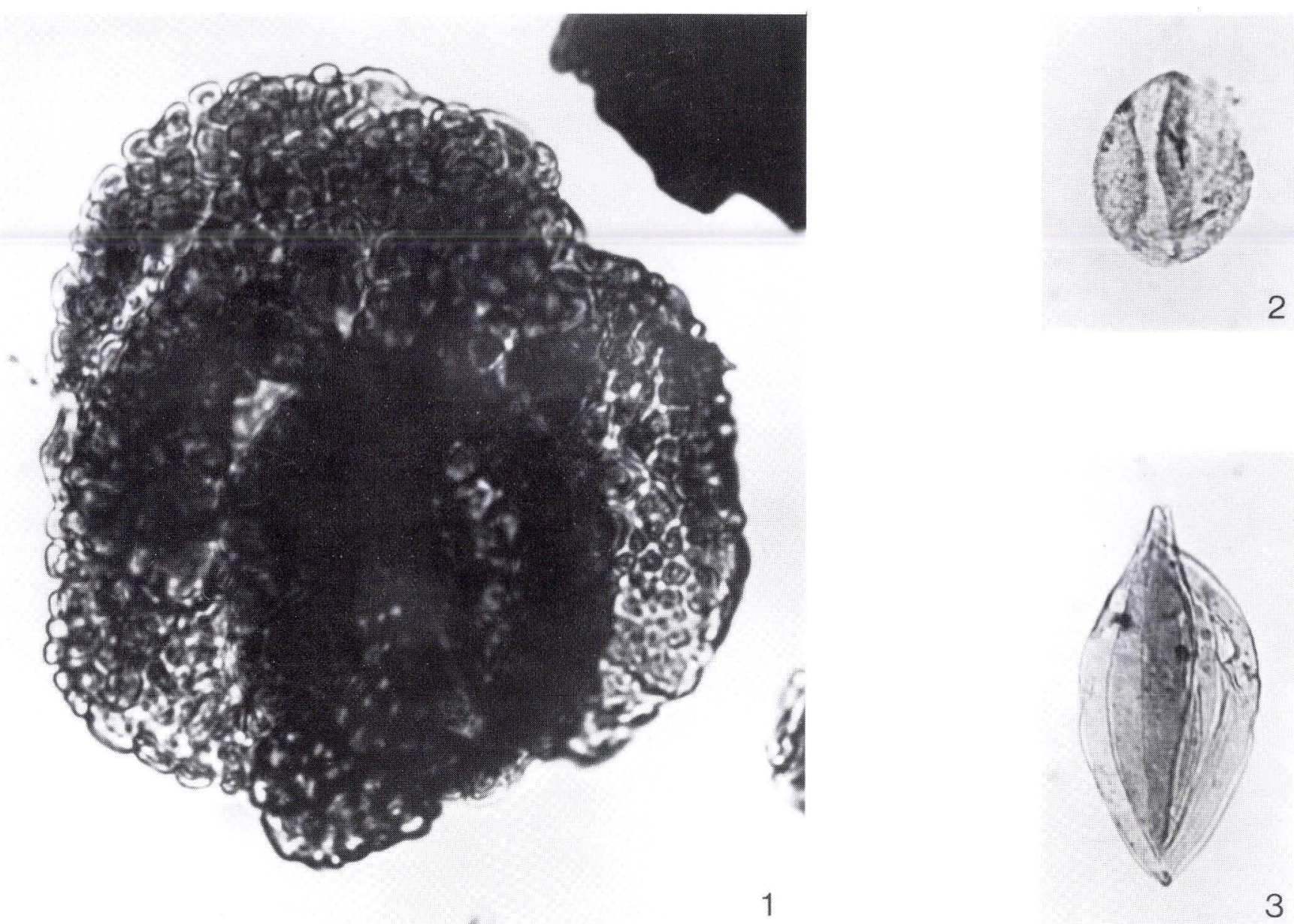

2
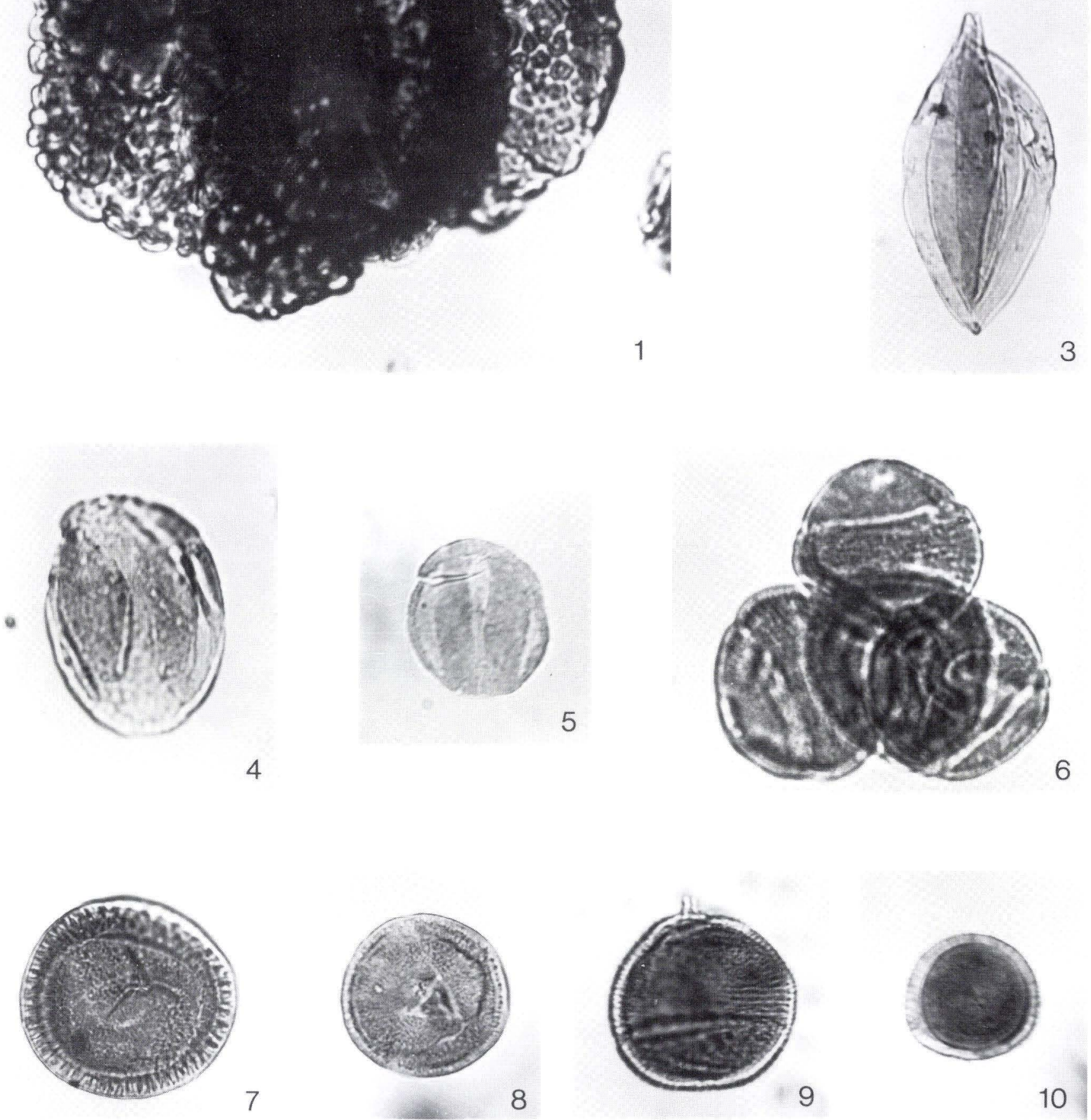


\section{PLATE 12}

Magnifications: x1000

Fig. 1. Leiosphaeridia sp. Sample GA-42.

Fig. 2. Halosphaeropsis sp. Sample GA-12.

Fig. 3. Veryhachium sp. Sample GA-16.

Fig. 4. Micrhystridium sp., type 1. Sample GA-36.

Fig. 5. Micrhystridium sp., type 2. Sample GA-32.

Fig. 6. Micrhystridium sp., type 3. Sample GA-17.

Fig. 7. Foraminiferal test-linings. Sample GA-71.

Fig. 8. Micrhystridium sp., type 4. Sample GA-42.

Fig. 9. Micrhystridium sp., type 5. Sample GA-32. 
Plate 12

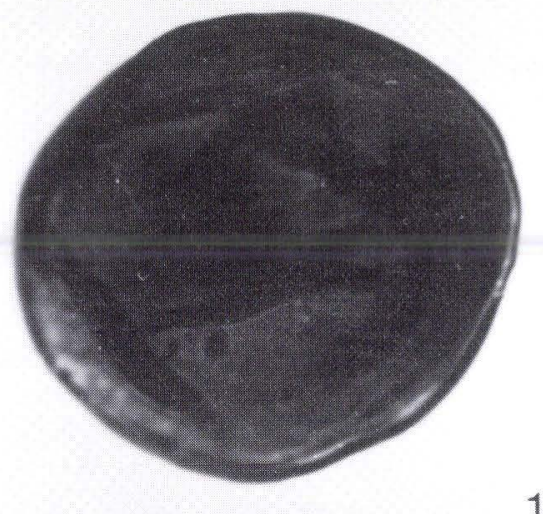

1

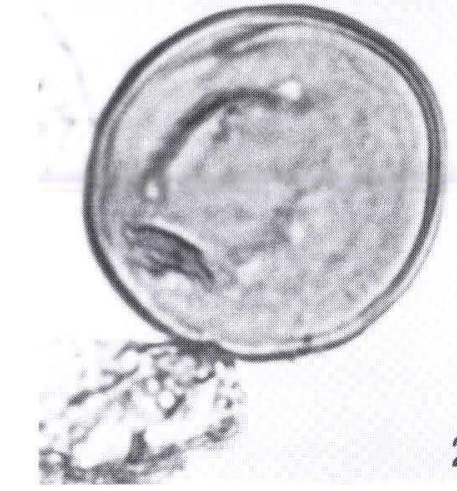

2

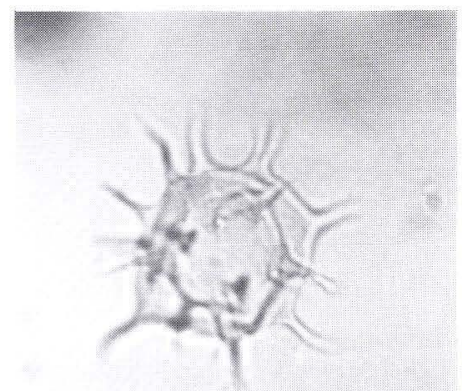

5
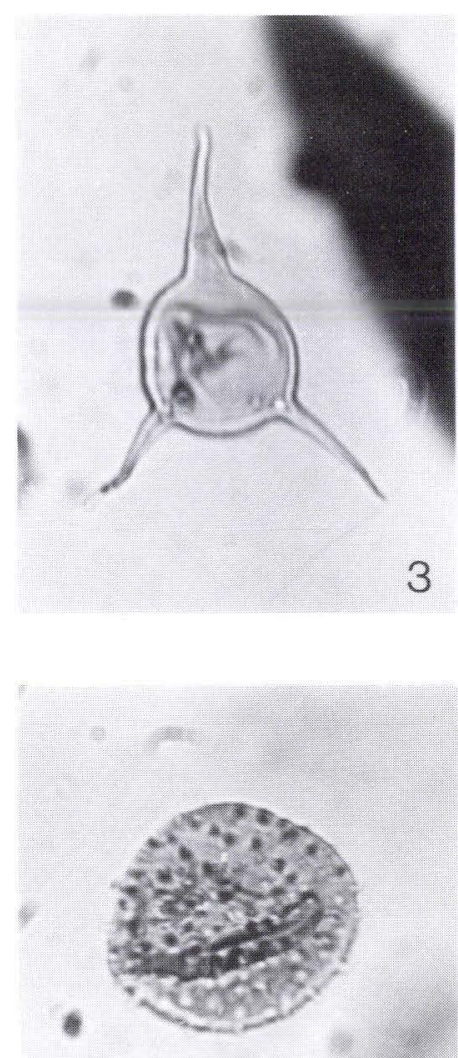

6
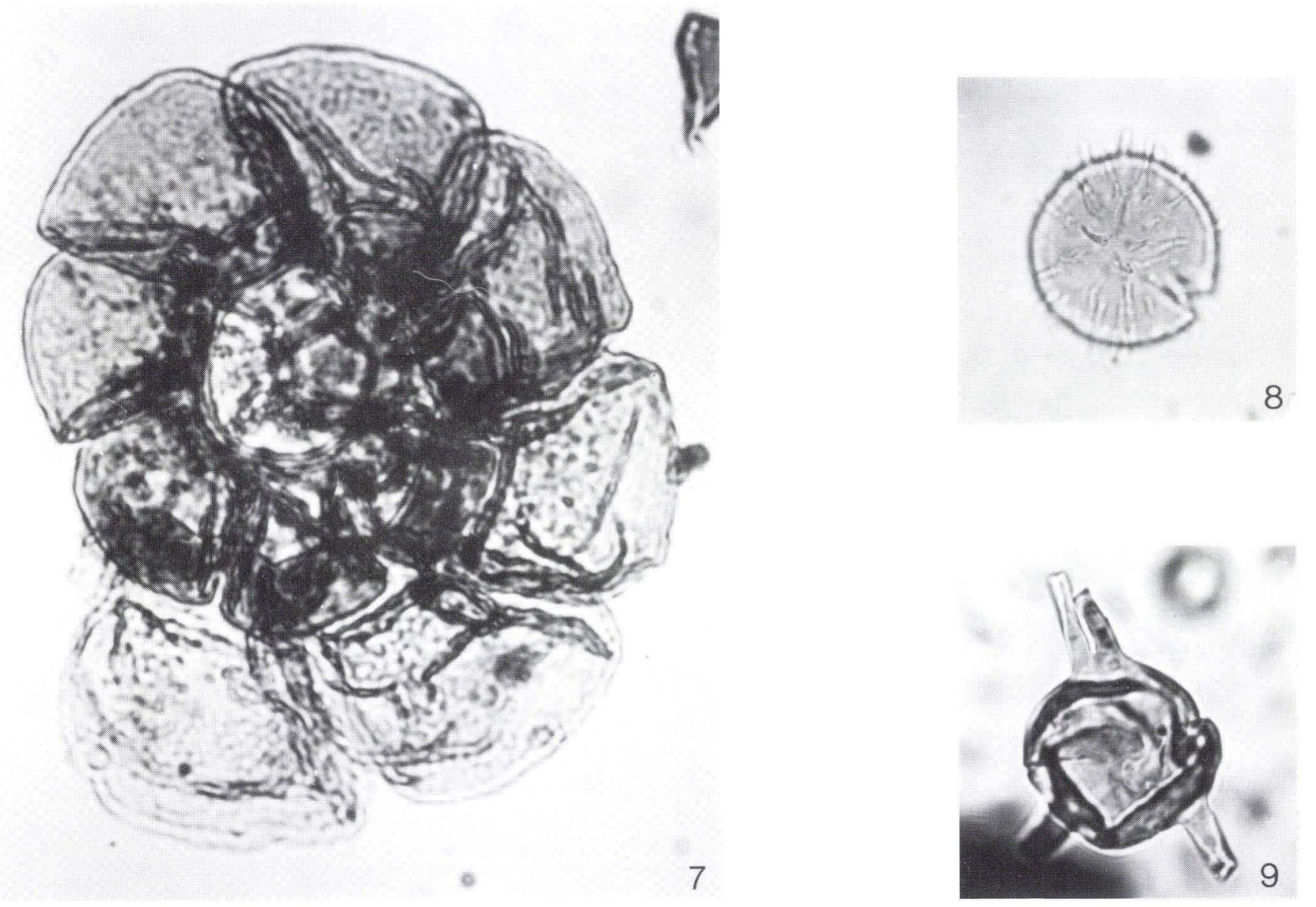


\section{PLATE 13}

Magnifications: x1000

Fig. 1. Tasmanites sp., type 1. Sample GA-50.

Fig. 2. Pterospermopsis sp. Sample GA-68.

Fig. 3. Tasmanites sp., type 2. Sample GA-54.

Fig. 4. Tasmanites sp. type 3. Sample GA-36.

Fig. 5. Nannoceratopsis gracilis Alberti. Sample GA-60.

Fig. 6. Liasidium variabile Drugg. Sample GA-36.

Fig. 7. Dapcodinium priscum Evitt. Sample GA-6.

Fig. 8. Botryococcus sp. Sample GA-65. 
Plate 13
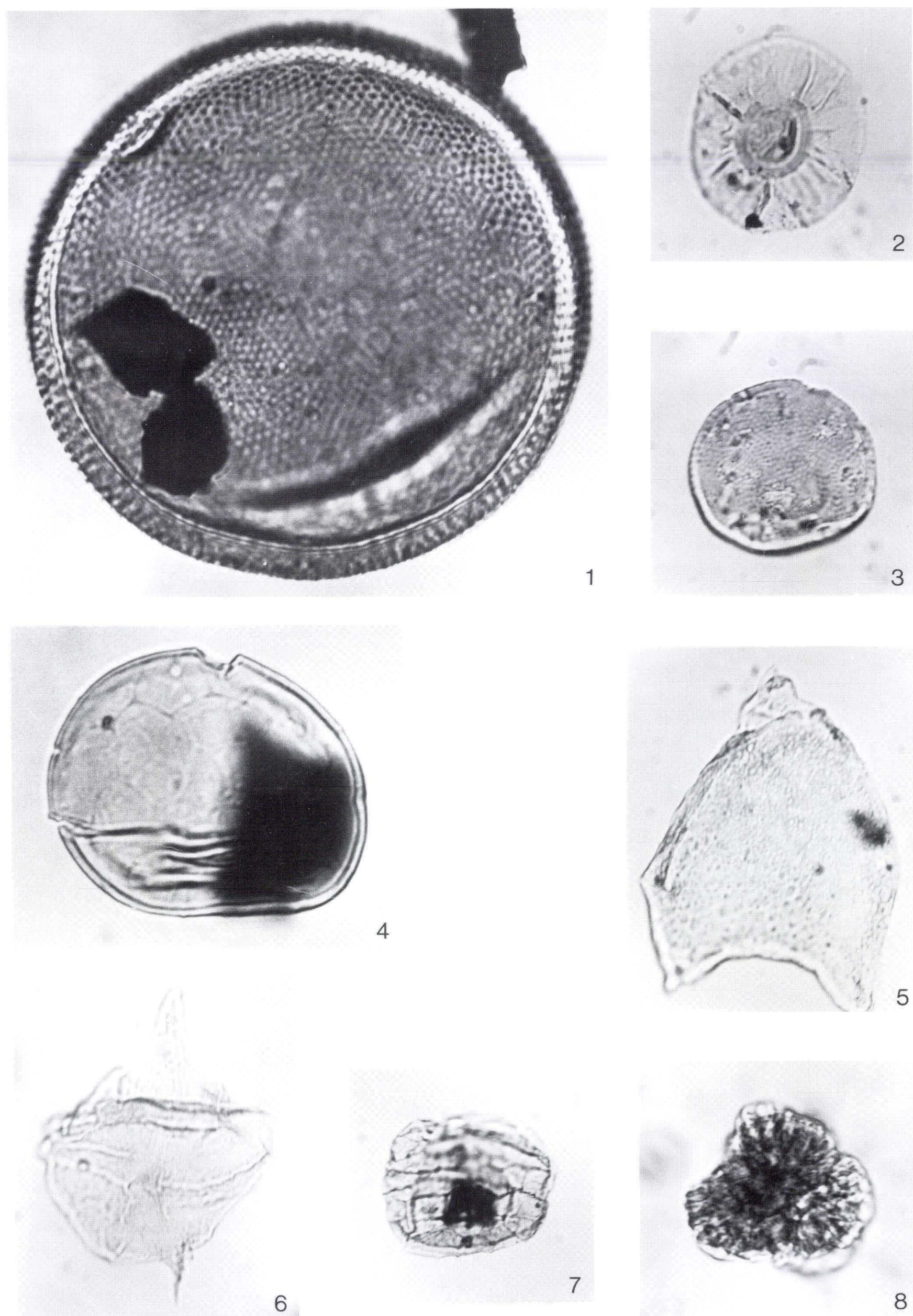


\section{PLATE 14}

Magnifications: x500

Fig. 1. Senoniasphaera jurassica (Gitmez \& Sarjeant) Lentin \& Williams. Sample GA-67. Fig. 2. Senoniasphaera jurassica (Gitmez \& Sarjeant) Lentin \& Williams. Sample GA-67.

Fig. 3. Glossodinium dimorphum Ioannides et al. Sample GA-71.

Fig. 4. Glossodinium dimorphum Ioannides et al. Sample GA-71.

Fig. 5. Hystrichogonyaulax pennata (Riley) Lentin \& Williams. Sample GA-67.

Fig. 6. Hystrichogonyaulax pennata (Riley) Lentin \& Williams. Sample GA-69.

Fig. 7. Cannosphaeropsis thula Davey. Sample GA-71.

Fig. 8. Same specimen as fig. 7, showing dorsal surface with archaeopyle.

Fig. 9. Gochteodinia mutabilis (Riley) Davey. Sample GA-71.

Fig. 10. Gonyaulacysta jurassica (Deflandre) Sarjeant. Sample GA-65.

Fig. 11. Tubotuberella apatela (Cookson \& Eisenack) Sarjeant. Sample GA-67.

Fig. 12. Kleithriasphaeridium porosispinum Davey. Sample GA-67.

Fig. 13. Kleithriasphaeridium porosispinum Davey. Sample GA-71.

Fig. 14. Occisucysta balia Gitmez. Sample GA-65.

Fig. 15. Ctenidodinium panneum (Norris) Lentin \& Williams. Sample GA-67. Hypocyst.

Fig. 16. Ctenidodinium panneum (Norris) Lentin \& Williams. Sample GA-71. Complete specimen.

Fig. 17. Mendicodinium groenlandicum (Pocock \& Sarjeant) Davey. Sample GA-65.

Fig. 18. Dichadogonyaulax culmula (Norris) Loeblich \& Loeblich. Sample GA-71.

Fig. 19. Dichadogonyaulax culmula (Norris) Loeblich \& Loeblich. Sample GA-71.

Fig. 20. Same specimen as fig. 19.

Fig. 21. Egmontodinium expiratum Davey. Sample GA-71.

Fig. 22. Egmontodinium expiratum Davey. Sample GA-67.

Fig. 23. Egmontodinium torynum (Cookson \& Eisenack) Davey. Sample GA-69. 

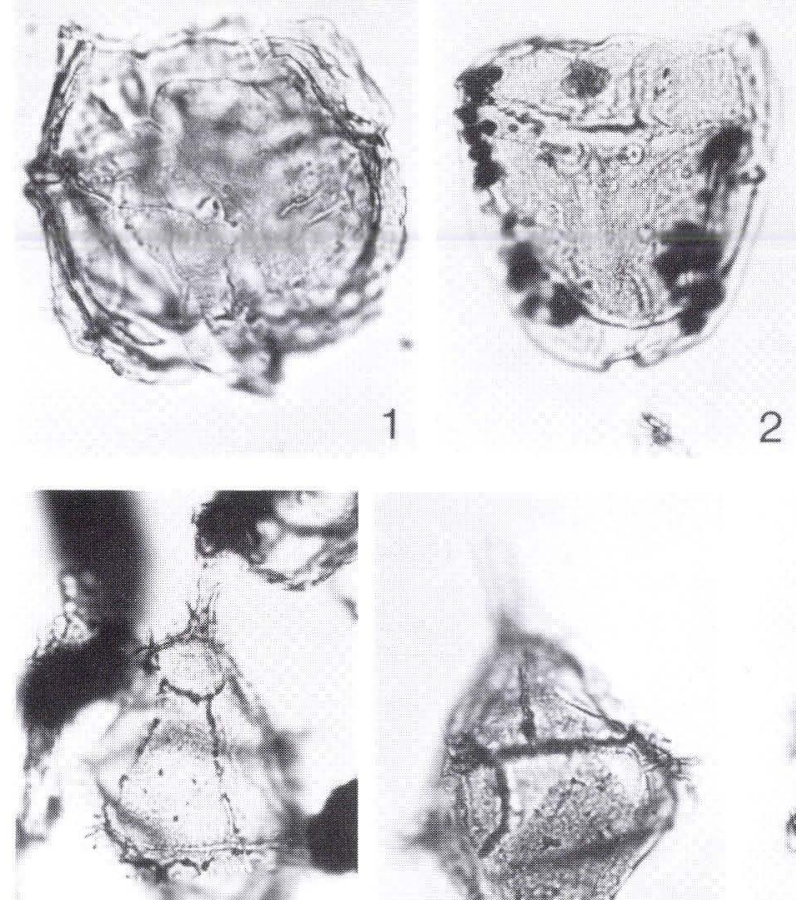

5
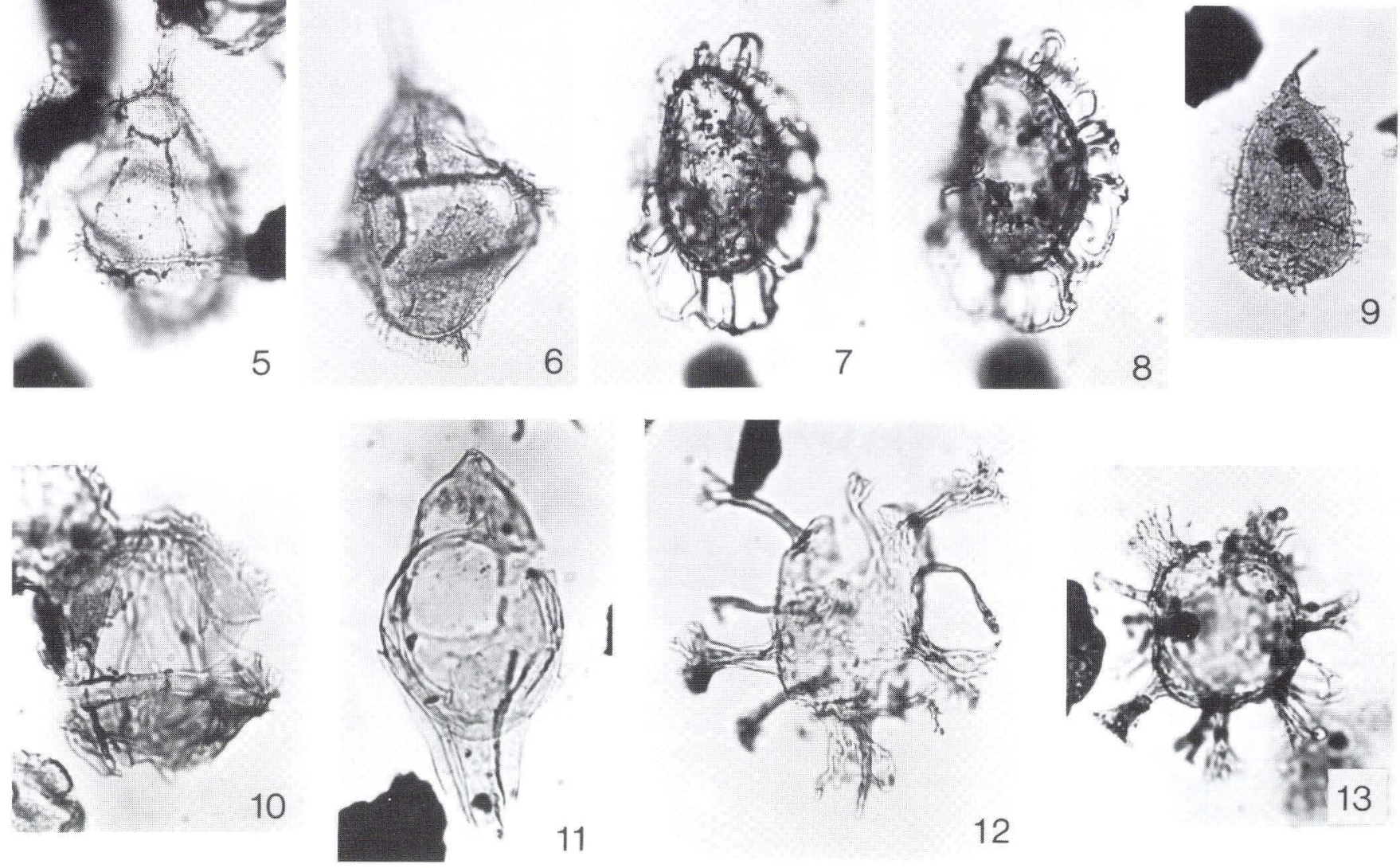

12
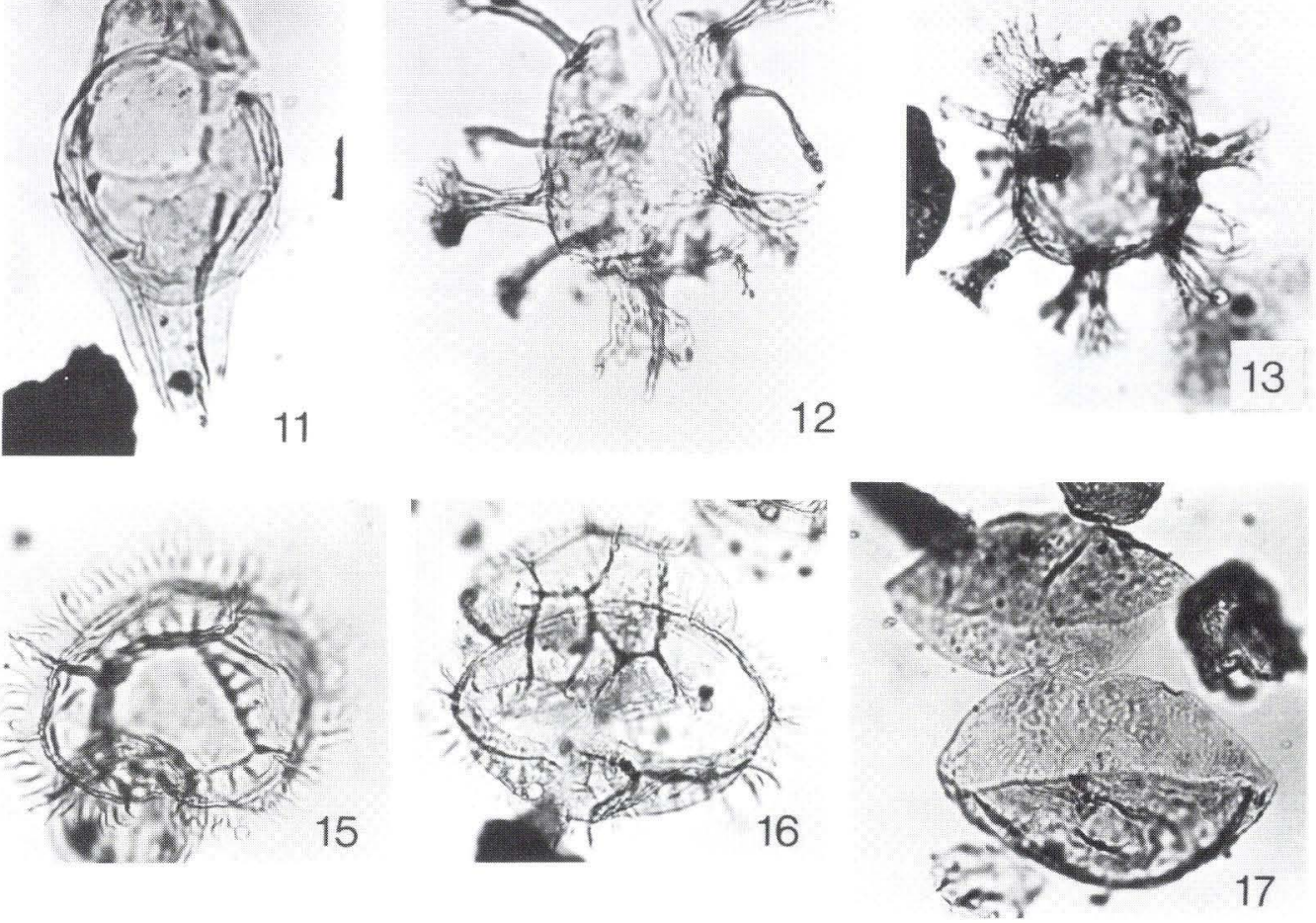
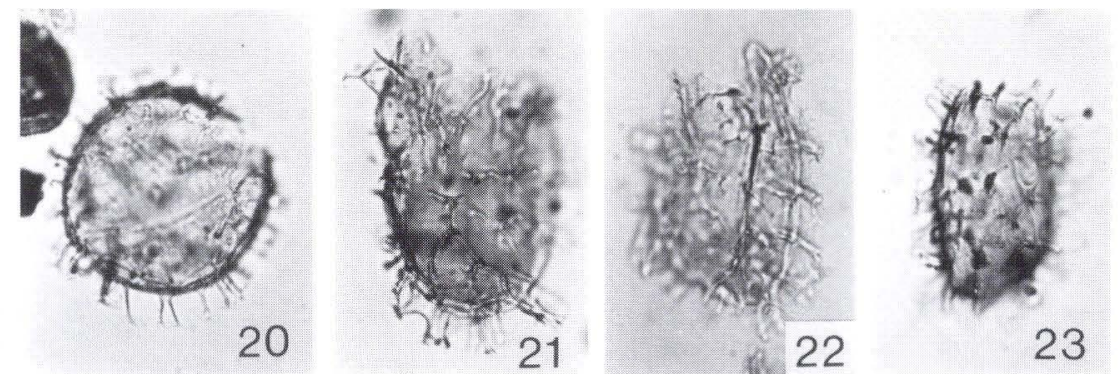


\section{Index of species}

Pollen and spores:

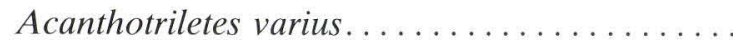

Alisporites grandis. ....................

Alisporites microsaccus ..................

Alisporites radialis .....................

Alisporites robustus ....................

Alisporites thomasii .....................

Anapiculatisporites spiniger ...............

Anapiculatisporites telephorus .............

Apiculatisporites ovalis ..................

Aratrisporites minimus .................

Araucariacites australis .................

Baculatisporites comaumensis .............

Baculatisporites oppressus.................

Baculatisporites wellmanii.................

Calamospora tener ......................

Calamospora sp.......................

Callialasporites microvelatus...............

Callialasporites segmentatus ...............

Callialasporites trilobatus .................

Cerebropollenites macroverrucosus ...........

Cerebropollenites thiergartii ................

Chasmatosporites apertus .................

Chasmatosporites elegans ................

Chasmatosporites hians ..................

Cibotiumspora jurienensis.................

Cicatricosisporites sp. ..................

Cingulizonates rhaeticus .................

Cingutriletes infrapunctus ................

Clavatipollenites hughesii ................

Conbaculatisporites mesozoicus .............

Conbaculatisporites spinosus ..............

Contignisporites problematicus..............

Corollina torosus ......................

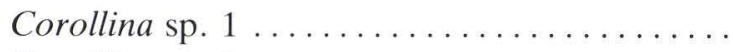

Corollina sp. $2 \ldots \ldots \ldots \ldots \ldots \ldots \ldots \ldots$

Cupressacites sp. $\ldots$

Cupressacites sp...................... p. 22

Deltoidospora crassexina ................. p. 11

Deltoidospora minor .................... p. 11

Deltoidospora toralis .................... p. 11

Densoisporites microrugulatus .............. p. 18

Densosporites fissus .................... p. 18

Eucommiidites minor................... p. 25

Eucommiidites troedssonii ................ p. 25

Exesipollenites tumulus ................... p. 23

Gleicheniidites conspiciendus .............. . p. 17

Gleicheniidites senonicus................. p. 17

Heliosporites altmarkensis.................. p. 19
Intrapunctisporis toralis.................. p. 12

Iraquispora laevigata .................. p. 15

Laevigatosporites $\mathrm{sp} . \ldots \ldots \ldots \ldots \ldots \ldots \ldots$............ p. 19

Limbosporites lundbladii ................. . p. 18

Lycopodiacidites rugulatus ................. p. 16

Cf. Lycopodiacidites .................... p. 16

Lycopodiumsporites austroclavatidites ........ $\quad$ p. 16

Lycopodiumsporites clavatoides.............. p. 16

Lycopodiumsporites semimuris ............. p. 16

Lycospora salebrosacea ................... . p. 18

Manumia variverrucata .................. p. 15

Marattisporites scabratus................. . p. 19

Monosaccate, undet..................... p. 19

Monosulcites minimus ................... p. 24

Monosulcites punctatus .................. p. 24

Monosulcites cf. punctatus ............... p. 25

Perinopollenites elatoides ................ p. 22

Pinuspollenites minimus ................. p. 20

Pinuspollenites pinoides ................. p. 20

Platyptera trilingua................... p. 17

Podocarpidites cf. biformis............... p. 20

Protopinus cf. scanicus ................... p. 20

Punctatisporites globosus ................. p. 12

Punctatisporites major................... p. 12

Quadraeculina anellaeformis .............. p. 21

Retusotriletes mesozoicus ................. p. 12

Ricciisporites tuberculatus................. . p. 24

Schismatosporites ovalis ................ p. 22

Spheripollenites psilatus................. p. 23

Spheripollenites subgranulatus ............. p. 23

Staplinisporites telatus .................. p. 17

Stereisporites antiquasporites ............. p. 13

Stereisporites cicatricosus ................ p. 13

Stereisporites cf. hauterivensis ............ p. 13

Stereisporites punctus................... p. 13

Stereisporites cf. seebergensis .............. p. 13

Stereisporites stereoides .................. p. 13

Trachysporites asper.................... p. 13

Trachysporites fuscus .................. p. 13

Trachysporites $\mathrm{cf}$. sparsus ................ p. 14

Triancoraesporites ancorae ............... p. 17

Trilobosporites sp..................... p. 17

Trisaccate undet. ..................... p. 19

Umbrosaccus keuperianus................ p. p. 22

Cf. Umbrosaccus ....................... p. 22

Uvaesporites argenteaeformis ............. p. 15

Vitreisporites pallidus................... . p. 20

Zebrasporites interscriptus ............... p. 17 
Aquatic palynomorphs:

The page-number stated for most of the dinofla-

gellate-cyst species, reter to fig. 7 , where thece
species are listed, together with thir references

and their stratigraphic ranges in the present

systematic section.

Acanthomorophitae
Botryococcus sp. .

Crenidodinium panneur

Dapcodinium priscum ........

Dingodinium tuberosum

Egmontodinum expira

Foraminiteral test-lining

Goshteodinia mutabilts

Gonyaulacysta jurass
Halosphaeropsis op

Hystrichogonyalulax cladophora

Kleithriaspheridium porasioninum .....

Liasidium variabile

Mendicodinium gre.....

Mannoceratopsis gracill

Netromorphitac
Occisucysta balia

Polygonomorphitac ....

Pteromorphitac.........
Pterospermopsis sp....

Sirmiodinium grossit ....

Systematophora sp. 1 sensu Davey 1982

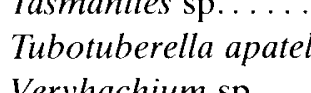

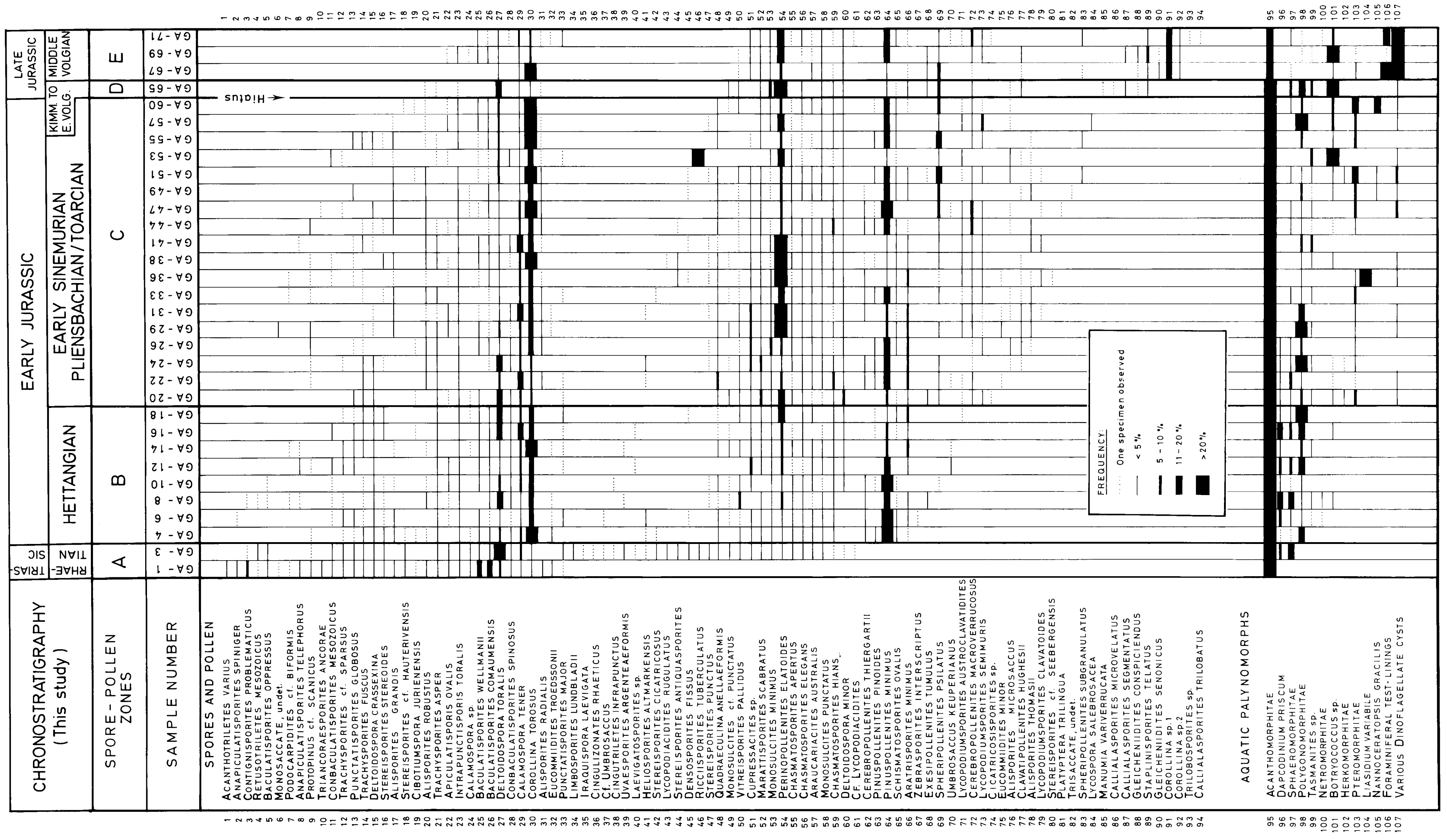

Karen Dybkjise, 1988: Palynological zonation and
sratigraphy of the Jurassic section in the Gassum No.

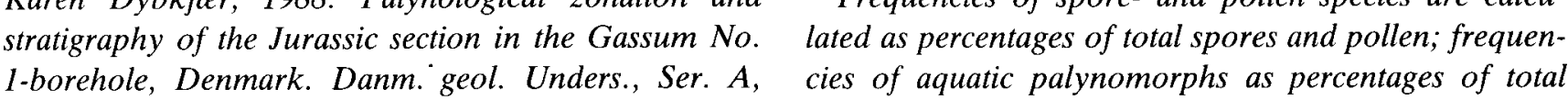


This paper presents a palynological zonation and stratigraphy of the Jurassic section of the Danish onshore borehole Gassum No. 1. The palynomorphs are treated morphosystematically and comments are added to most of the species. Interpretations of the depositional environment are made, especially concerning sea-level changes. 